Scour Assessment at Bridges From Flag Point to Million Dollar Bridge, Copper River Highway, Alaska

By Timothy P. Brabets

U.S. GEOLOGICAL SURVEY

Water-Resources Investigations Report 94-4073

Prepared in cooperation with the

ALASKA DEPARTMENT OF TRANSPORTATION

AND PUBLIC FACILITIES

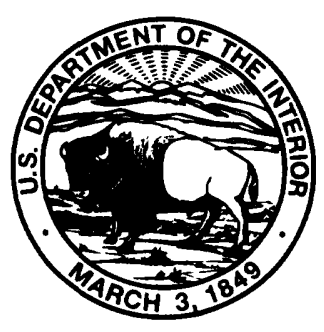

Anchorage, Alaska

1994 


\section{U.S. DEPARTMENT OF THE INTERIOR \\ BRUCE BABBITT, Secretary}

\section{U.S. GEOLOGICAL SURVEY}

Gordon P. Eaton, Director

For additional information write to:

Copies of this report may be purchased from:

District Chief

U.S. Geological Survey

4230 University Drive

Anchorage, Alaska 99508-4664
U.S. Geological Survey

Earth Science Information Center

Open-File Reports Section

Box 25286, MS 517

Denver Federal Center

Denver, Colorado 80225 


\section{CONTENTS}

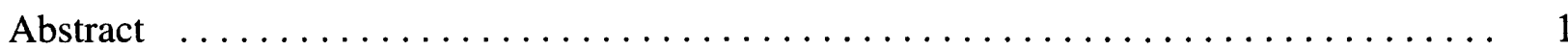

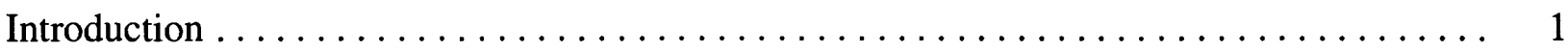

Location and description of the study area $\ldots \ldots \ldots \ldots \ldots \ldots \ldots \ldots \ldots, 2$

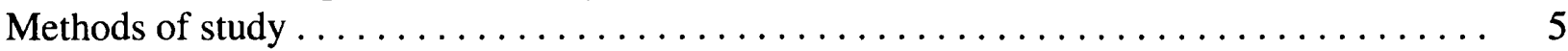

Collection and analysis of discharge and sediment data................ 6

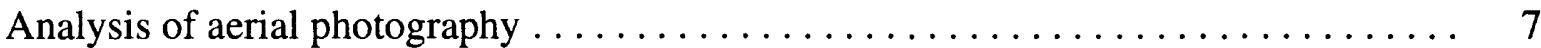

Collection and comparison of cross-sectional data . . . . . . . . . . . . . . 7

Evaluation of scour equations . . . . . . . . . . . . . . . . . . . . .

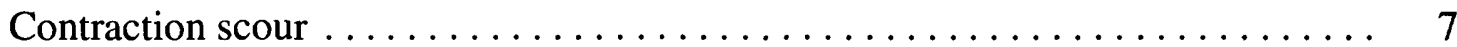

Local scour .................................... 9

Scour assessment of Copper River Highway bridges . . . . . . . . . . . . . . 12

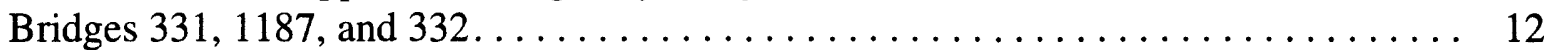

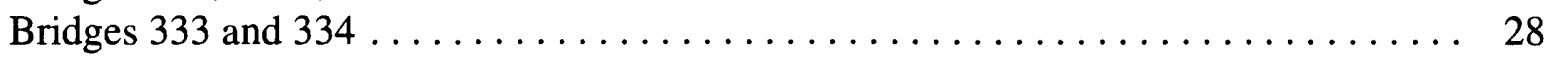

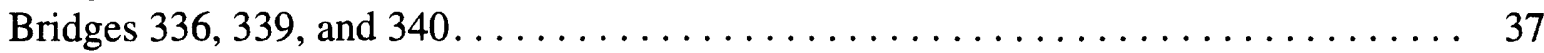

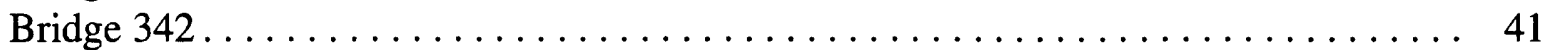

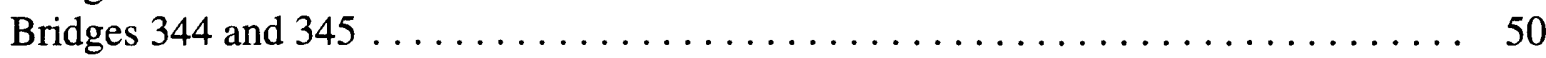

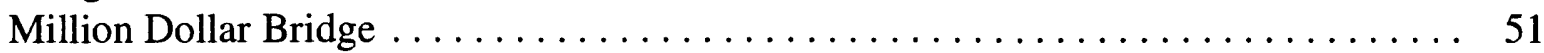

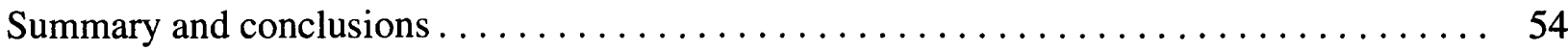

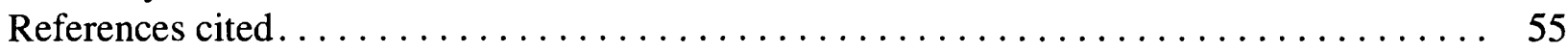

\section{FIGURES}

1. Map showing the lower Copper River delta ................... 3

2. Map showing locations of bridges along the Copper River Highway, $1991 \ldots \ldots 4$

3. Graph showing daily mean discharge of the Copper River at Million Dollar Bridge, 1992 water year ............................... 5

4. Photograph of Bridge 331 on the Copper River Highway in $1991 \ldots \ldots \ldots \ldots .13$

5. Plan view of piers constructed at Bridges 331, 1187, and 332 on the Copper River

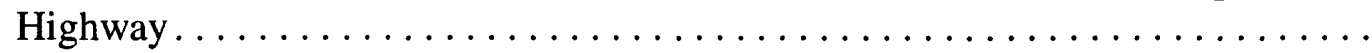

6. Graphs showing particle size distribution, median diameter, and mean diameter of bed material, Copper River at Bridges 331, 1187, and $332 \ldots \ldots \ldots \ldots \ldots 19$

7. Maps of the Copper River at Flag Point, based on aerial photographs taken

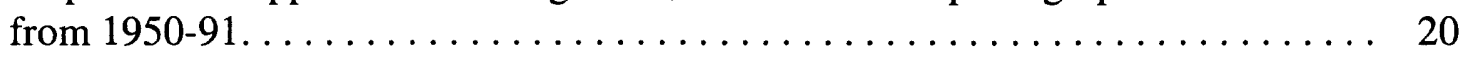

8. Approach and downstream cross sections of the Copper River at Bridge 331. . . 24

9. Approach, upstream, and downstream cross sections of the Copper River

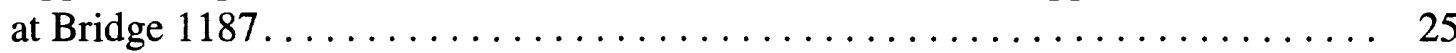

10. Upstream and downstream cross sections of the Copper River at Bridge 332 . . . 27

11. Photograph of Bridge 333 on the Copper River Highway in 1991.......... 29

12. Diagram showing top and side views of piers at Bridges 333 and 334 on

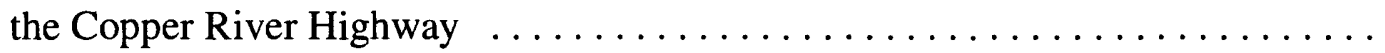

13. Maps of the Copper River near Long Island, based on aerial photographs taken

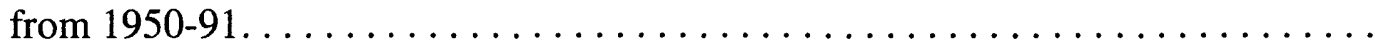


14-19. Cross sections of the Copper River, downstream side of:

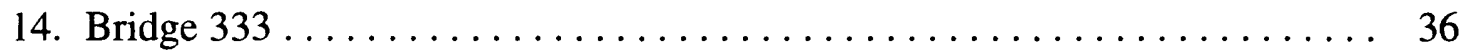

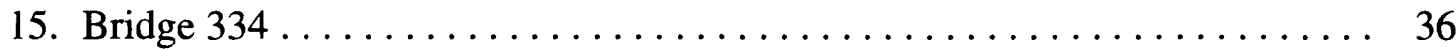

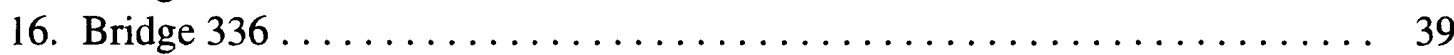

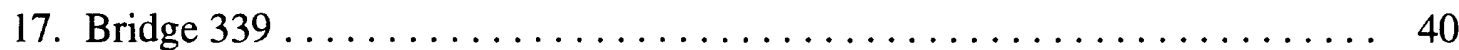

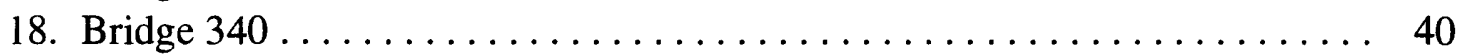

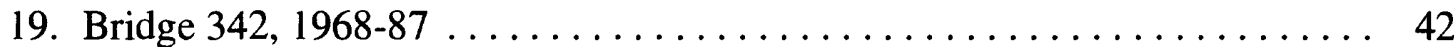

20. Photograph of Bridge 342 on the Copper River Highway, looking downstream,

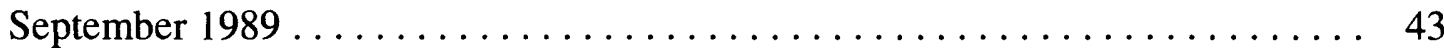

21. Cross sections of the Copper River, downstream side of Bridge 342, $1989-90$ and $1991-92 \ldots \ldots \ldots \ldots \ldots \ldots \ldots \ldots \ldots \ldots \ldots \ldots . \ldots \ldots$

22. Photographs of Bridge 342 on the Copper River Highway looking upstream and downstream, September 1991and September $1992 \ldots \ldots \ldots \ldots \ldots \ldots \ldots 45$

23. Graph showing particle size distribution, median diameter, and mean diameter of bed material, Copper River at Bridge $342 \ldots \ldots \ldots \ldots \ldots \ldots \ldots \ldots 47$

24. Cross sections of the Copper River, downstream side of Bridge 344. . . . . . . 50

25. Cross sections of the Copper River, downstream side of Bridge 345....... 51

26. Photograph of Million Dollar Bridge on the Copper River Highway, 1991.... . . 52

27. Cross sections of Copper River, downstream side of the Million Dollar Bridge ... 54

\section{TABLES}

1. Discharge of the Copper River at Bridges 331, 1187, 332, and the Million Dollar Bridge .................................... 15

2. Suspended-sediment data for the Copper River at Bridges 331, 1187, and $332 \ldots \ldots 16$

3. Suspended-sediment data and particle-size analyses for the Copper River

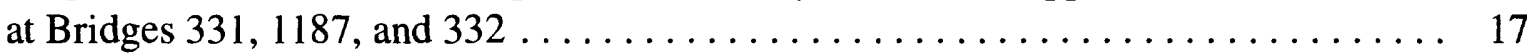

4. Bedload data for the Copper River at Bridges 331, 1187, and 332 .......... 18

5. Measured and predicted mean depth of flow at Bridges 331 and 1187 on the Copper River Highway, May $1992 \ldots \ldots \ldots \ldots \ldots \ldots \ldots \ldots \ldots \ldots . \ldots \ldots$

6. Measured and predicted local scour at Bridges 331 and 1187 on the Copper River Highway . . . . . . . . . . . . . . . . . . . . . 28

7. Discharge of the Copper River at Bridges 333, 334, and the Million Dollar Bridge. . . 30

8. Suspended-sediment data for the Copper River at Bridges 333 and $334 \ldots \ldots \ldots \ldots .31$

9. Discharge of the Copper River at Bridges 339, 340, and the Million Dollar Bridge. . . 37

10. Suspended sediment data for the Copper River at Bridges 339 and $340 \ldots \ldots \ldots \ldots . .38$

11. Ranked peak discharges of the Copper River near Chitina, 1951-90 . . . . . . . . . 41

12. Changes in mean bed elevation of the Copper River at Bridge 342, 1968-92 ....... 43

13. Discharge, suspended-sediment, and bedload data of the Copper River at Bridge 342 . 48

14. Suspended-sediment data and particle-size analyses for the Copper River at

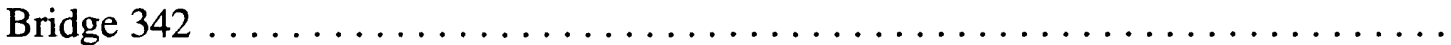

15. Suspended-sediment data and particle-size analyses for the Copper River at Million Dollar Bridge................................ 


\begin{tabular}{rll}
\hline Multiply & By & To obtain \\
\hline inch (in.) & 25.4 & millimeter \\
foot $(\mathrm{ft})$ & 0.3048 & meter \\
mile $(\mathrm{mi})$ & 1.609 & kilometer \\
square $\mathrm{mile}\left(\mathrm{mi}^{2}\right)$ & 2.590 & square kilometer \\
foot per second $(\mathrm{ft} / \mathrm{s})$ & 0.3048 & meter per second \\
foot per second squared $\left(\mathrm{ft} / \mathrm{s}^{2}\right)$ & 0.3048 & meter per second squared \\
foot squared per second $\left(\mathrm{ft}^{2} / \mathrm{s}\right)$ & 0.0929 & meter squared per second \\
cubic foot per second $\left(\mathrm{ft}^{3} / \mathrm{s}\right)$ & 0.02832 & cubic meter per second \\
ton per day $(\mathrm{ton} / \mathrm{d})$ & 0.9072 & megagram per day \\
\hline
\end{tabular}

Abbreviations used in this report:

$\mathrm{mg} / \mathrm{L}$, milligram per liter

$\mathrm{mm}$, millimeter

\section{Sea level:}

In this report, "sea level" refers to the National Geodetic Vertical Datum of 1929 (NGVD of 1929), a geodetic datum derived from a general adjustment of the first-order nets of both the United States and Canada, formerly called Sea Level Datum of 1929. 


\title{
Scour Assessment at Bridges From Flag Point to Million Dollar Bridge, Copper River Highway, Alaska
}

\author{
By Timothy P. Brabets
}

\section{Abstract}

Twelve bridges are located along the Copper River Highway from Flag Point (Mile 27) to the Million Dollar Bridge (Mile 48). These bridges cross all or parts of the Copper River. Channel scour at these bridges was assessed by collecting and analyzing discharge and sediment data, analyzing aerial photography for eight different years, surveying and comparing cross sections, and utilizing scour equations.

Between 1968 and 1992, scour occurring at Bridge 331 has formed two distinct channels at the bridge. The channel at Bridge 1187 has remained relatively unchanged between 1968 and 1992. During this same time period, the channel at Bridge 332 appears to have gradually filled. However, during the 1992 runoff season, the channel at this bridge scoured significantly, probably because of its unstable nature. The most significant scour has occurred at Bridge 342. A highwater period in 1981 probably shifted much of the flow of the Copper River through this bridge. As a result, severe contraction scour occurred which required major repairs to the bridge. During 1991 and 1992, the approach channel to Bridge 342 has been migrating, causing scour in the left side of the channel. Bed material at the Million Dollar Bridge consists of hard unweathered boulders nested in dense gravel. Because of this type of erosion-resistant material, no significant scour has occurred at this site.

Equations that predict the mean depth of contracted scour overestimated the mean depth of scour at Bridge 331 by 2.6 to $5.0 \mathrm{ft}$, but were within $1.0 \mathrm{ft}$ of the mean depth of scour for Bridge 1187. The local scour equations generally overestimated local scour at both Bridge 331 and Bridge 1187. The accuracy of some equations was probably affected because water velocities could not be obtained upstream from the piers.

\section{INTRODUCTION}

In designing bridges, spur dikes, or other structures in alluvial channels, an accurate assessment of the potential for scour is essential. For example, overestimating scour could lead to the overdesign of a structure, resulting in higher construction costs. Underestimating scour could lead to the design of a structure that would suffer major damage during a large flood.

Channel scour around or near bridges can occur as the result of one of three processes. Contraction scour occurs when the flow area is decreased, causing an increase in average velocity and shear stress in the vicinity of the bridge. If the shear stress at the bed is high enough, the bed material will begin to move. Local scour results from the action of vortices around a pier, which accelerates the flow of water around the pier, removing bed materials from the base region. The longterm aggradation or degradation of a stream channel throughout a relatively long reach may also lead to scour or undermining of bridge piers. 
Estimating potential scour accurately is a complex task for several reasons. Scour may occur as a result of a combination of the three processes and it is difficult to distinguish which process is the most dominant. The position of the thalweg of a river may change with discharge, and thus scour may occur at different locations. Most of the equations that have been developed for determining local scour are based on laboratory experiments and have not been field verified. In many instances, it is difficult to obtain the appropriate field data.

In April 1991, under a cooperative agreement with the State of Alaska, Department of Transportation and Public Facilities (ADOT\&PF), the U.S. Geological Survey (USGS) began a study of the geomorphology of the lower Copper River (fig. 1). This study area encompasses the Copper River Highway from Flag Point (mile 27) to the Million Dollar Bridge (mile 48). It includes 12 bridges located along the highway (fig. 2), some of which have experienced scour problems both at piers and at abutments. One aspect of this study has been the assessment of scour characteristics at these bridges, specifically to determine (1) if scour has occurred at bridges along the highway and (2) which hydraulic or geomorphic process or processes are the cause of the scour. This report describes and summarizes the findings.

\section{LOCATION AND DESCRIPTION OF THE STUDY AREA}

The lower Copper River, including the Copper River Delta (fig. 1) is a complex and dynamic river system. Near its mouth, the river drains a basin approximately $24,000 \mathrm{mi}^{2}$ in size, which is the fourth largest basin in Alaska. The average discharge of the Copper River at the Million Dollar Bridge is about 63,000 $\mathrm{ft}^{3} / \mathrm{s}$ : minimum flows occur during winter months and maximum flows occur during summer months (fig. 3). During late May or early June, a high-flow period begins, reflecting snowmelt runoff. Rainfall causes this high-flow period to continue from mid-July through August. Glacier-dammed Van Cleve Lake (fig. 1) breaks out approximately every 5 years, causing a sharp and rapid increase in flow in the Copper River. The river transports large quantities of sediment from glaciers and from erodible banks of the Copper River Lowlands located upstream from Miles Lake (fig. 1). Distributary channels in the approximately 300square-mile delta constantly scour and fill, causing lateral channel migration.

The Copper River Highway was built on the original right of way of the Copper River and Northwestern Railroad. Built in 1908-11 to haul copper ore from the Kennecott Mine in interior Alaska to Cordova, the railroad ceased operation in 1938. From 1938 to about 1962, the railbed was gradually converted to the Copper River Highway, beginning at Cordova and extending several miles past the Million Dollar Bridge. When the Alaska earthquake of 1964 struck, most, if not all, of the bridges along the highway were damaged beyond repair and work on extending the road was halted.

Reconstruction of the bridges between Flag Point and the Million Dollar Bridge began in 1970. At some locations along the highway where the Copper River had shifted away from the road, bridges were not rebuilt, but rather the bridge opening was filled in. The north span of the Million Dollar Bridge that collapsed during the 1964 earthquake was not raised, but a replacement pier was constructed to stabilize the remaining spans. When reconstruction was completed in 1978, 12 bridges (fig. 2) were located between Flag Point and the Million Dollar Bridge. 

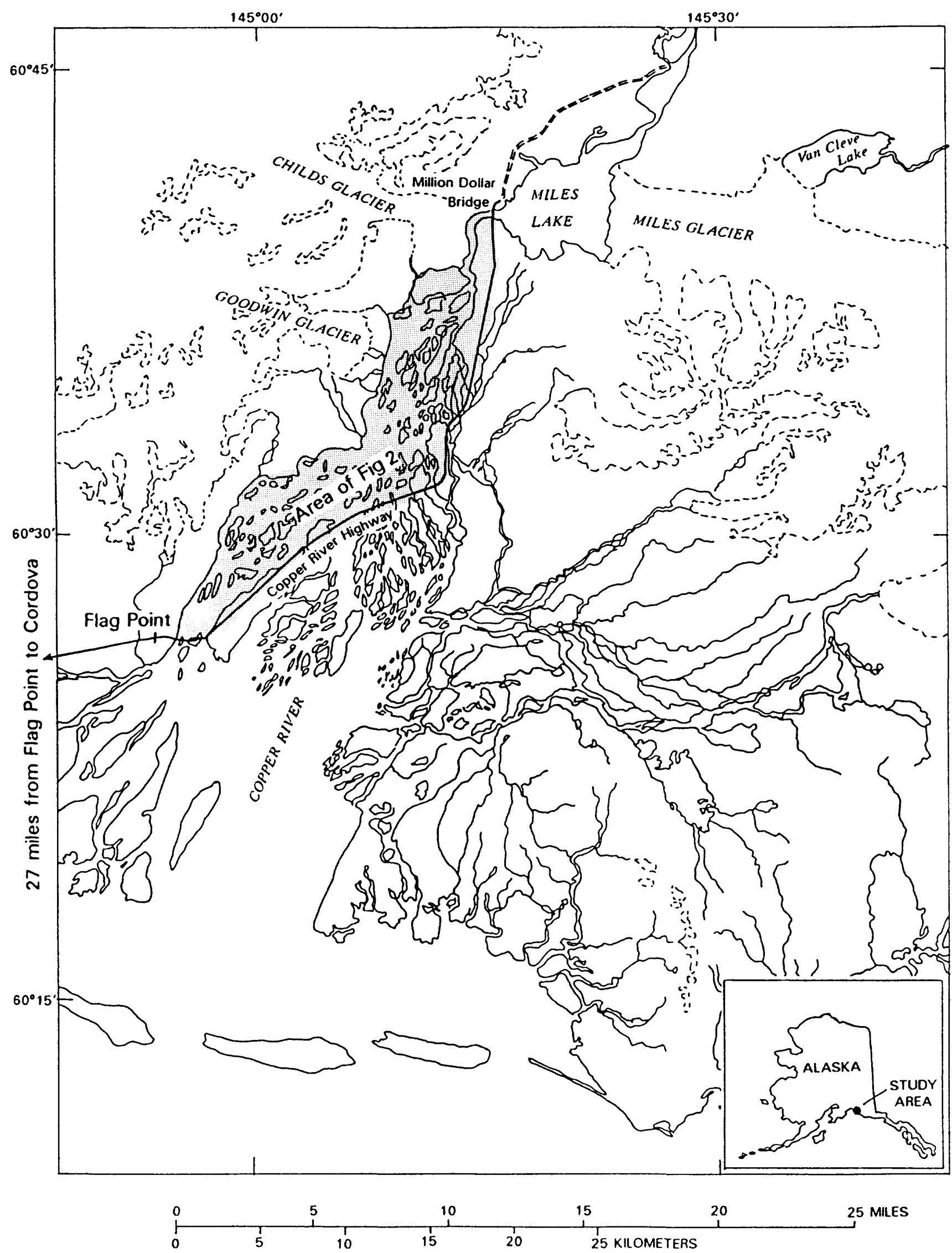

Figure 1. The lower Copper River Delta. 


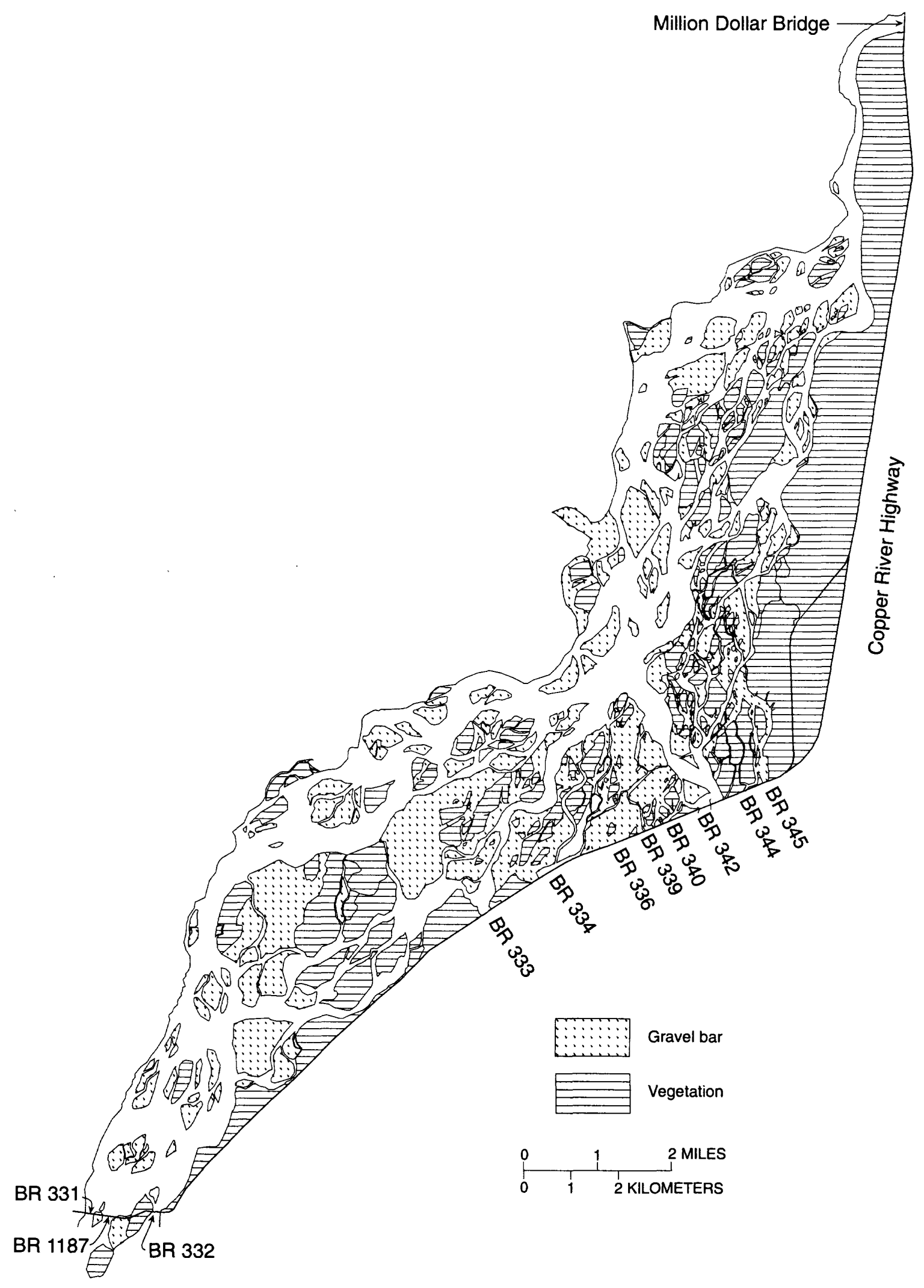

Figure 2. Locations of bridges (BR) along the Copper River Highway, 1991. 


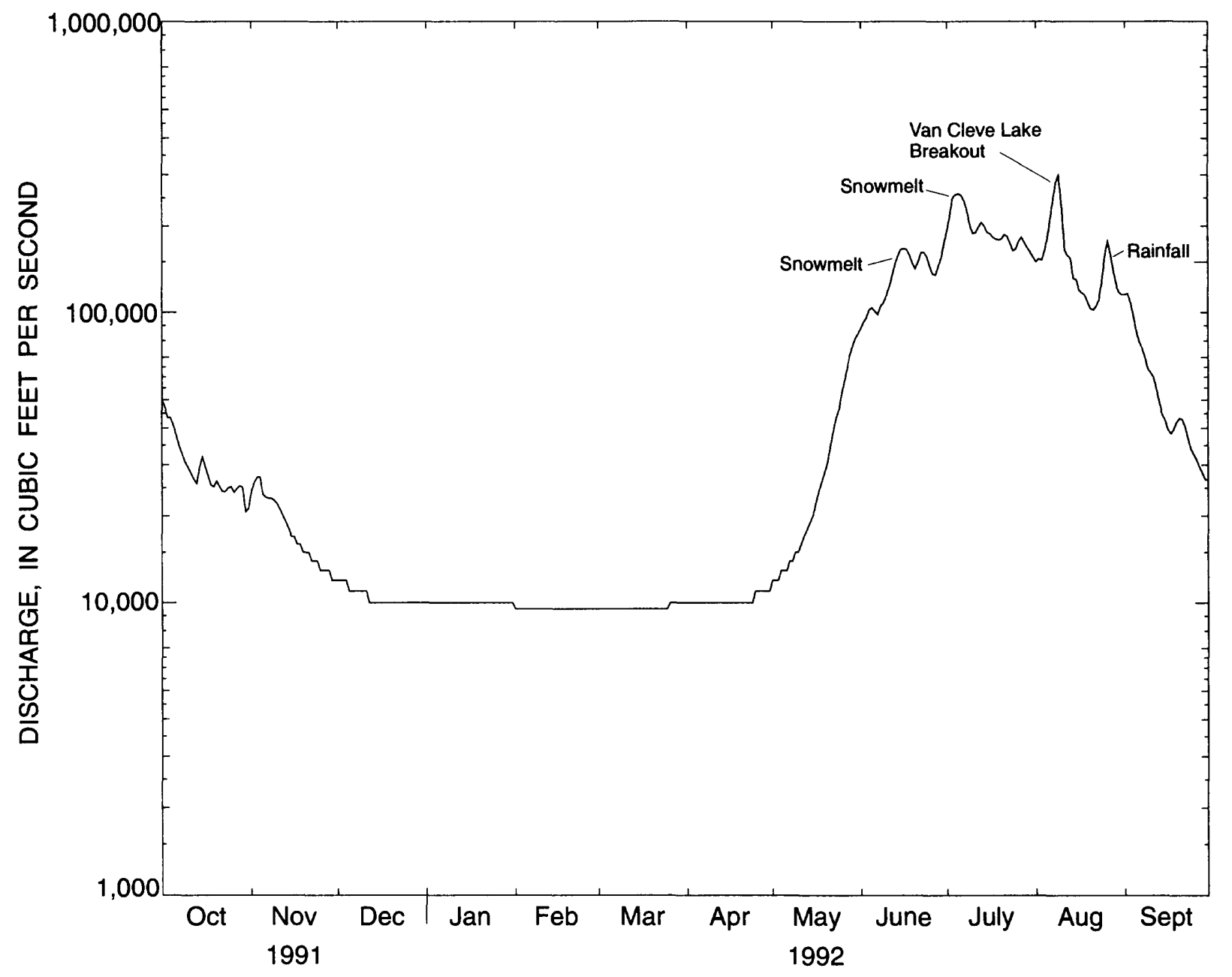

Figure 3. Daily mean discharge of the Copper River at Million Dollar Bridge, 1992 water year.

\section{METHODS OF STUDY}

Many techniques have been developed for assessing scour at bridges. One technique involves instrumenting a particular pier and then continuously monitoring the scour at the pier (Richardson and Price, 1993). Mathematical models have been developed to predict scour (Molinas and Santoro, 1989) and geophysical techniques have been used to document infilling of local scour holes (Gorin and Haeni, 1989). A considerable amount of work has also been done in laboratories to develop scour equations (Richardson and Richardson, 1989).

During this study, contraction scour, local scour, and long-term aggradation/degradation of stream channels at bridge sites along the Copper River Highway were evaluated using four different methods: (1) collecting and analyzing discharge and sediment data, (2) analyzing aerial photography, (3) collecting and comparing cross-section data, and (4) evaluating scour equations. It was advantageous to use more than one method, because one particular method might be better suited for defining one scour type than another type. 


\section{Collection and Analysis of Discharge and Sediment Data}

Discharge is one of the most important variables that influences channel form (Lane, 1957). At a given cross section, the width, depth, and velocity of a stream will increase with discharge and the alluvial channel will adjust in size to transmit the discharge (Leopold and Maddock, 1953). Thus, the fluctuations in flow may be a significant factor in the development of channel patterns.

The USGS has collected streamflow information at the Million Dollar Bridge (gaging station No. 15214000) since 1988. From 1950 to 1990, streamflow information was also collected at the Copper River near Chitina (gaging station No. 15212000), about 65 mi upstream from the Million Dollar Bridge. The flow information from these two stations was used in three applications. First, during the 1991 and 1992 open-water periods, discharge measurements were made approximately every 2 weeks at all bridges except at the Million Dollar Bridge. Because the channel is considered to be stable at the Million Dollar Bridge, discharge measurements were made approximately every 6 weeks at this site. The discharge at each bridge was then correlated with the flow at the Million Dollar Bridge to determine the percentage of total flow past specific bridges downstream. This approach was judged to be satisfactory because the tributary inflow to the Copper River is insignificant between the Million Dollar Bridge and the remaining bridges along the highway. Changes in the percentage of total flow past a particular bridge could indicate possible shifts of the channel. In the second application, the concurrent daily discharges available from the Chitina gaging station and the Million Dollar Bridge gaging station from June 1988 to September 1990 were used to develop a relation to estimate the flow at the Million Dollar Bridge from the flow at Chitina. Discharges were then estimated for the dates when aerial photography was taken to determine whether the photography was obtained during a low- or high-flow period. In the third application, flood-peak information from Chitina was used to determine when high flows may have occurred prior to 1988 in the lower Copper River. Information about these highflow periods was compared with aerial photography and ADOT\&PF maintenance files to determine if channel changes may have occurred during these periods.

Another important variable that influences channel form is sediment. Knowledge of the quantity and size of suspended-sediment that is transported is necessary to determine characteristics of deposition and scour. Similarly, knowing the size of bed material and the size and quantity of sediment being moved as bedload may indicate if a channel is stable or unstable.

Suspended-sediment samples were also collected concurrently with discharge measurements using the techniques outlined by Edwards and Glysson (1988). At five bridges, bedload samples were collected using a sampler (Helley and Smith, 1971) designed for collecting coarse material ( 0.062 to $76.2 \mathrm{~mm}$ ) and using techniques outlined by Emmett (1979). Bed material samples were collected at Bridges 331, 1187, 332, and 342 in 1992, because relatively high discharges were measured at these sites. Samples were collected during a low-water period from exposed sand and gravel bars downstream from these bridges. 


\section{Analysis of Aerial Photography}

Aerial photography of the study area is available for 8 years: $1950,1965,1971,1974,1978$, 1982 , 1985, and 1991. This photography was digitized and entered into a Geographical Information System (GIS) database. The GIS of the study area provided a means to compare the photography easily and at a common scale. For each bridge site, the photography was analyzed to determine if any significant channel migration had occurred or if other notable features, such as sandbars, had formed upstream from the particular bridge. This information does not necessarily indicate that contraction or local scour did occur or would occur at a particular bridge. Instead, the information serves as an indicator of general channel instability and provides supporting evidence in documenting long-term aggradation or degradation of a stream channel.

\section{Collection and Comparison of Cross-Sectional Data}

A common datum was established in the study area in 1991 by use of Global Positioning System (GPS) techniques (Brabets, 1992, 1993). At each bridge, at least one monument was established. When discharge measurements were made, the water-surface elevation was referenced to this datum. In this way, streambed elevations could be determined from depth soundings. At bridge sites where no flow was present, the ground elevation was surveyed in 1993. By comparing the cross sections, the quantity of scour or fill in a given year could be determined.

In addition to the survey data collected in 1991 and 1992, survey data were also available from ADOT\&PF files. Locations that had known elevations in the as-built bridge plans were resurveyed in 1991. The datum from the as-built bridge plans was then adjusted to the 1991 datum. Because the as-built plan for each bridge included streambed elevations determined in 1968, longterm trends in scour or fill could be detected at each bridge by comparing the mean bed elevation for each year. In determining the mean bed elevation at a bridge, the same channel width was used for all years.

\section{Evaluation of Scour Equations}

Equations have been developed that predict contraction scour and local scour. Many of the equations were empirically derived and have not been tested with actual field data. Because a considerable amount of data has been collected in the study area, an effort was made to determine if any of the following equations would provide reasonable estimates of scour. If so, the equations could be used in future studies.

\section{Contraction Scour}

The most widely used equation for predicting contraction scour was developed by Laursen (1962). This equation was based on the principle of continuity using discharge and sediment transport formulas and is written as: 


$$
\frac{d_{2}}{d_{1}}=\left(\frac{Q_{2}}{Q_{1}}\right)^{6 / 7}\left(\frac{b_{1}}{b_{2}}\right)^{K_{1}}\left(\frac{n_{2}}{n_{1}}\right)^{K_{2}}
$$

where $d_{1}$ is the average depth in the main or uncontracted channel, in feet;

$d_{2}$ is the average depth in the contracted section, in feet;

$Q_{1}$ is the flow in the main or uncontracted channel, in cubic feet per second;

$Q_{2}$ is the flow in the contracted section, in cubic feet per second;

$b_{1}$ is the bottom width in the uncontracted section, in feet;

$b_{2}$ is the bottom width in the contracted section, in feet;

$n_{1}$ is Manning's $n$ for uncontracted section;

$n_{2}$ is Manning's $n$ for contracted section;

$K_{1}$ is $0.59,0.64$, or 0.69 depending on the type of bed material transported; and

$K_{2}$ is $0.066,0.21$, or 0.37 depending on the type of bed material transported.

In applying Laursen's equation in this study, no significant overbank flow occurs and thus $n_{1}$ is equal to $n_{2}$. Also, discharge in the uncontracted section, $Q_{1}$, was equal to discharge in the contracted section, $Q_{2}$. This simplified the equation to:

$$
\frac{d_{2}}{d_{1}}=\left(\frac{b_{1}}{b_{2}}\right)^{K_{1}}
$$

On the basis of previous work by Norman (1975) for Alaska streams, a value of 0.59 for $K_{1}$ was found to give the best results and used for this study. Norman also tested contraction scour equations developed by Komura (1966) and Straub (1940). These contraction scour equations were also tested.

The Komura equation takes the form:

$$
\frac{d_{2}}{d_{1}}=\left(\frac{b_{1}}{b_{2}}\right)^{0.86}
$$

The Straub equation takes the form:

$$
\frac{d_{2}}{d_{1}}=\left(\frac{b_{1}}{b_{2}}\right)^{0.64}
$$

Note that these contraction scour equations compute a ratio of flow depth in the contracted section $\left(d_{2}\right)$ to that in the uncontracted section $\left(d_{1}\right)$. The average depth of contraction scour is then $d_{2}$ minus $d_{1}$. 


\section{Local Scour}

Many equations for determining local pier scour have been developed, primarily from laboratory experiments. These equations usually take three forms (McIntosh, 1989):

$$
\begin{gathered}
\frac{d_{s}}{b}=K\left(\frac{y_{o}}{b}\right)^{n} \\
\frac{d_{s}}{b}=K\left(\frac{y_{o}}{b}\right)^{n}(F r)^{p} \\
\frac{d_{s}}{b}=K
\end{gathered}
$$

where $d_{\mathrm{s}}$ is scour depth, in feet;

$b$ is pier width, in feet;

$K$ is multiplier that incorporates pier geometry and orientation;

$y_{0}$ is depth of approach flow, in feet;

$F r$ is Froude number $=\frac{V}{\left(g y_{o}\right)^{0.5}}$;

$V$ is velocity, in feet per second, of the approach flow;

$g$ is acceleration due to gravity $=32.2 \mathrm{ft} / \mathrm{s}^{2}$;

$n$ is a factor relating scour to the flow depth of the stream; and

$p$ is a factor ranging from 0.2 to 0.67 .

There are several limitations in assessing the applicability of local scour equations to specific field sites. One limiting factor is the selection of the channel bed reference surface from which scour depth is measured. A review of the literature (Norman, 1975; Jarrett and Boyle, 1986; and Blodgett, 1989) reveals many definitions of the reference surface. Mean bed elevation, water-surface elevation, concurrent ambient bed elevation, maximum observed bed elevation, and depth below highest thalweg elevation have all been used to define the reference surface. Depending on the selection of a reference surface, measured scour depths have been found to vary by as much as 100 percent (Landers and Mueller, 1993). Comparisons of the measured scour with the computed scour are thus compounded.

Another limitation in assessing local scour equations is the difficulty in obtaining the appropriate field data. For example, some equations require the velocity and depth upstream from the pier. In this study, it was not possible to collect these data. Thus, if estimates of these variables are not accurate, the corresponding accuracy of the predicted scour may be affected.

In selecting the local scour equations, only those equations which estimate scour depth from the bed elevation were used. Some equations estimate the scoured depth from the water surface, but because water-surface elevations fluctuate significantly at these bridges, no definitive water-surface elevation could be determined. Thus, this type of local scour equation was not tested. The selected scour equations were tested at two bridges. The equations were obtained from the National Cooperative Highway Research Program (1970), Anderson (1974), Hopkins and others (1980), Norman (1975), and Woo and Fan (1989). 
Bata (1960):

$$
D=10\left(\frac{V^{2}}{g}-3 d_{\mathrm{m}}\right)
$$

where $D$ is scour depth measured from mean bed elevation, in feet;

$d_{\mathrm{m}}$ is the mean diameter of bed material, in feet.

Breusers (1965):

$$
D_{\max \mathrm{e}}=1.4 b^{*}
$$

where $D_{\max }$ is maximum scour depth at equilibrium measured from ambient bed elevation, in feet; $b^{*}$ is width of the pier projected on a plane normal to undisturbed flow, in feet.

Carstens (1966):

$$
\frac{D_{e}}{b}=0.546\left[\frac{\left(N_{s}^{2}-1.64\right)}{\left(N_{s}^{2}-5.02\right)}\right]^{0.83}
$$

where $D_{e}$ is scour depth at equilibrium measured from mean bed elevation, in feet; $N_{s}$ is the sediment number $=\frac{V}{\left[(s-1) g d_{\mathrm{m}}\right]^{0.5}} ;$

where $s$ is specific gravity of the sand $=2.65$.

Chitale (1962):

$$
\frac{D}{y_{o}}=6.65 F r-5.49 F r^{2}-0.5
$$


Froehlich (1988):

$$
\frac{d s}{b}=0.32 \phi\left(\frac{b^{\prime}}{b}\right)^{0.62}\left(\frac{y_{o}}{b}\right)^{0.46} F^{0.20}\left(\frac{b}{d_{50}}\right)^{0.08}+b
$$

where $\phi$ is pier nose shape: 1.3 for a square-nosed pier;

1.0 for a round-nosed pier;

0.7 for a sharp-nosed pier;

$b^{\prime}$ is $(b \operatorname{Cos} \alpha+l \operatorname{Sin} \alpha)$, the pier width, in feet, projected normal to the approach flow; where $\alpha$ is approach angle ( 0 for aligned flow);

$l$ is pier length, in feet; and

$d_{50}$ is median diameter of bed material, in feet.

Laursen $(1958,1962)$ :

$$
D=1.5 b^{0.7} y_{o}^{0.3}
$$

Neill (1964):

$$
\frac{d s}{b}=1.5 k\left(\frac{y_{o}}{b}\right)^{0.3}
$$

where $\quad k$ is 1 to 7 for angle of attack.

Norman (1975):

$$
\begin{aligned}
& d_{\mathrm{s}}=3 \mathrm{~b}^{0.8} \text { for bed material of medium silts to fine sands } \\
& \left(\mathrm{d}_{50}=0.03-0.25 \mathrm{~mm}\right) \text {, } \\
& d_{\mathrm{s}}=2 \mathrm{~b}^{0.8} \text { for bed material of medium sands to fine gravels } \\
& \left(\mathrm{d}_{50}=0.25-8 \mathrm{~mm}\right) \text {, and } \\
& d_{\mathrm{s}}=1.2 \mathrm{~b}^{0.8} \text { for bed material of medium gravel to coarser } \\
& \left(\mathrm{d}_{50}>8 \mathrm{~mm}\right) \text {. }
\end{aligned}
$$


Richardson and others $(1975,1988)$ :

$$
\frac{d_{s}}{y_{o}}=2.0 K_{1} K_{2}\left(\frac{b}{y_{o}}\right)^{0.65} F r^{0.43}
$$

where $K_{1}$ is 0.9 to 1.1 for pier shape, and

$K_{2}$ is 1.0 to 5.0 for angle of attack of flow.

Shen and others (1969):

$$
\begin{aligned}
& \frac{D_{e}}{b}=11.0\left(F_{p}\right)^{2} \text { for } F_{p}<.2 \\
& \frac{D_{e}}{b}=3.4\left(F_{p}\right)^{0.67} \text { for } F_{p}>.2
\end{aligned}
$$

where $\quad F_{p}$ is pier Froude number $=\frac{V}{\left(g b^{*}\right)^{0.5}}$.

In evaluating the applicability of the local scour equations, the following assumptions were made. For the equations using approach velocity as an independent variable, the maximum velocity that occurred in the vertical adjacent to the pier was obtained from the discharge measurements, which were made from the downstream side of the bridges. For equations using depth of flow as an independent variable, the average depth of the uncontracted section upstream of the bridge was used. In measuring the local scour, the reference surface used was the ambient bed elevation as explained by Landers and Mueller (1993).

\section{SCOUR ASSESSMENT AT COPPER RIVER HIGHWAY BRIDGES}

\section{Bridges 331,1187 , and 332}

Bridges 331, 1187, and 332 (fig. 2) are located at Flag Point, Mile 27 of the Copper River Highway, and are the first bridges that cross the Copper River east of Cordova. The present bridges were constructed during 1970-72 and are supported by concrete piers $5.5 \mathrm{ft}$ wide, $18 \mathrm{ft}$ long, and pointed at both ends (fig. 4-5). Bridges 331 and 332 are both $780 \mathrm{ft}$ long and each bridge is supported by three piers spaced $220 \mathrm{ft}$ apart. Bridge 1187 is $1,220 \mathrm{ft}$ long and is supported by five piers spaced $220 \mathrm{ft}$ apart. Spur dikes were constructed at the left upstream abutment of Bridge 331 and at both upstream abutments of Bridge 1187. The total design discharges for these three bridges was $440,000 \mathrm{ft}^{3} / \mathrm{s}$, approximately $120,000 \mathrm{ft}^{3} / \mathrm{s}$ each for Bridges 331 and 332 , and $200,000 \mathrm{ft}^{3} / \mathrm{s}$ for Bridge 1187 . 


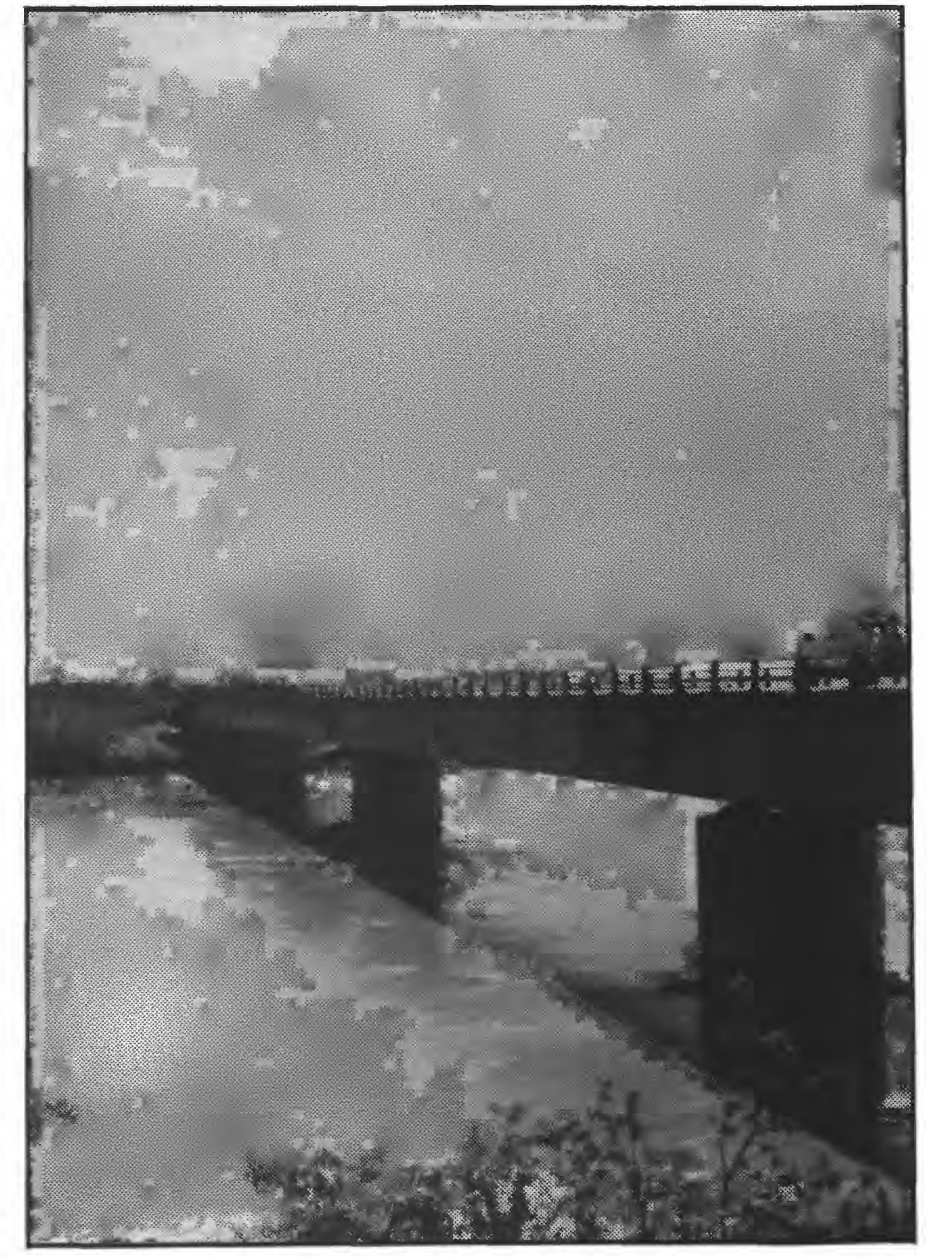

Figure 4. Bridge 331on the Copper River Highway in 1991.

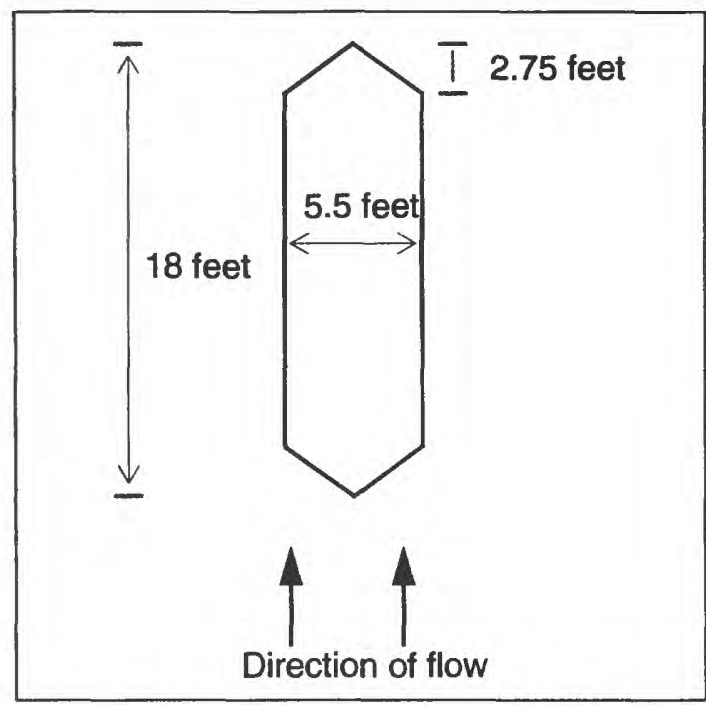

Figure 5. Plan view of piers constructed at Bridges 331, 1187, and 332 on the Copper River Highway. 
During the open-water periods of 1991 and 1992, discharges at Bridges 331, 1187, and 332 ranged from 16,600 to $56,600 \mathrm{ft}^{3} / \mathrm{s}$, from 0 to $38,600 \mathrm{ft}^{3} / \mathrm{s}$, and from 0 to $29,400 \mathrm{ft}^{3} / \mathrm{s}$ respectively (table 1). These discharges represent 24 to 54 percent, 0 to 21 percent, and 0 to 14 percent respectively, of the total flow past the Million Dollar Bridge and indicate that most of the discharge in this reach of the river flows through Bridge 331. Suspended-sediment concentrations ranged from 503 to $2,298 \mathrm{mg} / \mathrm{L}$ at Bridge 331, from 309 to $2,156 \mathrm{mg} / \mathrm{L}$ at Bridge 1187 , and from 560 to $2,095 \mathrm{mg} / \mathrm{L}$ at Bridge 332 (table 2). Most of the suspended sediment is finer than $0.062 \mathrm{~mm}$ : about half is classified as clay and about half is classified as silt (table 3). Bedload discharge ranged from 550 to 4,300 ton/d at Bridge 331, from 1,300 to 4,690 ton/d at Bridge 1187, and from 400 to 4,100 ton/d at Bridge 332 (table 4). Bedload transport at Bridge 332 is about the same or even greater than that at Bridges 331 or 1187, although the discharge at Bridge 332 was the lowest measured of the three sites. The median diameter of the bedload for Bridges 331, 1187, and 332 was generally less than $1 \mathrm{~mm}$. Most of the bed material at Bridges 331 and 1187 is composed of medium gravel (fig. 6A, B), while most of the bed material at Bridge 332 is composed of medium sand (fig. 6C).

On the basis of the design discharges for Bridges 331, 1187, and 332, and field notes from ADOT\&PF files, most of the discharge of the Copper River probably flowed through these bridges at the time of construction. This area is somewhat confined on the west side by mountains and on the east side by vegetated land. Analyses of aerial photography (fig. 7) indicated no major channel changes in this area between 1950 and 1991. Photography from different years shows the presence or absence of gravel bars. However, this is probably due to the different water stages when the photography was taken.

An approach cross section (uncontracted area) was surveyed at Bridge 331 in May 1992 (fig. 8A). Comparison with the downstream bridge cross sections (contracted area) indicates that distinct channels have formed on the left and right sides of the channel at the bridge. In 1968, the mean bed elevation of the channel was $13.6 \mathrm{ft}$ and on May 21, 1992 it was $4.5 \mathrm{ft}$, indicating that about $9.0 \mathrm{ft}$ of scour had occurred since 1968. On September 18, the mean bed elevation was $3.3 \mathrm{ft}$, indicating that some scour--both contraction and local--had occurred during the summer. During 1992, the maximum local scour that occurred was $6.5 \mathrm{ft}$ adjacent to pier 3.

At Bridge 1187, the approach cross section in the uncontracted area was fairly uniform and had a somewhat distinct channel on the right side (fig. 9A). This channel is more centered when comparing cross sections at the upstream and downstream sides of the bridge (fig. 9B, C). In 1968, the mean bed elevation was $11.8 \mathrm{ft}$ and in June 1992, the mean bed elevation was $9.6 \mathrm{ft}$, indicating that about $2 \mathrm{ft}$ of scour has occurred during this time. On September 18, the mean bed elevation was $8.2 \mathrm{ft}$, indicating that minor scour, both contraction and local, had occurred. The maximum local scour that occurred during 1992 was about $7.5 \mathrm{ft}$, measured near pier 4 . 


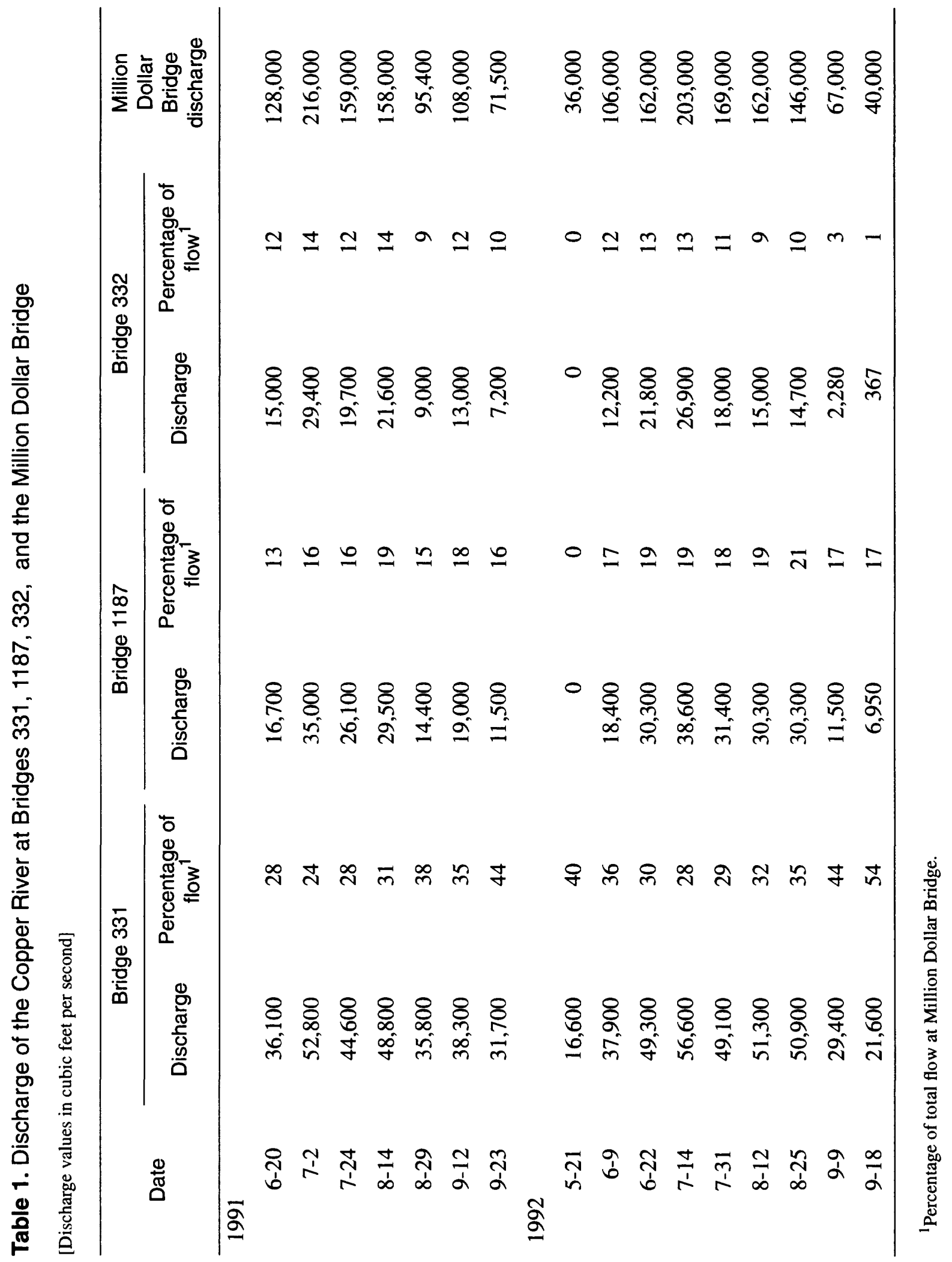


Table 2. Suspended-sediment data for the Copper River at Bridges 331, 1187, and 332 [ $\mathrm{ft}^{3} / \mathrm{s}$, cubic foot per second; $\mathrm{mg} / \mathrm{L}$, milligram per liter; ton/d, ton per day]

\begin{tabular}{|c|c|c|c|c|c|c|}
\hline \multirow[b]{2}{*}{ Bridge } & \multirow[b]{2}{*}{ Date } & \multirow[b]{2}{*}{ Time } & \multirow{2}{*}{$\begin{array}{c}\text { Water } \\
\text { discharge } \\
\left(\mathrm{ft}^{3} / \mathrm{s}\right)\end{array}$} & \multicolumn{3}{|c|}{ Suspended sediment } \\
\hline & & & & $\begin{array}{l}\text { Concen- } \\
\text { tration } \\
(\mathrm{mg} / \mathrm{L})\end{array}$ & $\begin{array}{l}\text { Discharge } \\
\text { (ton/d) }\end{array}$ & $\begin{array}{c}\text { Percent } \\
\text { finer than } \\
0.062 \mathrm{~mm}\end{array}$ \\
\hline \multirow[t]{12}{*}{331} & $6-20-91$ & 0920 & 36,100 & 805 & 78,500 & 84 \\
\hline & $7-02-91$ & 1500 & 52,800 & 1,690 & 241,000 & 90 \\
\hline & $7-24-91$ & 1600 & 44,600 & 1,290 & 155,000 & 88 \\
\hline & $8-14-91$ & 1530 & 48,800 & 2,010 & 265,000 & 83 \\
\hline & $8-29-91$ & 1540 & 35,800 & 503 & 48,600 & 99 \\
\hline & $9-12-91$ & 1845 & 38,300 & 963 & 99,600 & 78 \\
\hline & $9-23-91$ & 1200 & 31,700 & 664 & 56,800 & 98 \\
\hline & $6-11-92$ & 1630 & 37,900 & 783 & 80,100 & 80 \\
\hline & $6-23-92$ & 1730 & 49,300 & 891 & 119,000 & 77 \\
\hline & $8-12-92$ & 1510 & 51,300 & 2,300 & 319,000 & 91 \\
\hline & $9-9-92$ & 1415 & 29,400 & 748 & 59,400 & 82 \\
\hline & $9-22-92$ & 1300 & 21,600 & 1,220 & 71,200 & 90 \\
\hline \multirow[t]{12}{*}{1187} & $6-20-91$ & 0830 & 16,700 & 840 & 37,900 & 81 \\
\hline & $7-02-91$ & 1400 & 35,000 & 1,780 & 168,000 & 86 \\
\hline & $7-24-91$ & 1445 & 26,100 & 1,240 & 87,400 & 88 \\
\hline & 8-14-91 & 1500 & 29,500 & 2,020 & 161,000 & 84 \\
\hline & $8-29-91$ & 1445 & 14,400 & 772 & 30,000 & 93 \\
\hline & $9-12-91$ & 1830 & 19,000 & 913 & 46,800 & 82 \\
\hline & $9-23-91$ & 1215 & 11,500 & 564 & 17,500 & 98 \\
\hline & $6-11-92$ & 1600 & 18,400 & 843 & 41,900 & 78 \\
\hline & $6-23-92$ & 1700 & 30,300 & 788 & 64,500 & 82 \\
\hline & $8-12-92$ & 1430 & 30,300 & 2,160 & 177,000 & 94 \\
\hline & $9-9-92$ & 1345 & 11,500 & 592 & 18,400 & 90 \\
\hline & $9-22-92$ & 1310 & 7,950 & 309 & 6,630 & 94 \\
\hline \multirow[t]{11}{*}{332} & $6-19-91$ & 1700 & 15,000 & 750 & 30,400 & 85 \\
\hline & $7-02-91$ & 1300 & 29,400 & 1,530 & 121,000 & 92 \\
\hline & $7-24-91$ & 1300 & 19,700 & 1,170 & 62,200 & 90 \\
\hline & $8-14-91$ & 1410 & 21,600 & 1,880 & 110,000 & 85 \\
\hline & $8-29-91$ & 1345 & 9,000 & 875 & 21,300 & 94 \\
\hline & $9-12-91$ & 1800 & 13,000 & 861 & 30,200 & 85 \\
\hline & $9-23-91$ & 1240 & 7,200 & 664 & 12,900 & 98 \\
\hline & $6-11-92$ & 1530 & 12,200 & 852 & 28,100 & 74 \\
\hline & $6-23-92$ & 1515 & 21,800 & 798 & 47,000 & 83 \\
\hline & $8-12-92$ & 1330 & 15,000 & 2,100 & 85,000 & 96 \\
\hline & $9-9-92$ & 1245 & 2,280 & 560 & 3,450 & 89 \\
\hline
\end{tabular}




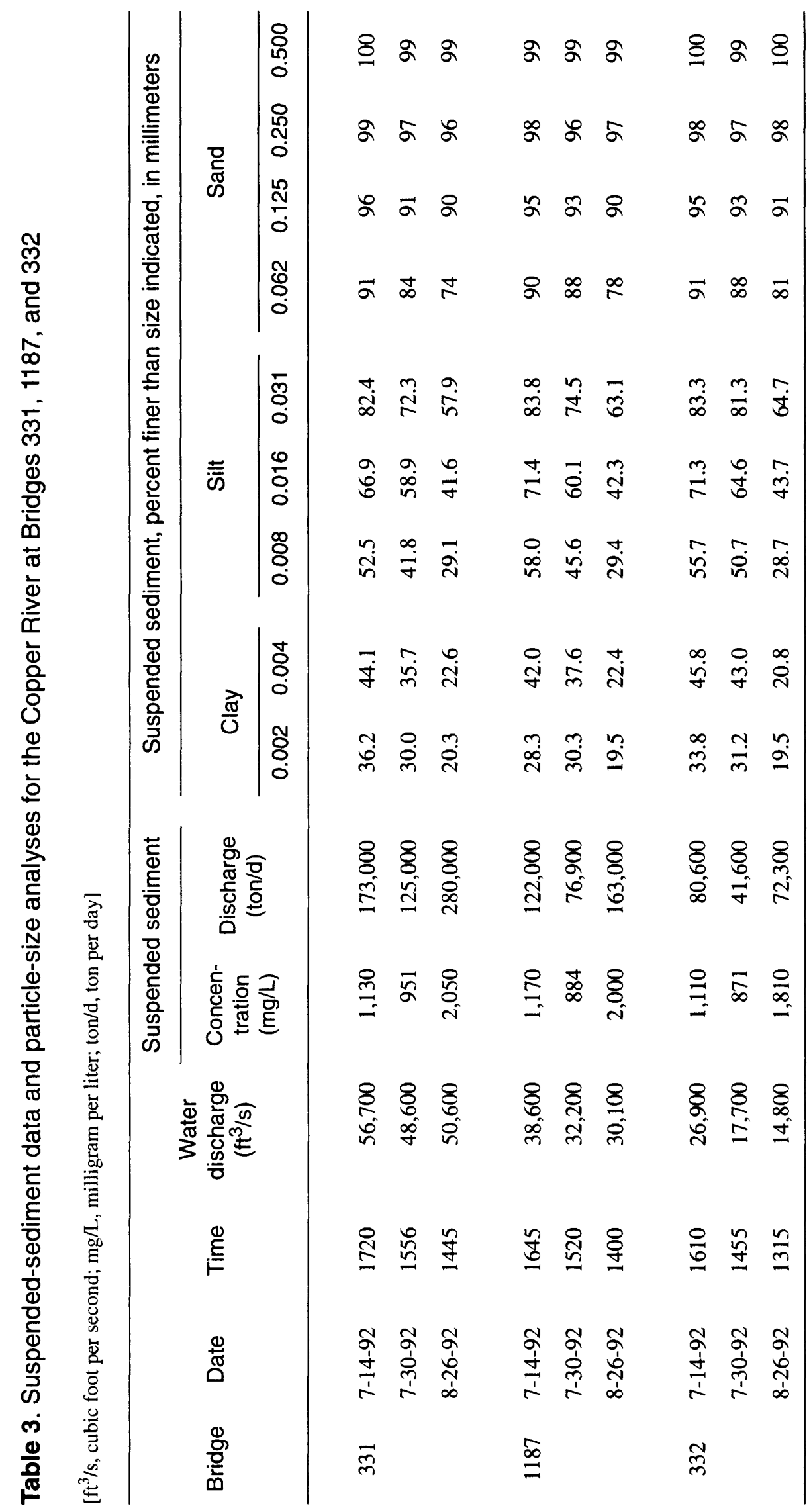


Table 4. Bedload data for the Copper River at Bridges 331, 1187, and 332 $\left[\mathrm{ft}^{3} / \mathrm{s}\right.$, cubic foot per second; $\mathrm{mm}$, millimeter; ton/d, ton per day]

\begin{tabular}{|c|c|c|c|c|c|}
\hline Bridge & Date & Time & $\begin{array}{c}\text { Water } \\
\text { discharge } \\
\left(\mathrm{ft}^{3} / \mathrm{s}\right)\end{array}$ & $\begin{array}{c}\text { Median } \\
\text { diameter } \\
\left(d_{50}\right)(\mathrm{mm})\end{array}$ & $\begin{array}{c}\text { Bedload } \\
\text { discharge } \\
\text { (ton } / d)\end{array}$ \\
\hline \multirow[t]{11}{*}{331} & $6-20-91$ & 0920 & 36,100 & 1.9 & 4,300 \\
\hline & $7-02-91$ & 1500 & 52,800 & 1.5 & 1,300 \\
\hline & $7-24-91$ & 1600 & 44,600 & 0.4 & 750 \\
\hline & $8-14-91$ & 1530 & 48,800 & 2.3 & 1,850 \\
\hline & $8-29-91$ & 1540 & 35,800 & 1.0 & 550 \\
\hline & $6-11-92$ & 1500 & 37,900 & 1.4 & 2,600 \\
\hline & $6-24-92$ & 1000 & 48,600 & 3.0 & 3,450 \\
\hline & $7-14-92$ & 1300 & 56,600 & 1.3 & 3,300 \\
\hline & $7-30-92$ & 1240 & 48,600 & 1.2 & 1,750 \\
\hline & $8-13-92$ & 1600 & 50,600 & .7 & 730 \\
\hline & $8-26-92$ & 1600 & 50,600 & 1.0 & 2,170 \\
\hline \multirow[t]{10}{*}{1187} & $6-20-91$ & 0830 & 16,700 & .6 & 1,700 \\
\hline & $7-02-91$ & 1400 & 35,000 & .6 & 2,200 \\
\hline & $7-24-91$ & 1445 & 26,100 & 1.8 & 3,500 \\
\hline & $8-14-91$ & 1500 & 29,500 & .9 & 3,600 \\
\hline & $8-29-91$ & 1445 & 14,400 & .4 & 1,300 \\
\hline & $6-11-92$ & 1400 & 18,400 & .5 & 1,540 \\
\hline & $6-24-92$ & 1100 & 30,300 & 1.0 & 1,450 \\
\hline & 7-14-92 & 1400 & 38,600 & .6 & 4,010 \\
\hline & $7-30-92$ & 1030 & 32,200 & .8 & 3,880 \\
\hline & $8-26-92$ & 1430 & 30,100 & 1.4 & 4,690 \\
\hline \multirow[t]{10}{*}{332} & $6-19-91$ & 1700 & 15,000 & .6 & 2,000 \\
\hline & $7-02-91$ & 1300 & 29,400 & .9 & 2,000 \\
\hline & 7-24-91 & 1300 & 19,700 & .6 & 2,500 \\
\hline & 8-14-91 & 1410 & 21,600 & .6 & 4,100 \\
\hline & $8-29-91$ & 1345 & 21,300 & .7 & 400 \\
\hline & $6-11-92$ & 1100 & 12,200 & .9 & 3,800 \\
\hline & $6-23-92$ & 0900 & 21,800 & .8 & 2,350 \\
\hline & $7-14-92$ & 1200 & 26,900 & .7 & 3,340 \\
\hline & $7-30-92$ & 0840 & 17,700 & .5 & 1,380 \\
\hline & $8-26-92$ & 1300 & 14,800 & .5 & 1,280 \\
\hline
\end{tabular}



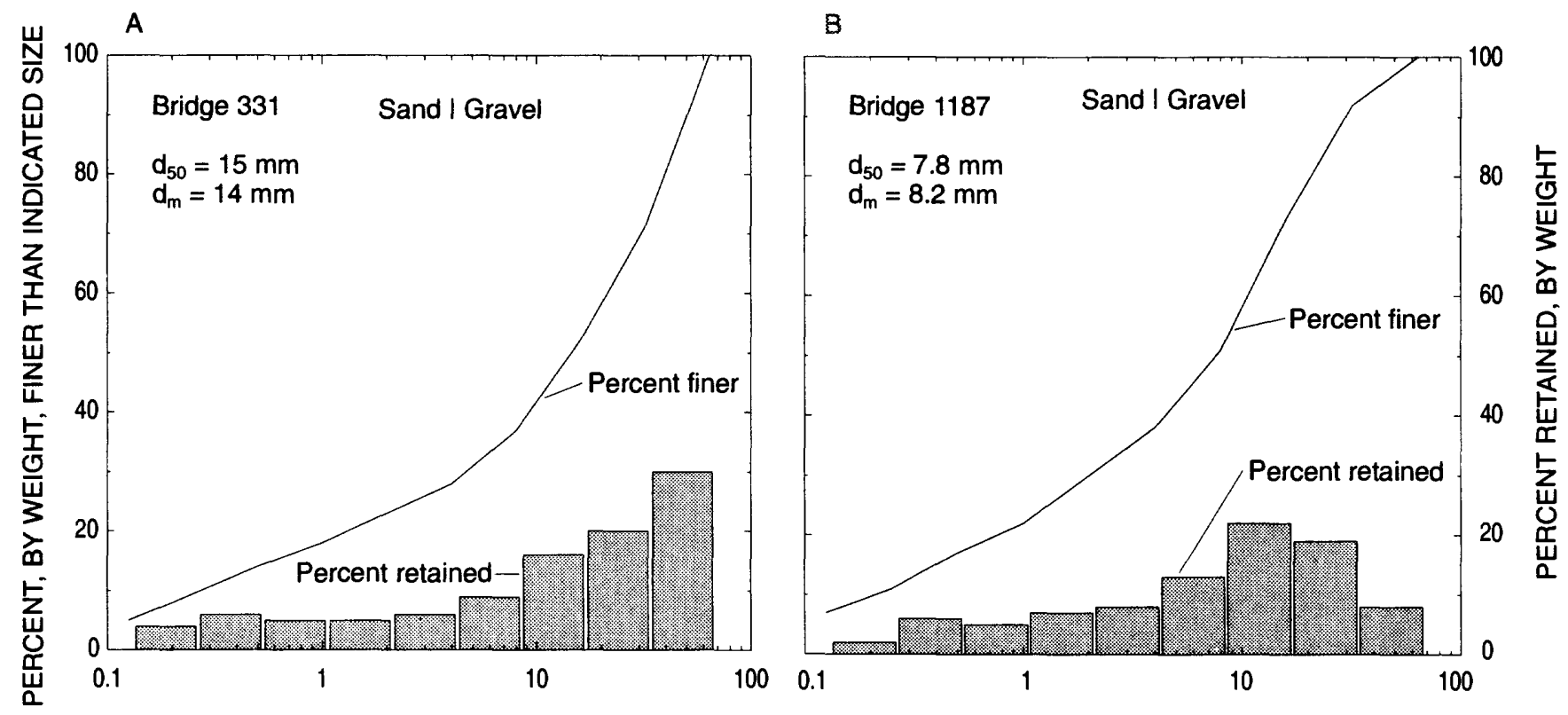

PARTICLE SIZE, IN MILLIMETERS

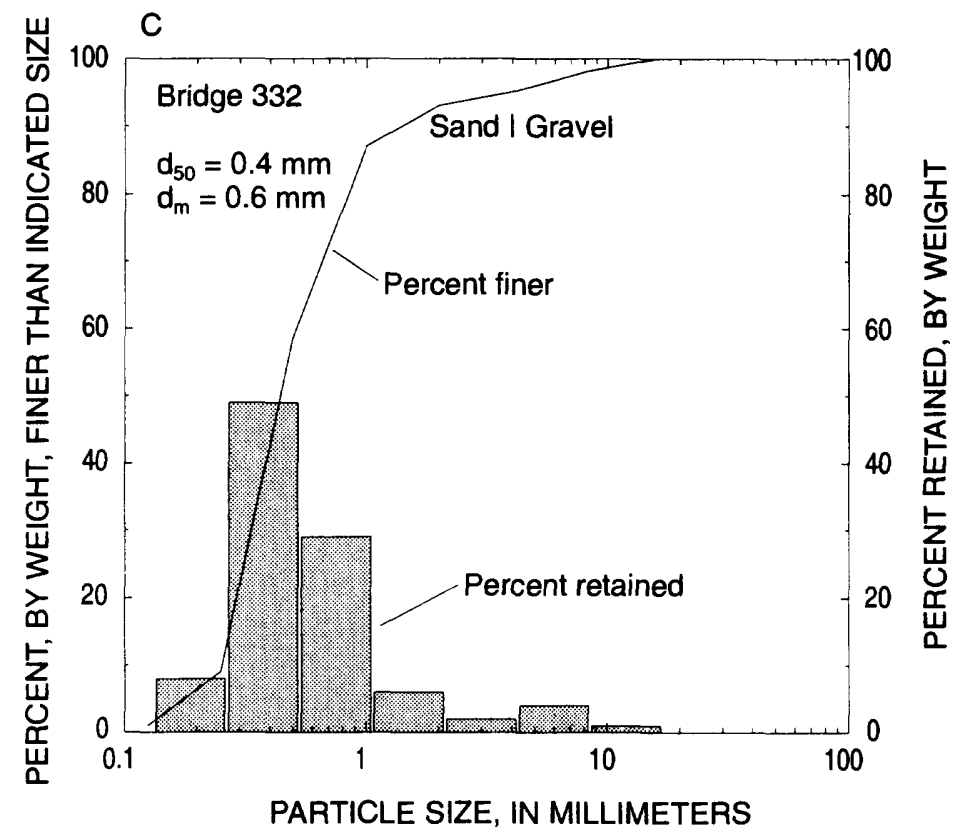

Figure 6. Particle-size distribution, median diameter $\left(d_{50}\right)$, and mean diameter $\left(d_{m}\right)$ of bed material, Copper River at Bridges 331, 1187, and 332. 

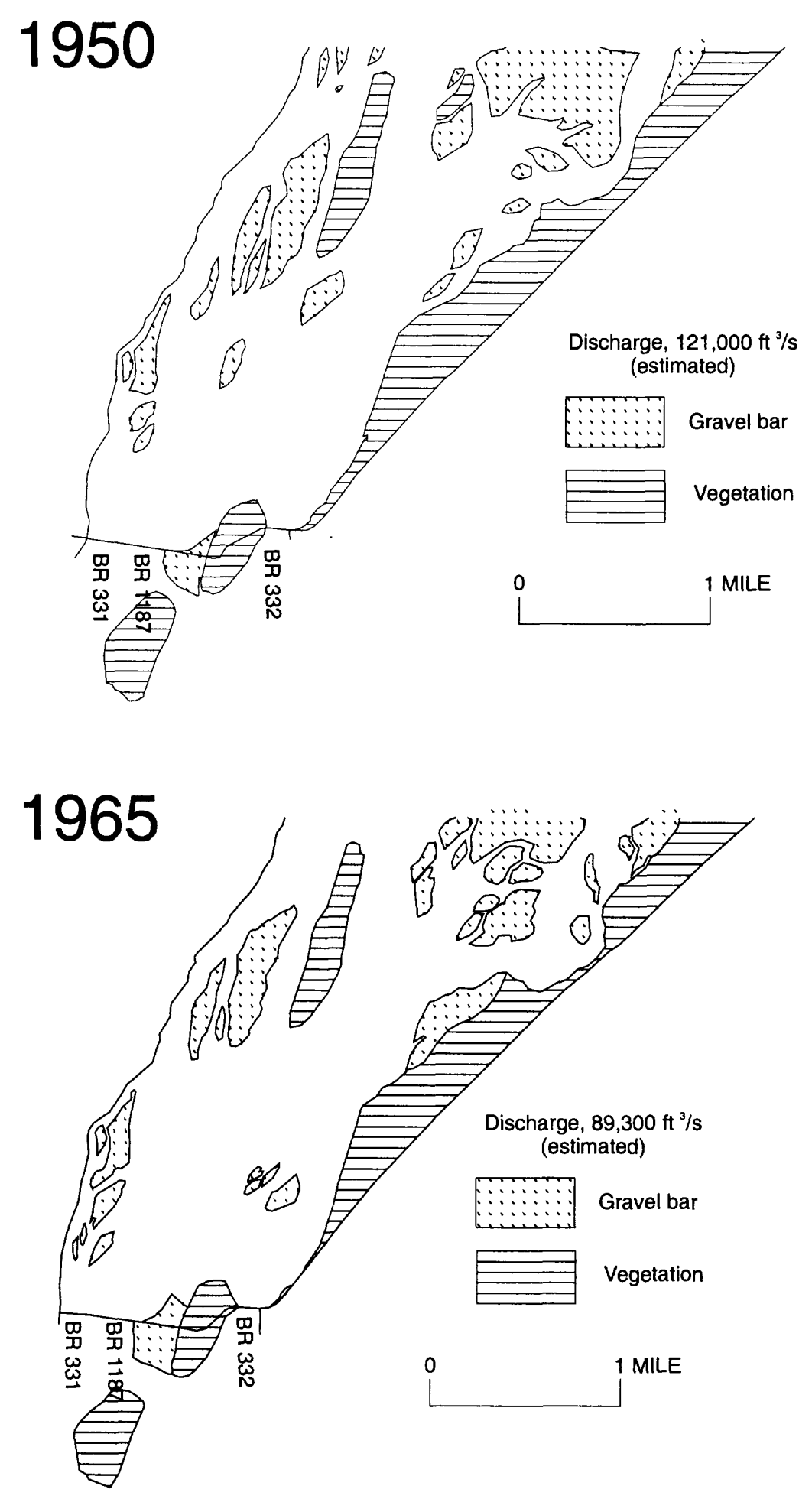

Figure 7. Maps of the Copper River at Flag Point, based on aerial photographs taken from 1950-91. 

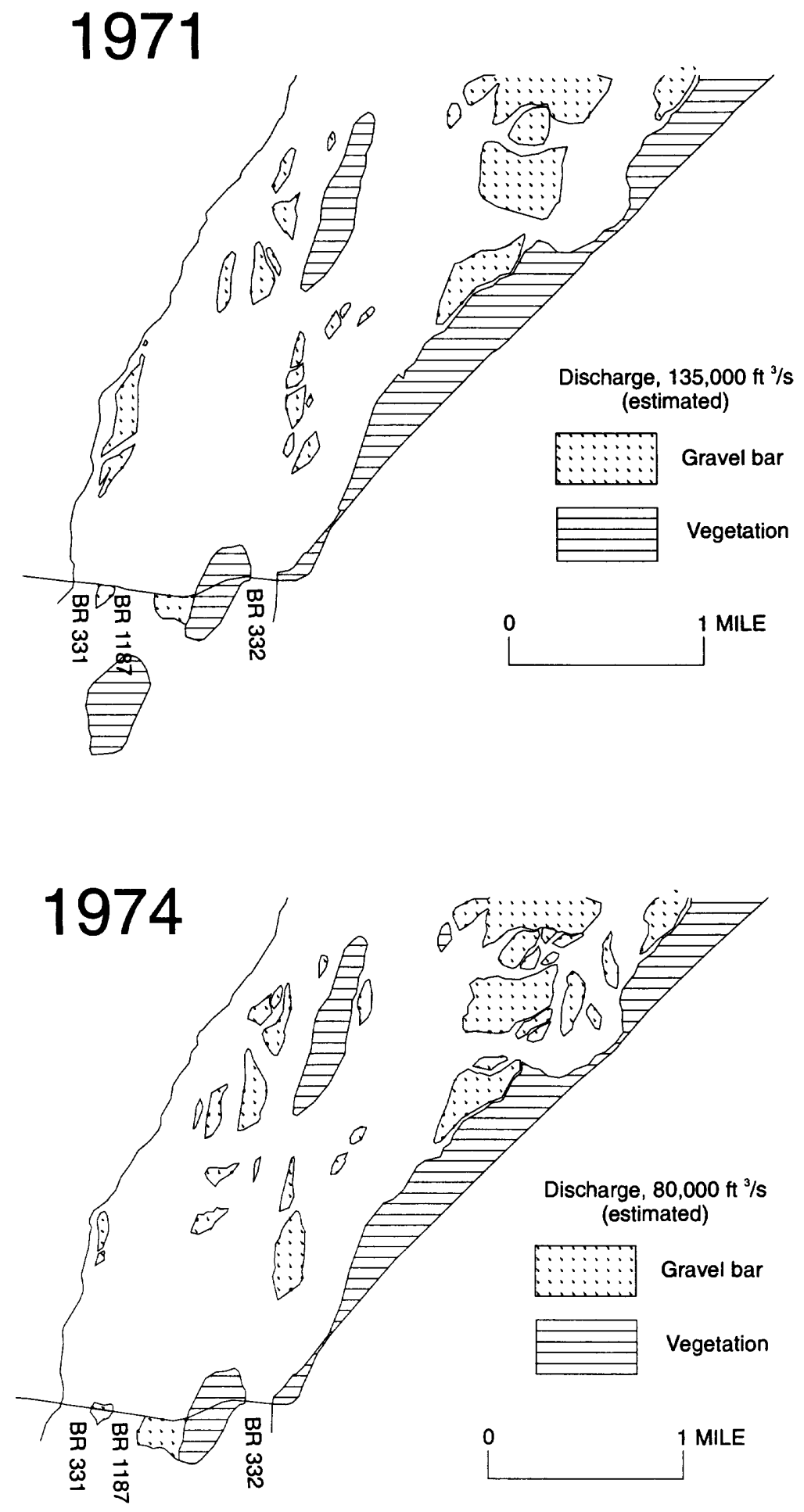

Figure 7.Continued. 

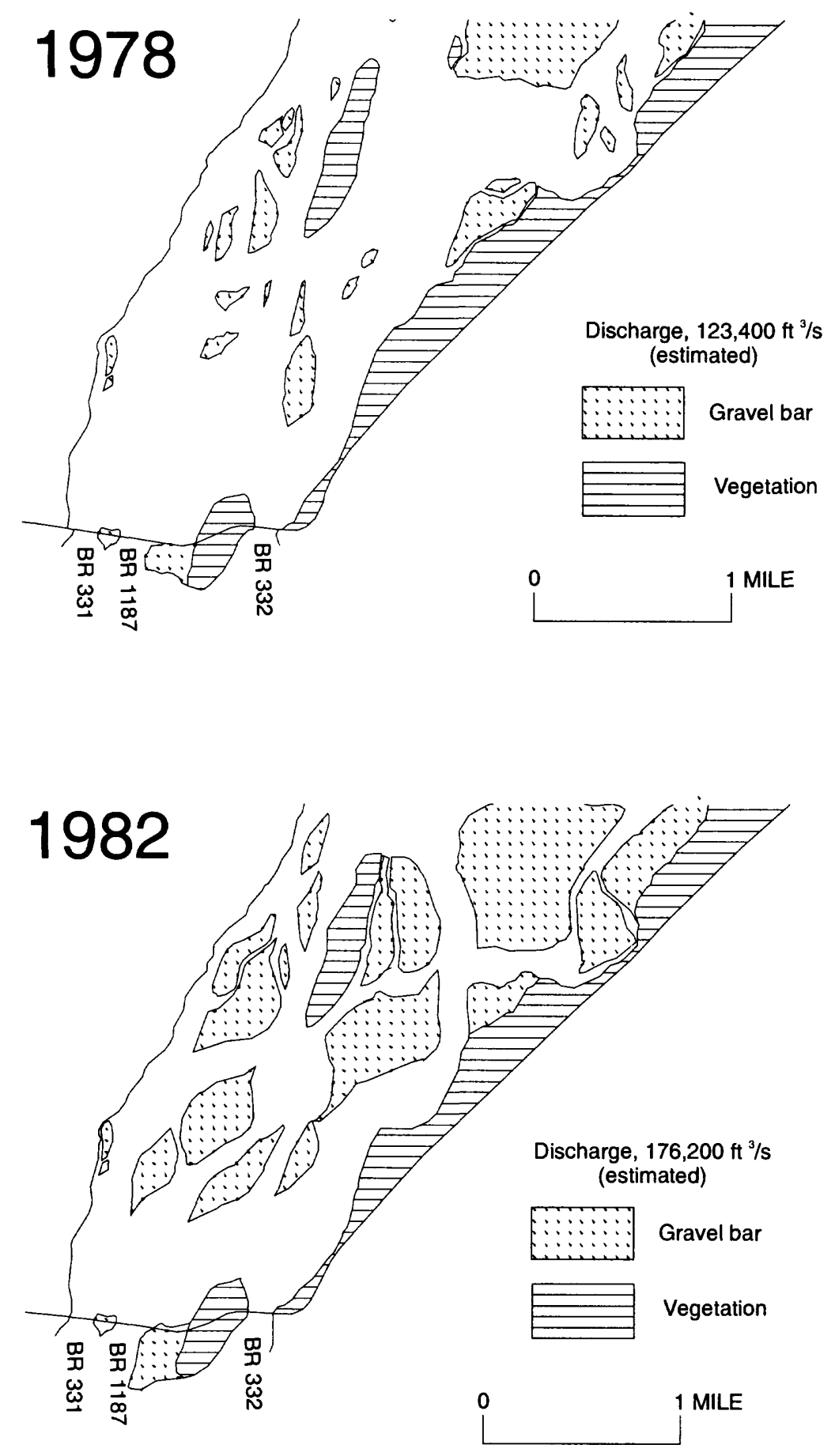

Figure 7.Continued. 

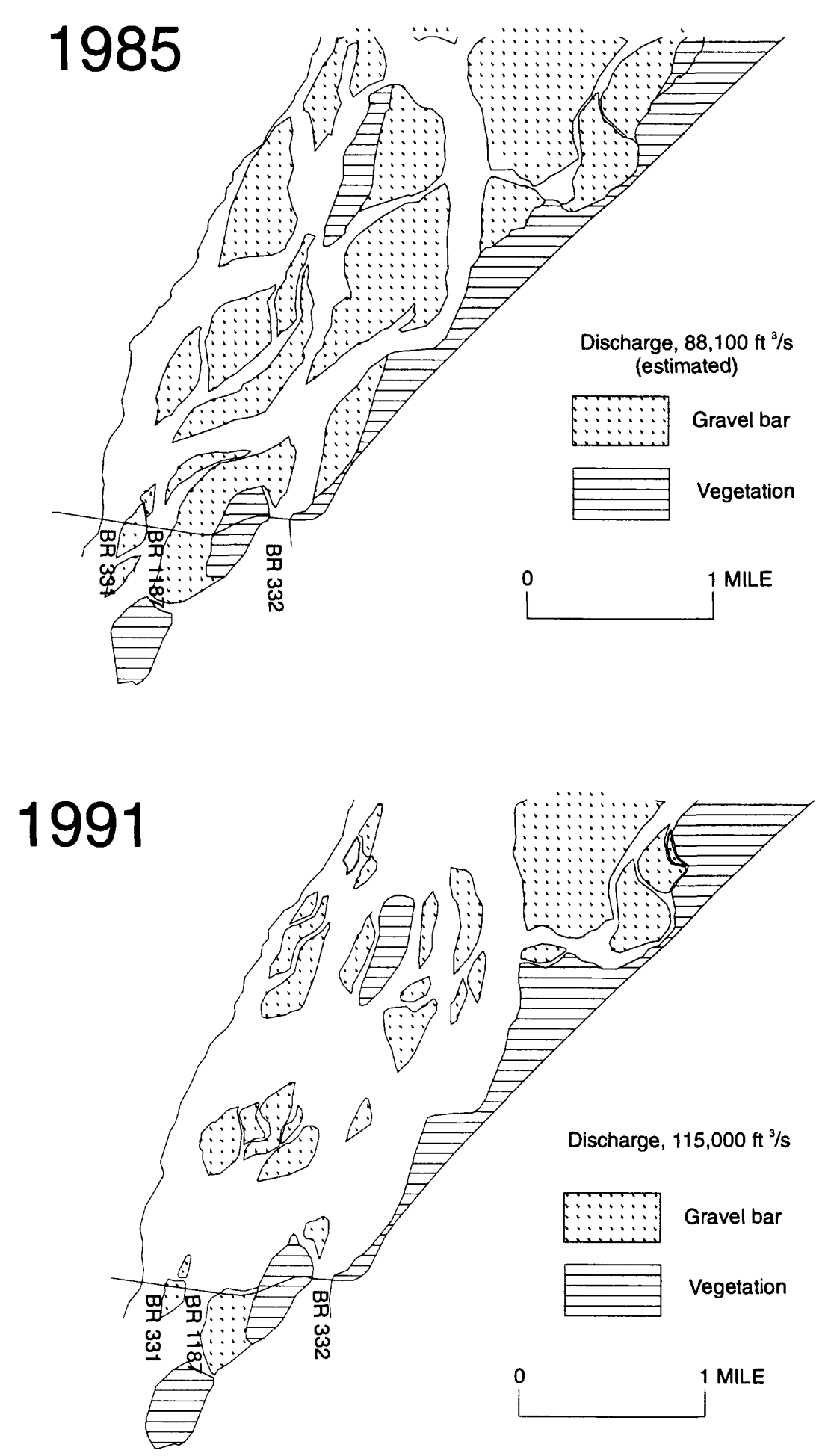

Figure 7.Continued. 

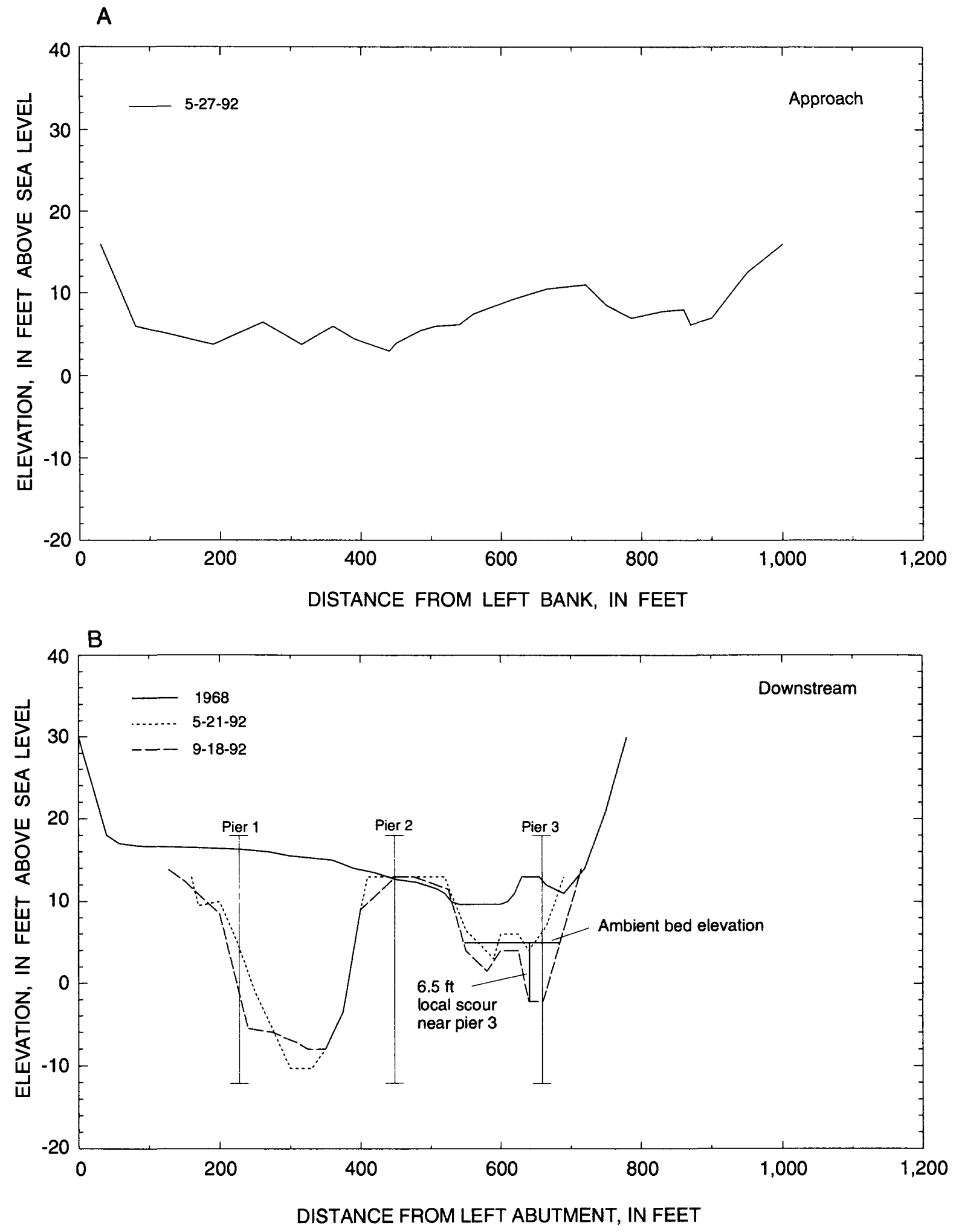

Figure 8. Approach and downstream cross sections of the Copper River at Bridge 331. 


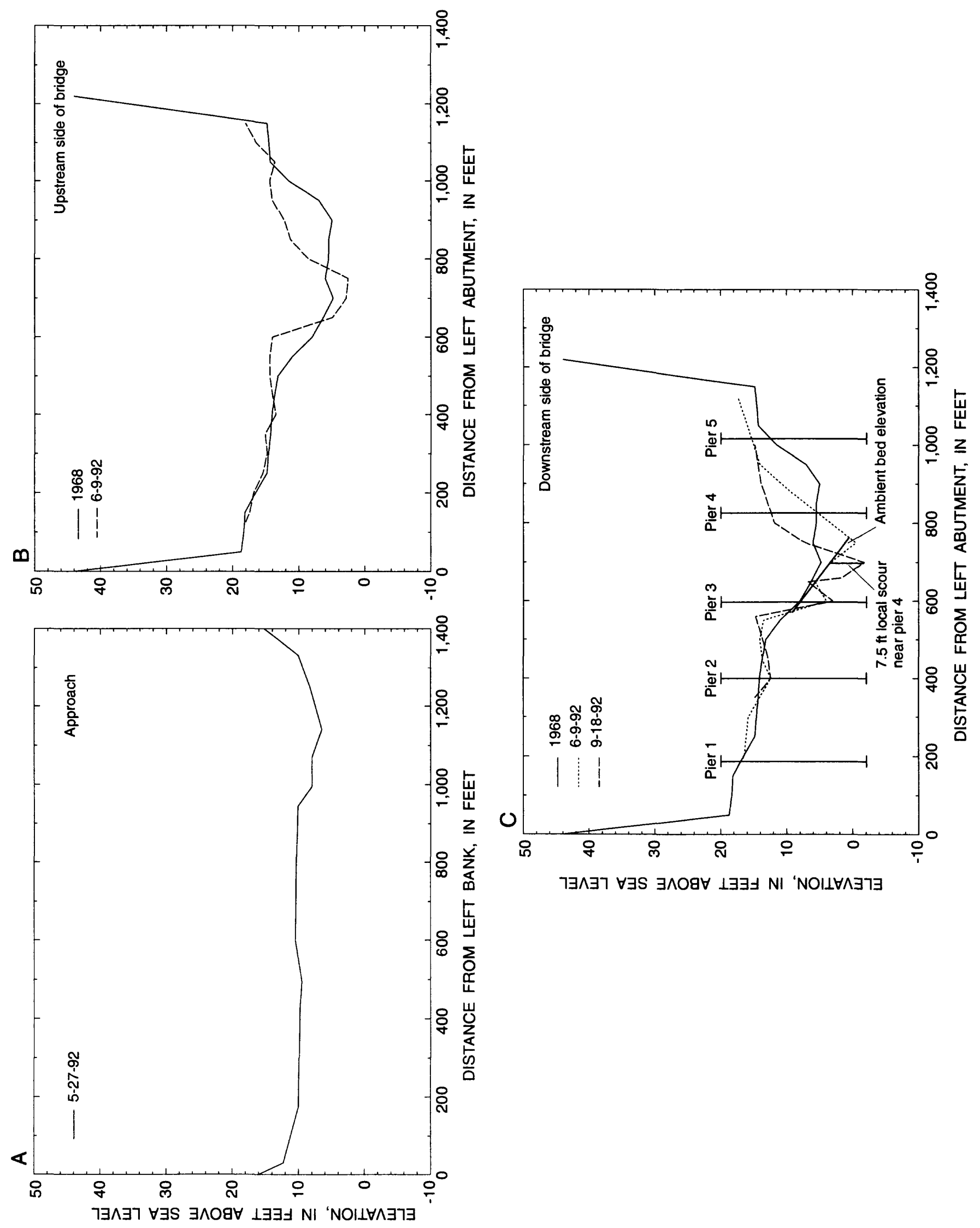


Comparison of cross sections at both the upstream (fig. 10A) and downstream (fig. 10B) sides of Bridge 332 indicates that the channel filled in at this bridge between 1968 and June 1992. In 1968, the mean bed elevation of the channel was $8.5 \mathrm{ft}$ and in June 1992, the mean bed elevation was $10.4 \mathrm{ft}$, indicating almost $2 \mathrm{ft}$ of filling. However, during 1992, the left part of the channel scoured out and the right part of the channel filled in. The net effect of the scour and fill lowered the mean bed elevation from $10.4 \mathrm{ft}$ in June to $5.0 \mathrm{ft}$ in September. A relatively large quantity of bedload was transported past this site in 1992 indicating that the channel may have been somewhat unstable. Although the maximum scour measured near pier 1 was $13.0 \mathrm{ft}$, it is probably not local scour.

The contraction scour equations were tested for Bridge 331 and Bridge 1187 because approach cross sections in uncontracted areas and contracted areas for these two sites had been obtained in May 1992. The equations were solved for the mean depth of flow, $\mathrm{d}_{2}$, and then compared with the measured mean depth of flow, $d_{2}$. For Bridge 331 , all three equations overpredicted the mean depth of flow from 3 to $5 \mathrm{ft}$ (table 5). However, the results for Bridge 1187 were quite close to the measured mean depth of flow, $7.8 \mathrm{ft}$. All predicted values were within $1.0 \mathrm{ft}$.

Table 5. Measured and predicted mean depth of flow at Bridges 331 and 1187 on the Copper River Highway, May 1992

[Values in feet]

\begin{tabular}{cccccccc}
\hline \multirow{2}{*}{ Bridge } & \multicolumn{2}{c}{ Measured mean depth of flow } & & \multicolumn{2}{c}{ Predicted mean depth of flow, $d_{2}$, from equation } \\
\cline { 2 - 3 } & $d_{1}$ & $d_{2}$ & & Straub & Laursen & Komura \\
\hline 331 & 9.4 & 10.8 & & 13.8 & 13.4 & 15.8 \\
1187 & 6.7 & 7.8 & & 8.2 & 8.1 & 8.8 \\
\hline
\end{tabular}

The results from the comparison of measured and calculated local scour were varied (table 6). For Bridge 331, those equations using velocity directly as a variable have the highest predicted scour values, while those using Froude number or not using velocity have values relatively similar to the measured scour. This may indicate that the velocity measured at the downstream side of the bridge and used for these equations, $8.0 \mathrm{ft} / \mathrm{s}$, may not represent the velocity upstream from the pier. The equations that use bed material as a variable also gave predicted values higher than the measured value. The Richardson equation provided the closest value to measured scour.

For Bridge 1187, the equations using velocity as input gave more reasonable results, indicating that the value of velocity used in the equations, $4.4 \mathrm{ft} / \mathrm{s}$, was a reasonable estimate. Of the 10 equations tested, half gave values less than the measured local scour. 

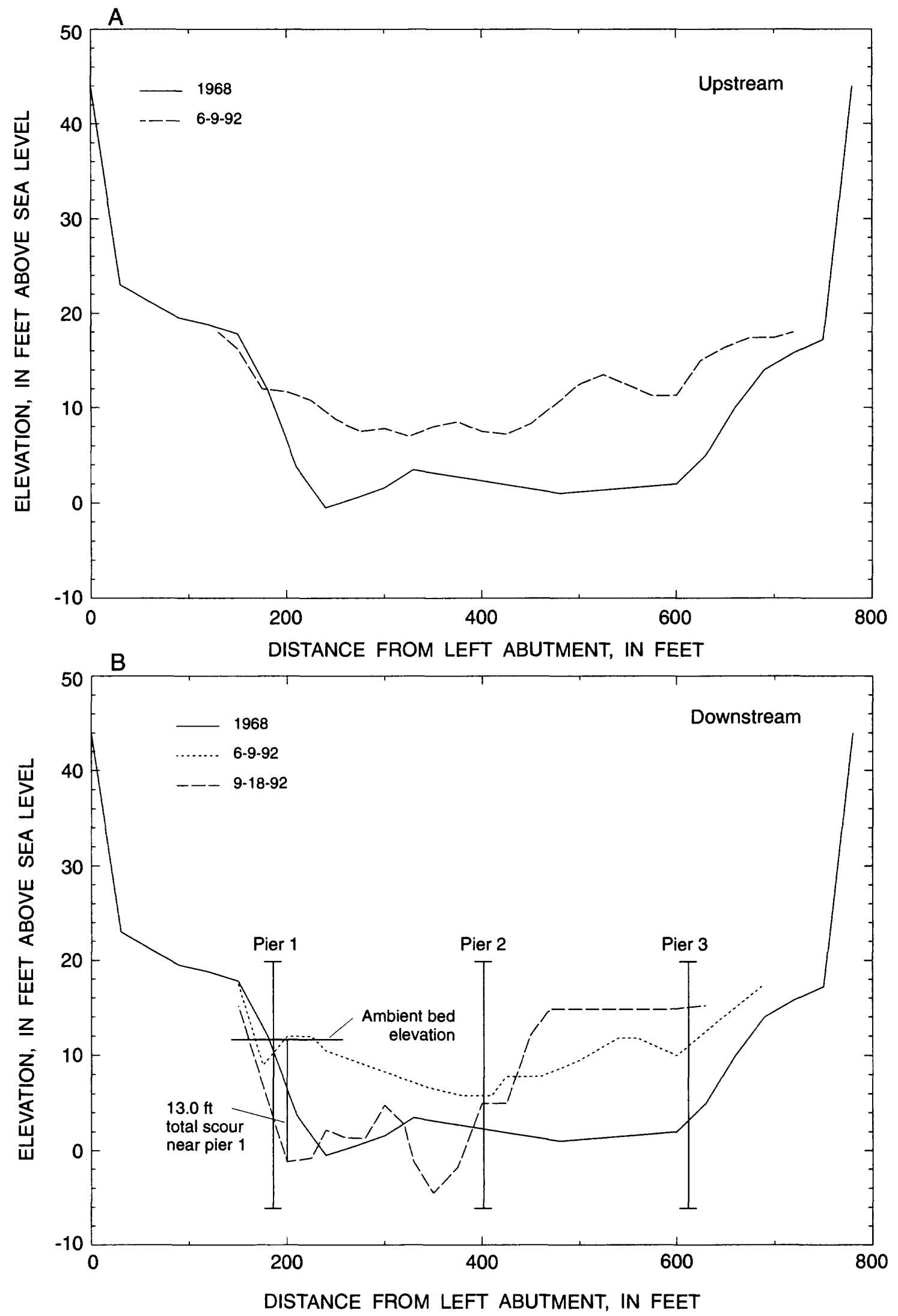

Figure 10. Upstream and downstream cross sections of the Copper River at Bridge 332. 
Table 6. Measured and predicted local scour at Bridges 331 and 1187 on the Copper River Highway

\begin{tabular}{|c|c|c|}
\hline Equation & Bridge 331 & Bridge 1187 \\
\hline & \multicolumn{2}{|c|}{$\begin{array}{l}\text { Maximum velocity }{ }^{1} \\
\text { (feet per second) }\end{array}$} \\
\hline \multirow[t]{2}{*}{---} & 8.0 & 4.4 \\
\hline & \multicolumn{2}{|c|}{ Measured scour (feet) } \\
\hline \multirow[t]{2}{*}{--} & 6.5 & 7.5 \\
\hline & \multicolumn{2}{|c|}{ Predicted scour (feet) } \\
\hline Bata $^{2,3}$ & 17.9 & 5.4 \\
\hline Breusers & 7.7 & 7.7 \\
\hline Carstens ${ }^{2,3}$ & 10.4 & 4.1 \\
\hline Chitale $^{2}$ & 12.7 & 7.3 \\
\hline Froehlich ${ }^{2,3}$ & 7.4 & 7.1 \\
\hline Laursen & 9.7 & 8.9 \\
\hline Neil & 9.7 & 8.8 \\
\hline Norman $^{3}$ & 7.8 & 7.8 \\
\hline Richardson $^{2}$ & 6.3 & 5.5 \\
\hline Shen $^{2}$ & 13.2 & 8.9 \\
\hline
\end{tabular}

${ }^{1}$ Maximum velocity in vertical adjacent to pier, downstream side of bridge.

${ }^{2}$ Equation uses velocity as a variable.

${ }^{3}$ Equation uses bed material as a variable.

\section{Bridges 333 and 334}

Bridge 333 and 334 are located at Miles 33.3 and 34.3 of the Copper River Highway (fig. 2). The bridges were constructed during 1976-78. Bridge 333 is $240 \mathrm{ft}$ long and is supported by two sets of concrete-filled steel cylindrical piers, spaced $80 \mathrm{ft}$ apart (fig. 11). Bridge 334 is 1,200 ft long and is supported by 14 sets of concrete-filled steel cylindrical pipes, spaced $80 \mathrm{ft}$ apart. Each pipe is circular and has a diameter of $30 \mathrm{in}$. The two pipes in a set are connected by a concrete cap (fig. 12). Spur dikes were constructed at the upstream right abutment at Bridge 333 and at both upstream abutments at Bridge 334. The design discharge of Bridge 333 is $10,500 \mathrm{ft}^{3} / \mathrm{s}$ and the design discharge of Bridge 334 is $82,000 \mathrm{ft}^{3} / \mathrm{s}$. 


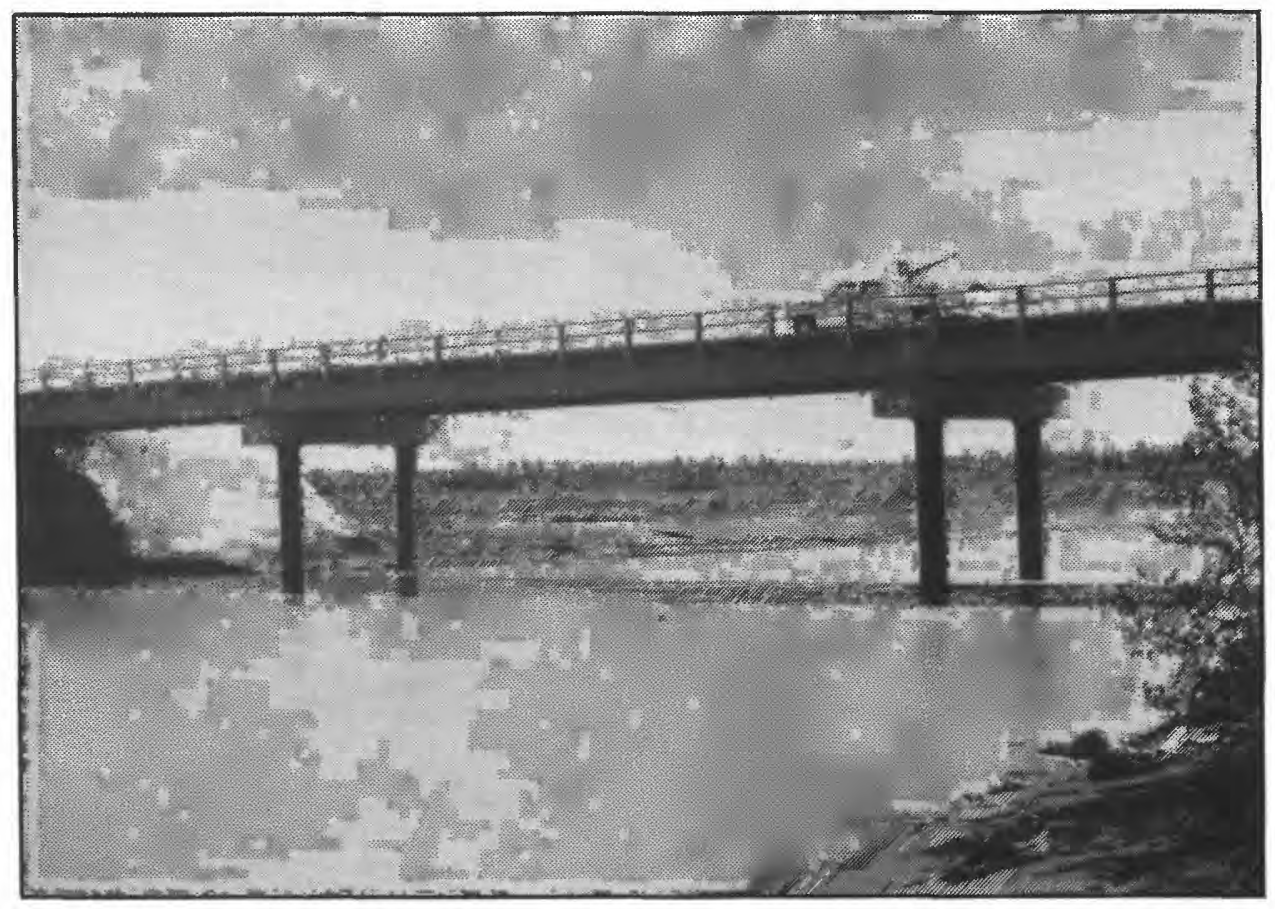

Figure 11. Bridge 333 on the Copper River Highway in 1991.

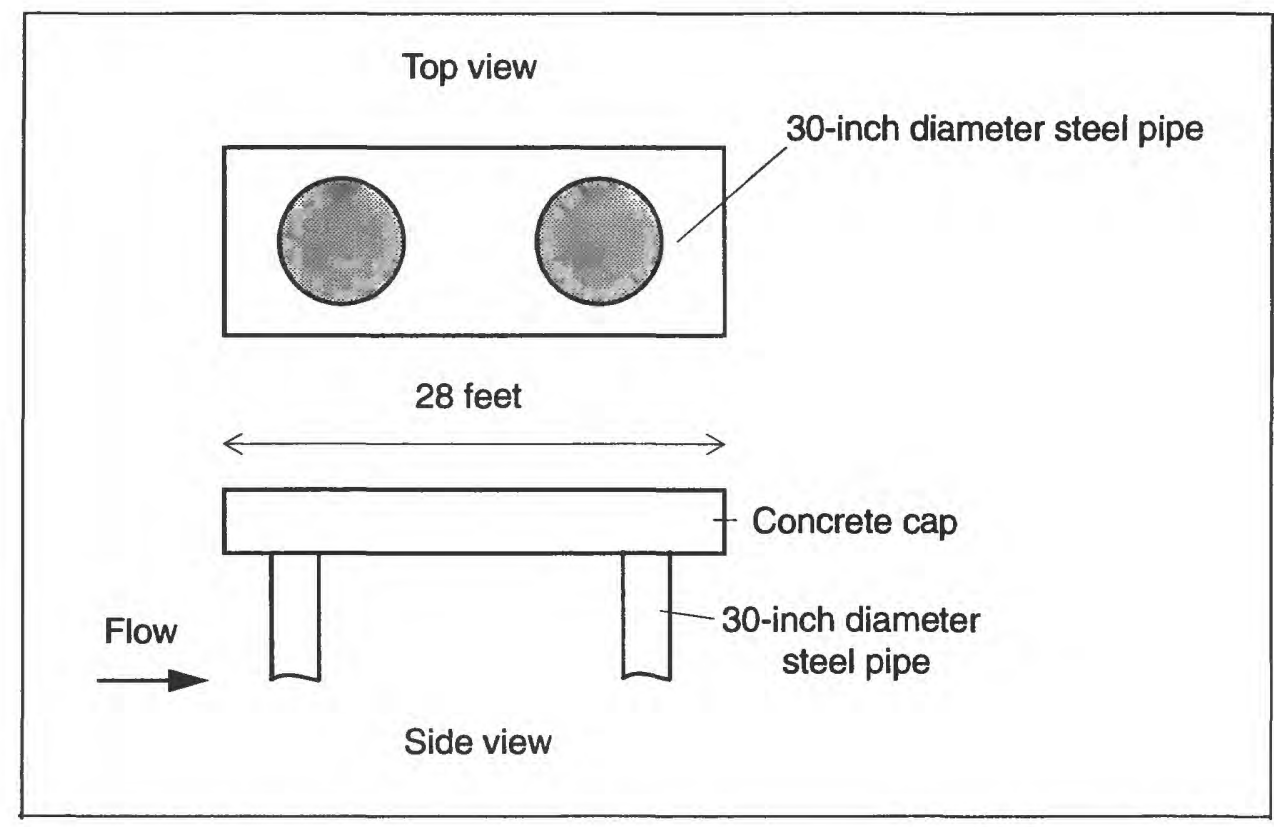

Figure 12. Top and side views of piers at Bridges 333 and 334 on the Copper River Highway. 
During the open-water periods of 1991 and 1992, measured discharges at Bridge 333 ranged from 100 to $8,700 \mathrm{ft}^{3} / \mathrm{s}$ and at Bridge 334 measured discharges ranged from 0 to $13,100 \mathrm{ft}^{3} / \mathrm{s}$ (table 7). These discharges represent less than 6 percent of the total discharge past the Million Dollar Bridge. The discharges measured at Bridge 334 were significantly lower than the design discharge for this bridge. Suspended-sediment concentrations at Bridge 333 ranged from 485 to $1,780 \mathrm{mg} / \mathrm{L}$ and at Bridge 334 ranged from 252 to $1,990 \mathrm{mg} / \mathrm{L}$ (table 8 ). Most of the sediment is finer than $0.062 \mathrm{~mm}$. No bedload or bed material samples were collected at these sites because the discharges at these sites were considered insignificant.

Table 7. Discharge of the Copper River at Bridges 333,334 , and the Million Dollar Bridge [Data values in cubic feet per second]

\begin{tabular}{|c|c|c|c|c|c|}
\hline \multirow[b]{2}{*}{ Date } & \multicolumn{2}{|c|}{ Bridge 333} & \multicolumn{2}{|c|}{ Bridge 334} & \multirow{2}{*}{$\begin{array}{c}\text { Million } \\
\text { Dollar Bridge } \\
\text { discharge }\end{array}$} \\
\hline & Discharge & $\begin{array}{l}\text { Percentage } \\
\text { of flow }{ }^{1}\end{array}$ & Discharge & $\begin{array}{l}\text { Percentage } \\
\text { of flow }\end{array}$ & \\
\hline \multicolumn{6}{|l|}{1991} \\
\hline $6-19$ & 2,600 & 2 & 1,800 & 1 & 128,000 \\
\hline $7-1$ & 5,800 & 3 & 12,000 & 6 & 216,000 \\
\hline $7-24$ & 4,700 & 3 & 5,000 & 3 & 159,000 \\
\hline $8-13$ & 5,000 & 3 & 6,000 & 4 & 158,000 \\
\hline $8-28$ & 2,200 & 2 & 600 & $<1$ & 95,400 \\
\hline $9-12$ & 2,500 & 2 & 1,000 & 1 & 108,000 \\
\hline $9-23$ & 800 & $<1$ & 400 & $<1$ & 71,500 \\
\hline \multicolumn{6}{|l|}{1992} \\
\hline $6-8$ & 2,200 & 2 & 620 & $<1$ & 106,000 \\
\hline $6-22$ & 5,100 & 3 & 5,600 & 3 & 162,000 \\
\hline $7-14$ & 8,700 & 4 & 13,100 & 6 & 203,000 \\
\hline $7-31$ & 4,900 & 3 & 5,500 & 3 & 169,000 \\
\hline $8-11$ & 5,200 & 3 & 8,500 & 5 & 162,000 \\
\hline $8-24$ & 2,500 & 2 & 3,900 & 3 & 146,000 \\
\hline $9-8$ & 710 & 1 & 246 & 1 & 67,000 \\
\hline $9-18$ & 100 & $<1$ & 0 & & 40,000 \\
\hline
\end{tabular}

${ }^{1}$ Percentage of total flow at Million Dollar Bridge

Because of the different discharges present when the aerial photography (fig. 13) was taken, it is difficult to determine if or when significant channel changes occurred at these two bridges. For example, although more gravel bars seem be present in 1965, 1974, and 1985, these years also correspond to relatively lower discharges of the Copper River (less than $100,000 \mathrm{ft}^{3} / \mathrm{s}$ ). However, a comparison of the 1950 and 1991 photography, which was taken at similar discharges, shows some areas of gravel deposits near these two bridges.

Comparison of cross sections at Bridge 333 (fig. 14) indicates that a distinct channel has formed on the right side since 1968. In 1968, the mean bed elevation was $40.7 \mathrm{ft}$ and in June 1992, it was $33.1 \mathrm{ft}$, indicating almost $8.0 \mathrm{ft}$ of scour during this time. Some scour occurred in 1992, but the channel appears to be relatively stable. At Bridge 334, comparison of the 1968 cross sections with the 1992 cross sections (fig. 15) indicates that a distinct channel present in 1968 has filled and a new channel has formed near the right abutment. Mean bed elevations for 1968 and 1992 indicate about $2.0 \mathrm{ft}$ of filling: $42.1 \mathrm{ft}$ in 1968 and $43.7 \mathrm{ft}$ in 1992. During 1992, the channel remained stable. 
Table 8. Suspended-sediment data for the Copper River at Bridges 333 and 334 [ $\mathrm{ft}^{3} / \mathrm{s}$, cubic foot per second; $\mathrm{mg} / \mathrm{L}$, milligram per liter; ton/d, ton per day]

\begin{tabular}{|c|c|c|c|c|c|c|}
\hline \multirow[b]{2}{*}{ Bridge } & \multirow[b]{2}{*}{ Date } & \multirow[b]{2}{*}{ Time } & \multirow{2}{*}{$\begin{array}{c}\text { Water } \\
\text { discharge } \\
\left(\mathrm{ft}^{3} / \mathrm{s}\right)\end{array}$} & \multicolumn{3}{|c|}{ Suspended sediment } \\
\hline & & & & $\begin{array}{l}\text { Concen- } \\
\text { tration } \\
(\mathrm{mg} / \mathrm{L})\end{array}$ & $\begin{array}{l}\text { Discharge } \\
\text { (ton/d) }\end{array}$ & $\begin{array}{l}\text { Percent } \\
\text { finer than } \\
0.062 \mathrm{~mm}\end{array}$ \\
\hline \multirow[t]{12}{*}{333} & $7-02-91$ & 1725 & 5,800 & 1,310 & 20,500 & 99 \\
\hline & $7-25-91$ & 1220 & 4,700 & 1,060 & 13,500 & 97 \\
\hline & $8-15-91$ & 1350 & 5,000 & 1,410 & 19,000 & -- \\
\hline & $8-28-91$ & 1310 & 2,200 & 781 & 4,640 & 96 \\
\hline & $9-25-91$ & 1145 & 800 & 546 & 1,180 & 93 \\
\hline & $6-10-92$ & 1445 & 2,100 & 532 & 3,020 & 90 \\
\hline & $6-23-92$ & 1515 & 4,900 & 583 & 7,710 & 98 \\
\hline & $7-13-92$ & 1730 & 8,700 & 1,220 & 28,700 & 96 \\
\hline & $7-31-92$ & 1430 & 4,900 & 781 & 10,300 & 95 \\
\hline & $8-13-92$ & 1325 & 5,200 & 1,780 & 25,000 & 97 \\
\hline & $8-27-92$ & 1530 & 2,500 & 1,080 & 7,290 & 95 \\
\hline & $9-9-92$ & 1505 & 800 & 485 & 1,050 & 99 \\
\hline \multirow[t]{12}{*}{334} & $7-02-91$ & 1720 & 12,000 & 1,320 & 42,800 & 96 \\
\hline & $7-25-91$ & 1215 & 5,000 & 1,050 & 14,200 & 97 \\
\hline & $8-15-91$ & 1345 & 6,000 & 1,560 & 25,300 & 93 \\
\hline & $8-28-91$ & 1225 & 600 & 624 & 1,010 & 98 \\
\hline & $9-25-91$ & 1130 & 400 & 304 & 328 & 99 \\
\hline & $6-10-92$ & 1430 & 600 & 299 & 484 & 100 \\
\hline & $6-23-92$ & 1500 & 5,400 & 640 & 9,330 & 95 \\
\hline & $7-13-92$ & 1550 & 13,400 & 1,180 & 42,700 & 97 \\
\hline & $7-31-92$ & 1330 & 5,500 & 706 & 10,500 & 98 \\
\hline & $8-13-92$ & 1315 & 8,500 & 1,990 & 45,700 & 97 \\
\hline & $8-27-92$ & 1500 & 3,900 & 1,120 & 11,800 & 96 \\
\hline & $9-9-92$ & 1515 & 250 & 252 & 170 & 100 \\
\hline
\end{tabular}



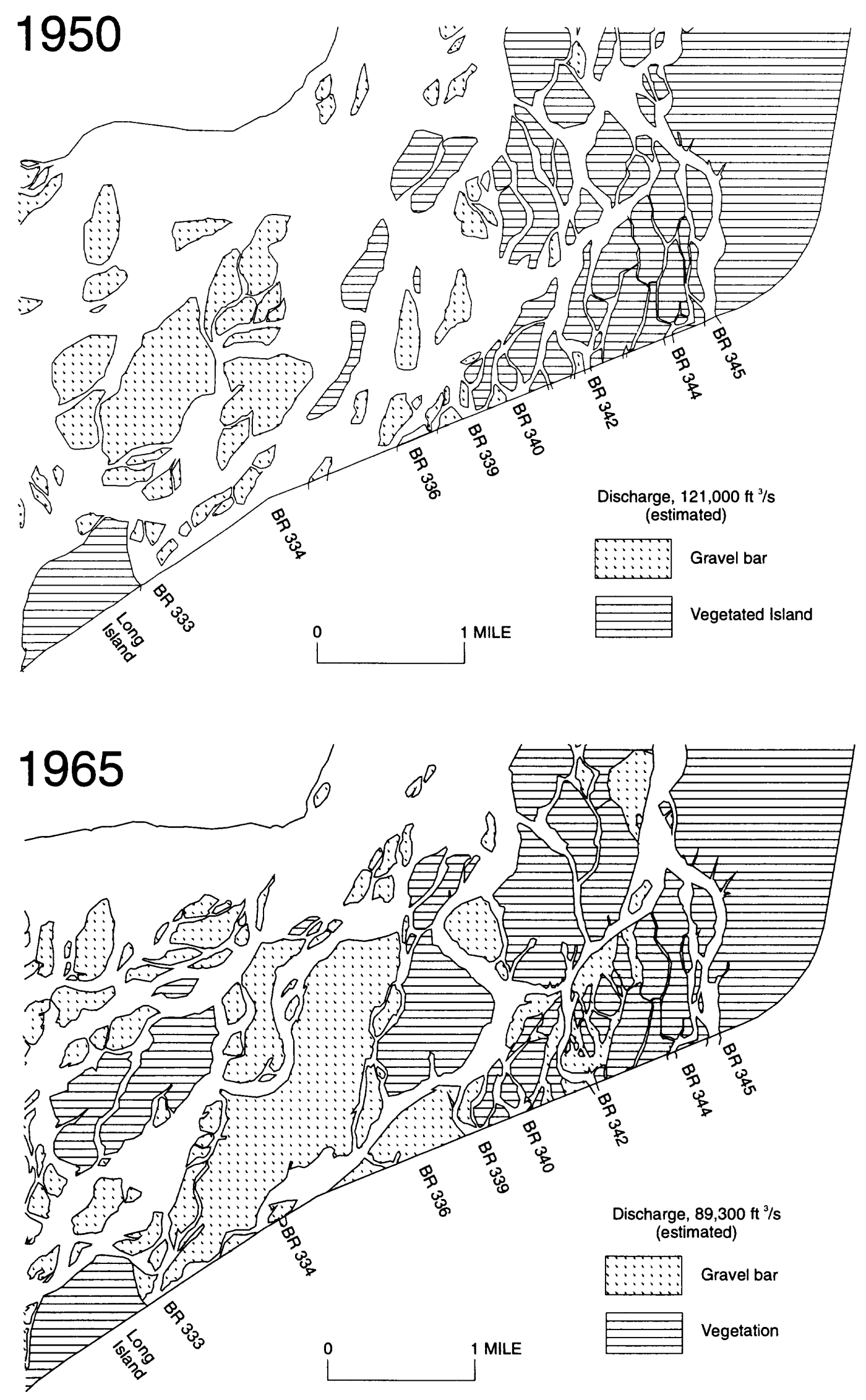

Figure 13. Maps of the Copper River near Long Island, based on aerial photographs taken from 1950-91. 

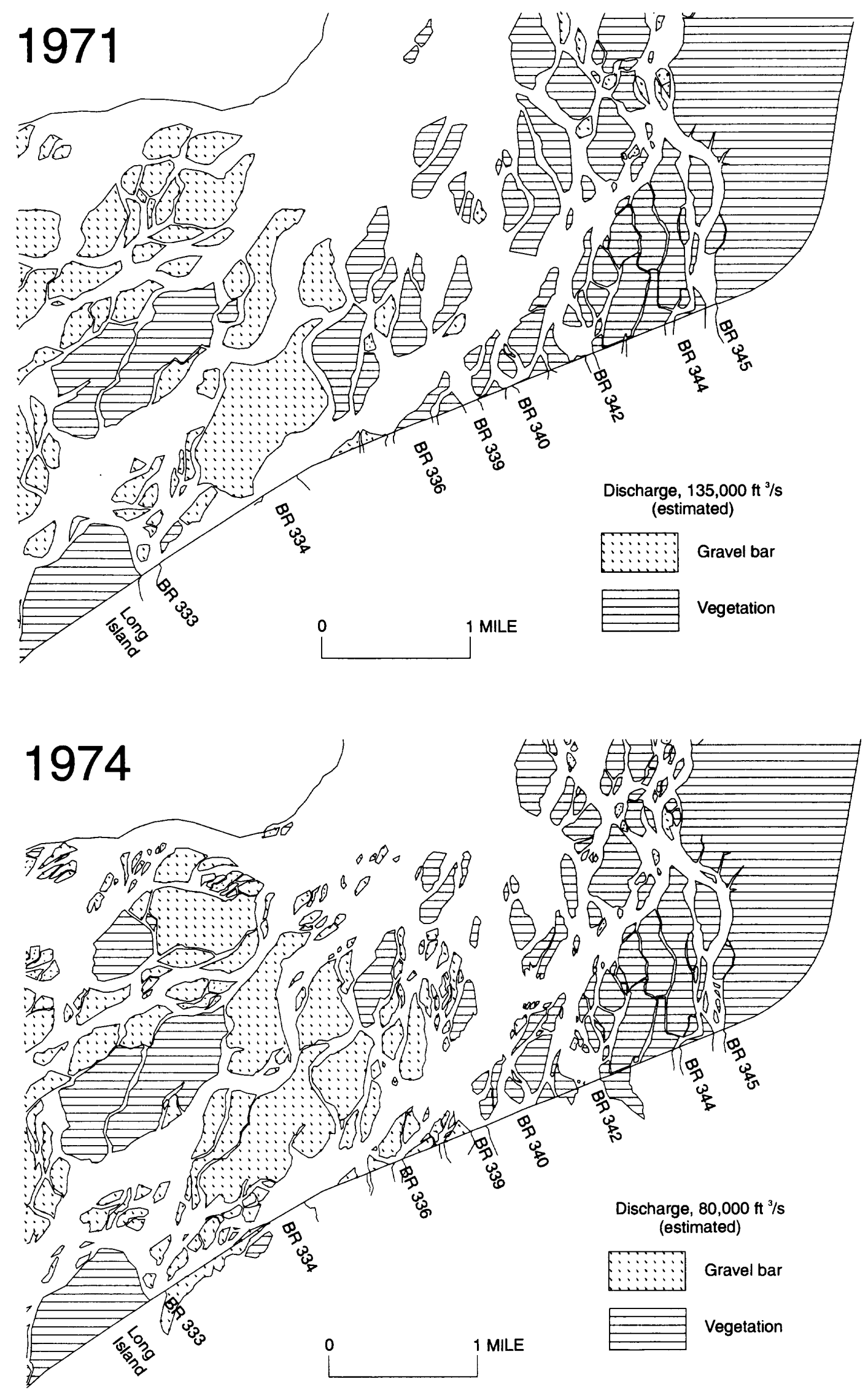

Figure 13. Continued. 

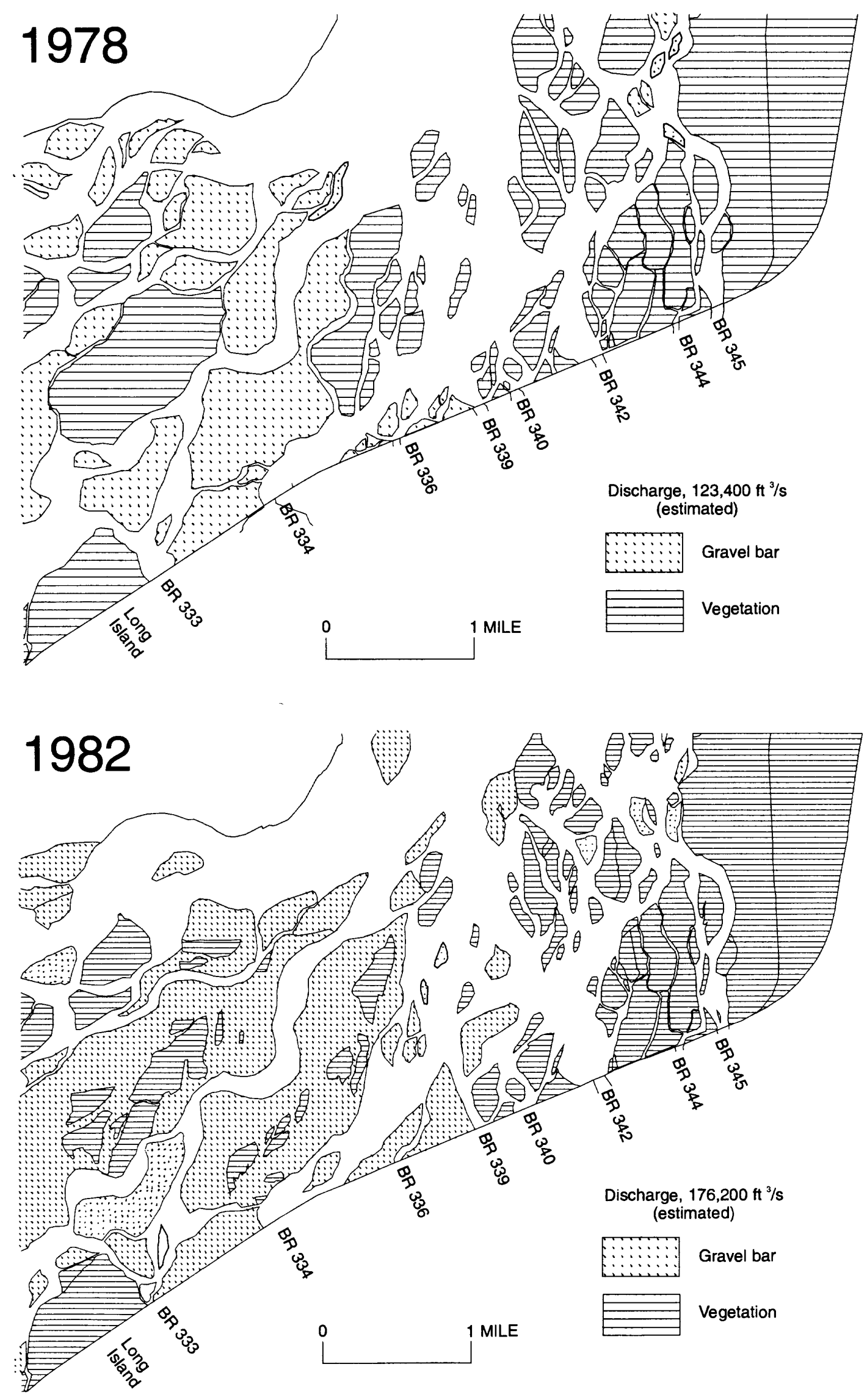

Figure 13. Continued. 

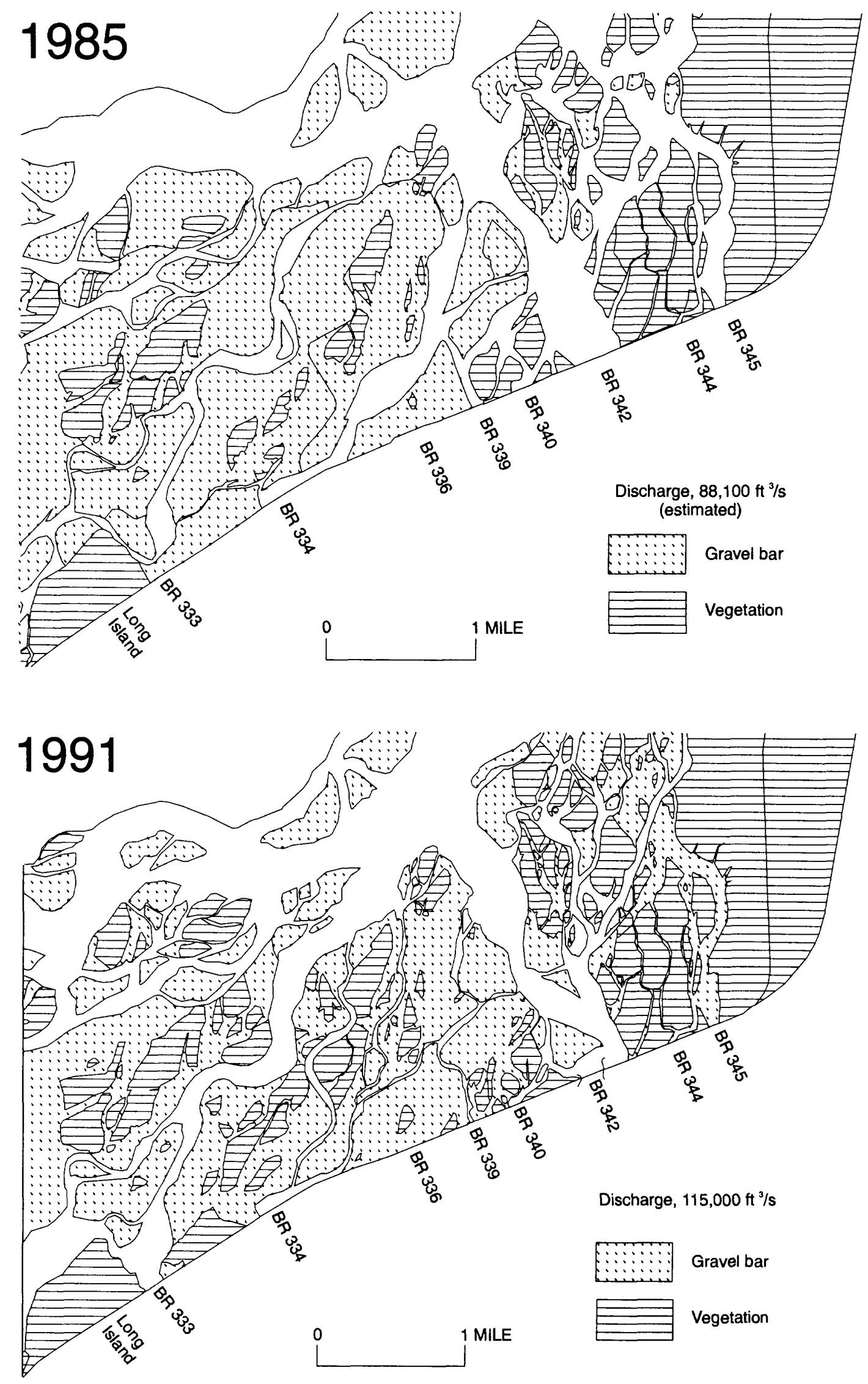

Figure 13. Continued. 


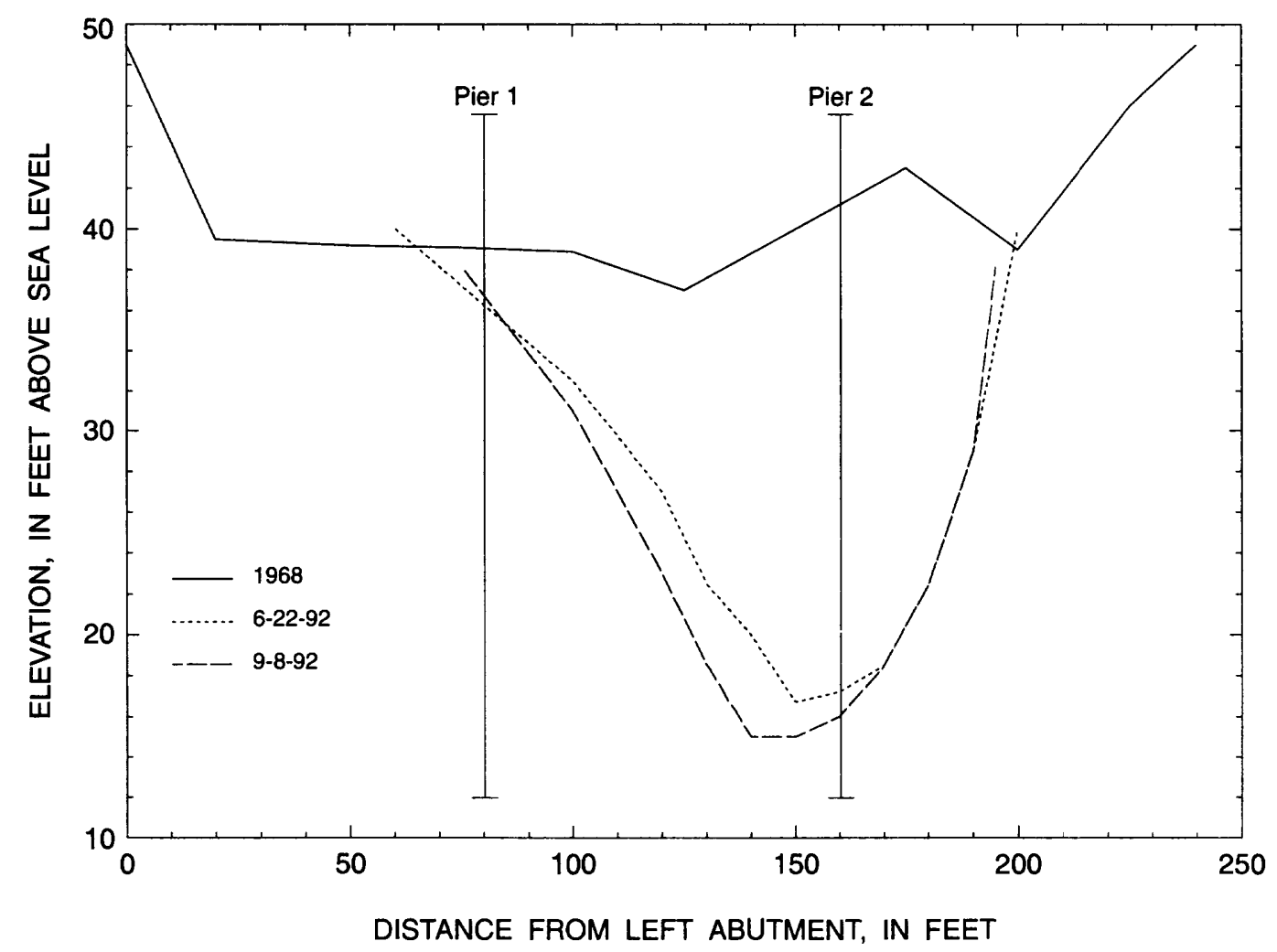

Figure 14. Cross sections of the Copper River, downstream side of Bridge 333.

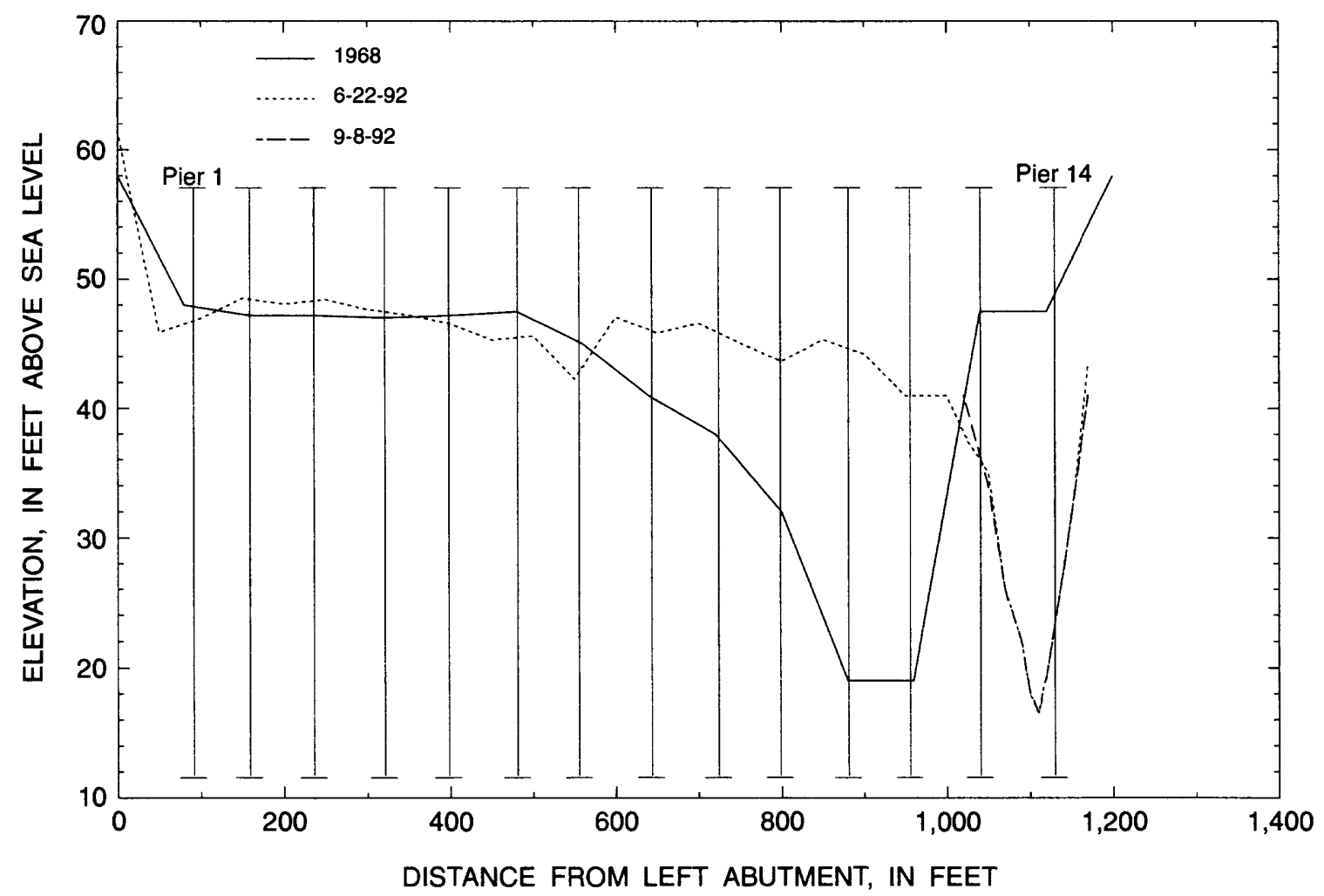

Figure 15. Cross sections of the Copper River, downstream side of Bridge 334 . 
Bridges 336, 339 and 340 are located at Miles 35.3, 35.8, and 36.1 respectively, of the Copper River Highway. The present bridges were constructed during 1976-78. Bridge 336 is $240 \mathrm{ft}$ long and is supported by two sets of steel piers spaced $80 \mathrm{ft}$ apart. Bridge 339 is $400 \mathrm{ft}$ long and is supported by four sets of steel piers spaced $80 \mathrm{ft}$ apart. Bridge 340 is $240 \mathrm{ft}$ long and is supported by two sets of steel piers spaced $80 \mathrm{ft}$ apart. The piers are the same type as those constructed at Bridges 333 and 334 . The design discharge of Bridge 336 is $8,500 \mathrm{ft}^{3} / \mathrm{s}$, that of Bridge 339 is $18,500 \mathrm{ft}^{3} / \mathrm{s}$, and that of Bridge 340 is $27,000 \mathrm{ft}^{3} / \mathrm{s}$.

During the open-water periods of 1991 and 1992, no flow was observed at Bridge 336. At Bridge 339, measured discharges ranged from about 10 to $5,400 \mathrm{ft}^{3} / \mathrm{s}$ and at Bridge 340, discharge ranged from 0 to $11,800 \mathrm{ft}^{3} / \mathrm{s}$ (table 9). The discharge at Bridge 339 represents less than 3 percent of the total flow past the Million Dollar Bridge and the discharge at Bridge 340 represents less than 5 percent of the total flow past the Million Dollar Bridge. All measured discharges were well below the design discharges. Measured suspended-sediment concentrations at Bridge 339 ranged from 212 to $2,230 \mathrm{mg} / \mathrm{L}$ and at Bridge 340 from 351 to $2,170 \mathrm{mg} / \mathrm{L}$ (table 10). Most of the sediment is finer than $0.062 \mathrm{~mm}$. No bedload or bed material samples were collected at these sites because the flow at these bridges was considered insignificant.

Table 9. Discharge of the Copper River at Bridges 339, 340, and the Million Dollar Bridge [Data values in cubic feet per second]

\begin{tabular}{|c|c|c|c|c|c|}
\hline \multirow[b]{2}{*}{ Date } & \multicolumn{2}{|c|}{ Bridge 339} & \multicolumn{2}{|c|}{ Bridge 340} & \multirow{2}{*}{$\begin{array}{c}\text { Million } \\
\text { Dollar Bridge } \\
\text { discharge }\end{array}$} \\
\hline & Discharge & $\begin{array}{l}\text { Percentage of } \\
\text { flow }^{1}\end{array}$ & Discharge & $\begin{array}{c}\text { Percentage of } \\
\text { flow }^{1}\end{array}$ & \\
\hline \multicolumn{6}{|l|}{1991} \\
\hline $6-18$ & 1,200 & 1 & 4,100 & 3 & 128,000 \\
\hline $7-1$ & 5,400 & 2 & 11,800 & 5 & 216,000 \\
\hline $7-24$ & 2,300 & 1 & 6,800 & 4 & 159,000 \\
\hline $8-13$ & 1,900 & 1 & 7,700 & 5 & 158,000 \\
\hline $8-28$ & 600 & 1 & 1,100 & 1 & 95,400 \\
\hline $9-12$ & 1,000 & 1 & 1,500 & 1 & 108,000 \\
\hline $9-23$ & 40 & $<1$ & 200 & $<1$ & 71,500 \\
\hline \multicolumn{6}{|l|}{1992} \\
\hline $6-8$ & 368 & 1 & 1,140 & 1 & 106,000 \\
\hline $6-22$ & 2,240 & 1 & 6,270 & 4 & 162,000 \\
\hline $7-13$ & 3,700 & 2 & 7,150 & 4 & 203,000 \\
\hline $7-28$ & 3,200 & 2 & 5,770 & 3 & 169,000 \\
\hline $8-11$ & 3,800 & 2 & 5,860 & 4 & 162,000 \\
\hline $8-24$ & 2,160 & 1 & 3,470 & 2 & 146,000 \\
\hline $9-8$ & 425 & $<1$ & 235 & $<1$ & 67,000 \\
\hline $9-18$ & $<10$ & $<1$ & 0 & -- & 40,000 \\
\hline
\end{tabular}

${ }^{1}$ Percentage of total flow at Million Dollar Bridge. 
Table 10. Suspended-sediment data for the Copper River at Bridges 339 and 340 [ft ${ }^{3} / \mathrm{s}$, cubic feet per second; mg/L, milligrams per liter; ton/d, ton per day]

\begin{tabular}{|c|c|c|c|c|c|c|}
\hline \multirow[b]{2}{*}{ Bridge } & \multirow[b]{2}{*}{ Date } & \multirow[b]{2}{*}{ Time } & \multirow{2}{*}{$\begin{array}{c}\text { Water } \\
\text { discharge } \\
\left(\mathrm{ft}^{3} / \mathrm{s}\right)\end{array}$} & \multicolumn{3}{|c|}{ Suspended sediment } \\
\hline & & & & $\begin{array}{c}\text { Concen- } \\
\text { tration } \\
(\mathrm{mg} / \mathrm{L})\end{array}$ & $\begin{array}{c}\text { Discharge } \\
\text { (ton/d) }\end{array}$ & $\begin{array}{c}\text { Percent } \\
\text { finer than } \\
0.062 \mathrm{~mm}\end{array}$ \\
\hline \multirow[t]{12}{*}{339} & $7-02-91$ & 1710 & 5,400 & 1,140 & 16,600 & 98 \\
\hline & $7-25-91$ & 1155 & 2,300 & 1,060 & 6,580 & 97 \\
\hline & $8-15-91$ & 1330 & 1,900 & 2,230 & 11,400 & -- \\
\hline & $8-28-91$ & 1130 & 600 & 634 & 1,030 & 100 \\
\hline & $9-23-91$ & 1115 & 40 & 212 & 23 & 98 \\
\hline & $6-10-92$ & 1415 & 300 & 439 & 356 & 98 \\
\hline & $6-23-92$ & 1430 & 2,100 & 654 & 3,710 & 94 \\
\hline & $7-13-92$ & 1510 & 4,400 & 1,150 & 13,700 & 98 \\
\hline & $7-28-92$ & 1200 & 3,200 & 878 & 7,580 & 90 \\
\hline & $8-13-92$ & 1300 & 3,800 & 2,170 & 22,300 & 96 \\
\hline & $8-27-92$ & 1430 & 2,200 & 1,260 & 7,480 & 89 \\
\hline & $9-9-92$ & 1525 & 400 & 412 & 445 & 100 \\
\hline \multirow[t]{13}{*}{340} & $6-20-91$ & 1600 & 4,100 & 786 & 8,700 & 91 \\
\hline & $7-02-91$ & 1705 & 11,800 & 1,320 & 42,100 & 96 \\
\hline & $7-25-91$ & 1150 & 6,800 & 1,040 & 19,100 & 98 \\
\hline & $8-15-91$ & 1310 & 7,700 & 1,370 & 28,500 & 95 \\
\hline & $8-28-91$ & 1100 & 1,100 & 707 & 2,100 & 99 \\
\hline & $9-25-91$ & 1100 & 200 & 372 & 201 & 100 \\
\hline & $6-10-92$ & 1400 & 1,100 & 425 & 1,260 & 96 \\
\hline & $6-23-92$ & 1400 & 6,000 & 676 & 11,000 & 91 \\
\hline & $7-13-92$ & 1430 & 7,200 & 1,160 & 22,600 & 97 \\
\hline & $7-28-92$ & 1130 & 5,500 & 1,030 & 15,300 & 93 \\
\hline & 8-13-92 & 1240 & 5,900 & 2,170 & 34,600 & 96 \\
\hline & $8-27-92$ & 1415 & 3,500 & 1,220 & 11,500 & 93 \\
\hline & $9-9-92$ & 1530 & 200 & 351 & 190 & 100 \\
\hline
\end{tabular}


Although analysis of the aerial photography (fig. 13) for these three bridges was somewhat difficult because of the differences in discharge, some general conclusions can still be drawn. From 1950 to 1985, there was probably flow through Bridge 336. However, no flow was observed at this site in 1991 or 1992, probably indicating some channel shift upstream from the bridge. In the vicinity of Bridges 339 and 340, the vegetated bars appear to have remained unchanged since 1950. Comparing the 1950 and the 1991 photography, in which the discharges are similar, indicates that gravel bars have formed upstream from Bridge 339.

In 1968, the mean bed elevation at Bridge 336 was $47.0 \mathrm{ft}$ and in 1993 it was $43.0 \mathrm{ft}$, indicating that $4 \mathrm{ft}$ of scour had occurred. The cross section surveyed in 1993 (fig. 16) showed that a distinct channel has formed on the right side of the bridge. At Bridge 339, two distinct channels have formed since 1968 (fig. 17): the major channel is on the right side of the bridge. The mean bed elevation from $1968(47.0 \mathrm{ft})$ to $1992(40.7 \mathrm{ft})$ indicates about $6.0 \mathrm{ft}$ of scour at this bridge. No significant scour occurred during 1992, similar to Bridges 333 and 334. At Bridge 340, a somewhat uniform stable channel has developed (fig. 18). The mean bed elevation from 1968 (46.3 ft) to 1992 (41.4 ft) indicates about $5 \mathrm{ft}$ of scour has occurred. Minor scouring and filling occurred at this site during 1992.

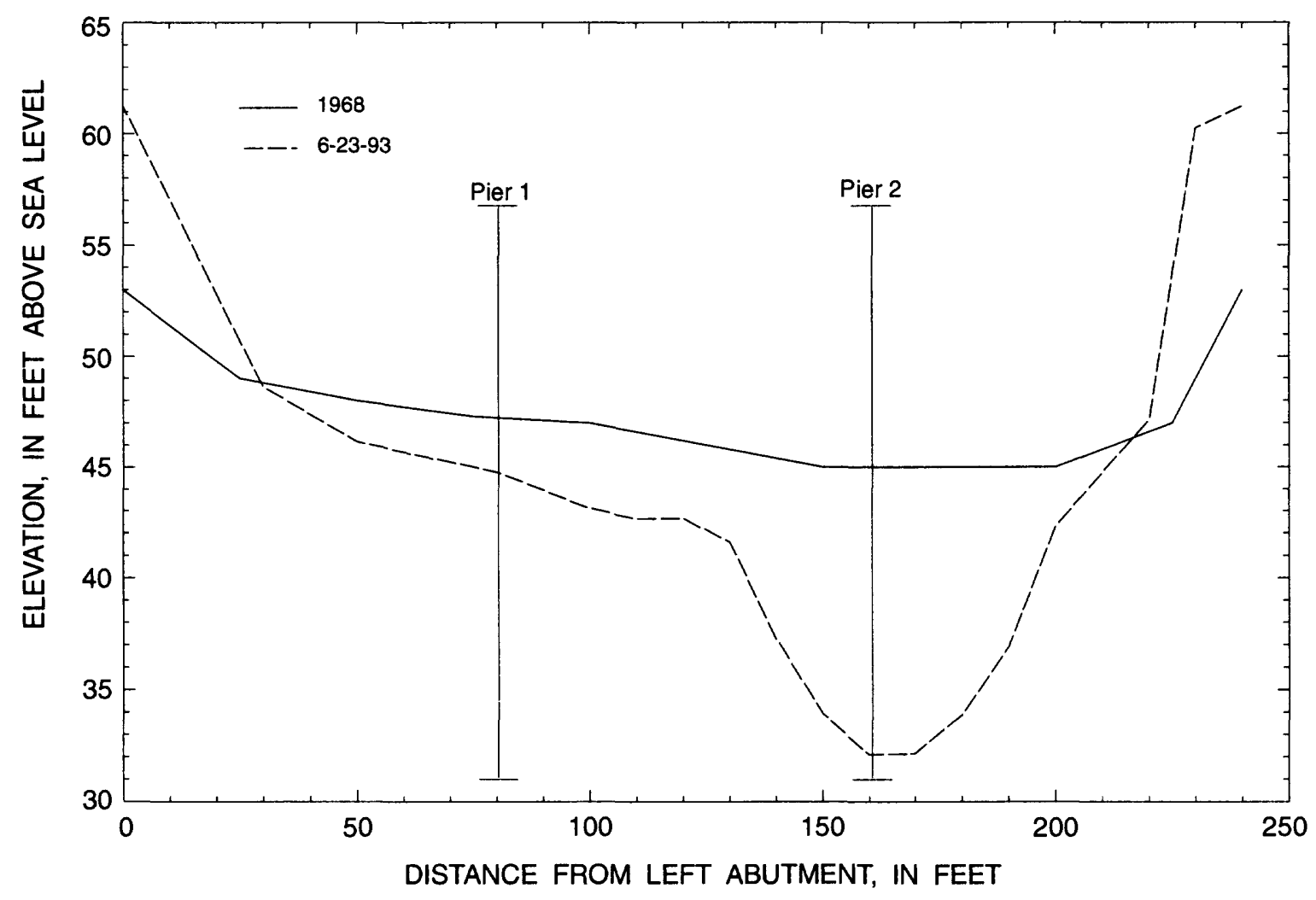

Figure 16. Cross sections of the Copper River, downstream side of Bridge 336. 


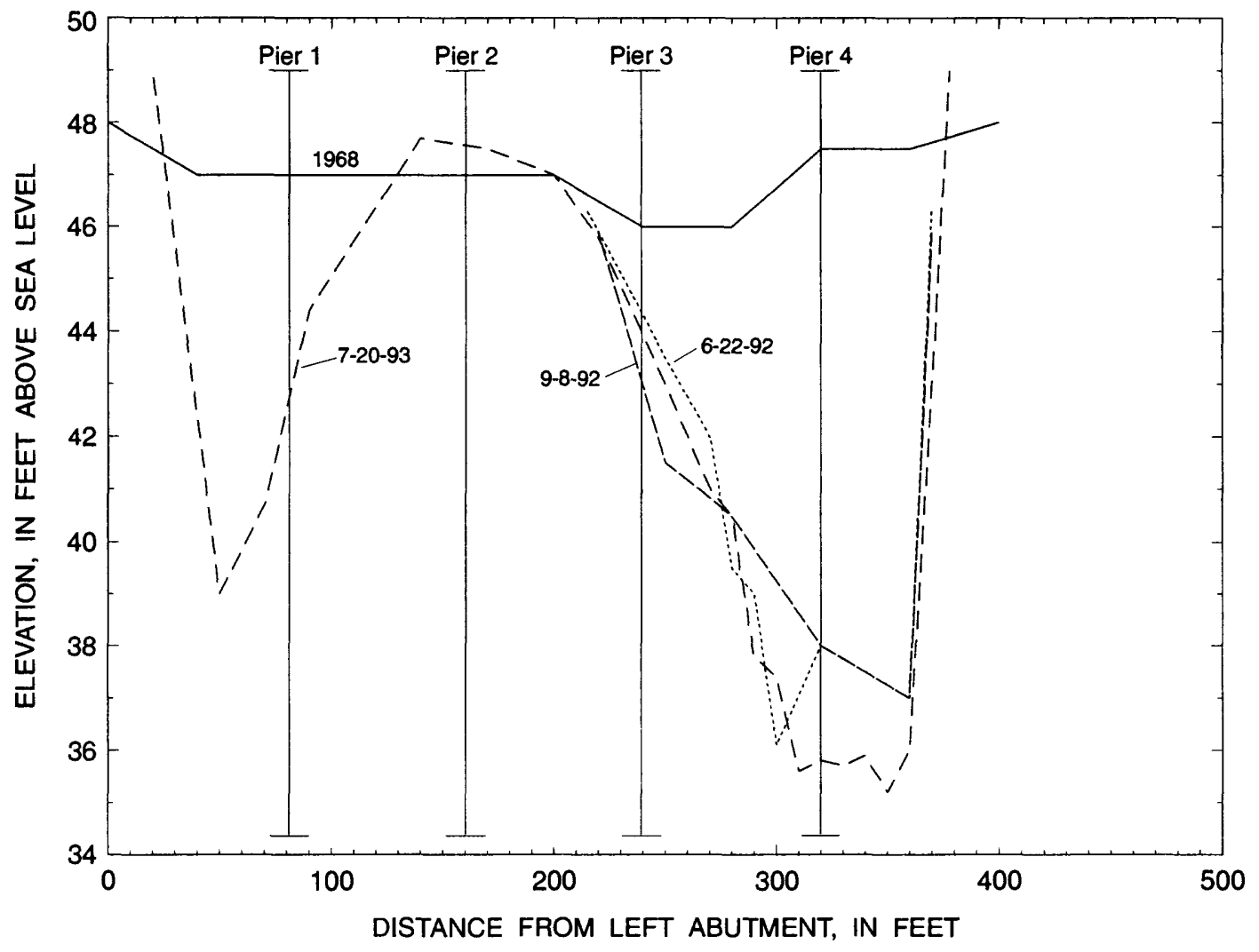

Figure 17. Cross sections of the Copper River, downstream side of Bridge 339.

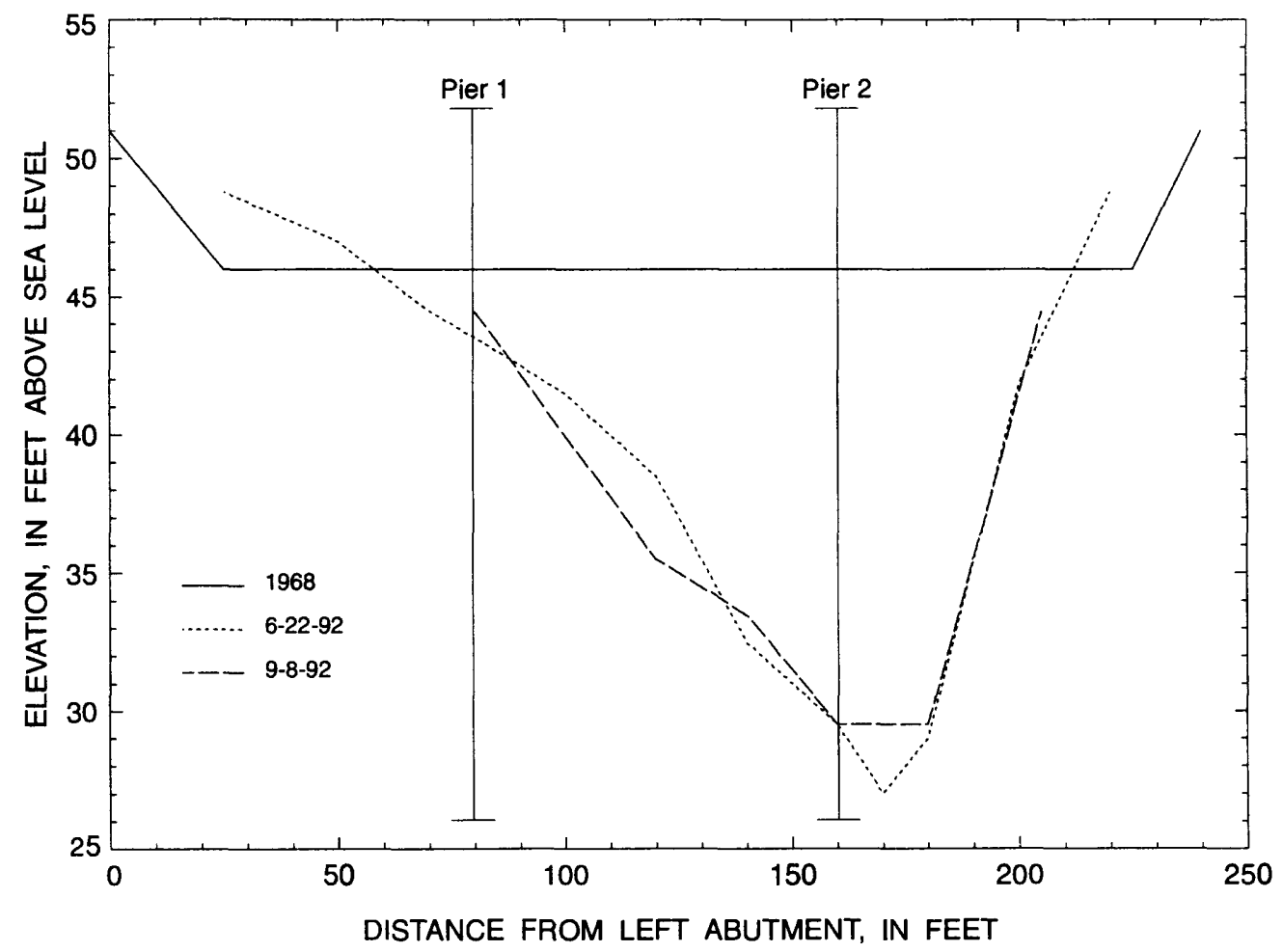

Figure 18. Cross sections of the Copper River, downstream side of Bridge 340 . 


\section{Bridge 342}

Bridge 342 is located at Mile 36.9 of the Copper River Highway. When this bridge was constructed in 1976-78, the original railroad bridge it replaced was $282 \mathrm{ft}$ long. The replacement bridge was $400 \mathrm{ft}$ long and was supported by four sets of steel piers spaced $80 \mathrm{ft}$ apart. The design discharge of the bridge was $34,200 \mathrm{ft}^{3} / \mathrm{s}$.

From 1950 to 1991, significant channel changes have taken place at this site. In 1950 and 1965, the channel leading to Bridge 342 was relatively small (fig. 13) and no major channel changes had occurred near the bridge. Comparison of 1965 and 1971 photography (fig. 13) however, shows a distinct widening of the approach channel to the bridge. This change may have been caused by the 1971 peak discharge of $265,000 \mathrm{ft}^{3} / \mathrm{s}$ at the Copper River at Chitina (about $65 \mathrm{mi}$ upstream from the Million Dollar Bridge), which was the highest recorded peak for the years 1950 to 1971 (table 11 ).

Table 11. Ranked peak discharges of the Copper River near Chitina (station No. 15212000), 1951-90 [Discharge values in cubic feet per second]

\begin{tabular}{|c|c|c|c|c|c|c|c|c|}
\hline Rank & $\begin{array}{l}\text { Water } \\
\text { year }\end{array}$ & Discharge & Rank & $\begin{array}{l}\text { Water } \\
\text { year }\end{array}$ & Discharge & Rank & $\begin{array}{l}\text { Water } \\
\text { year }\end{array}$ & Discharge \\
\hline 1 & 1981 & 380,000 & 14 & 1958 & 172,000 & 26 & 1952 & 159,000 \\
\hline 2 & 1971 & 265,000 & 15 & 1978 & 172,000 & 27 & 1962 & 155,000 \\
\hline 3 & 1951 & 220,000 & 16 & 1960 & 169,000 & 28 & 1967 & 154,000 \\
\hline 4 & 1989 & 212,000 & 17 & 1977 & 168,000 & 29 & 1965 & 153,000 \\
\hline 5 & 1990 & 208,000 & 18 & 1984 & 168,000 & 30 & 1961 & 152,000 \\
\hline 6 & 1976 & 200,000 & 19 & 1963 & 166,000 & 31 & 1973 & 151,000 \\
\hline 7 & 1974 & 199,000 & 20 & 1959 & 165,000 & 32 & 1957 & 148,000 \\
\hline 8 & 1975 & 195,000 & 21 & 1987 & 165,000 & 33 & 1970 & 144,000 \\
\hline 9 & 1985 & 188,000 & 22 & 1972 & 163,000 & 34 & 1983 & 144,000 \\
\hline 10 & 1988 & 186,000 & 23 & 1980 & 161,000 & 35 & 1966 & 140,000 \\
\hline 11 & 1986 & 178,000 & 24 & 1968 & 160,000 & 36 & 1964 & 129,000 \\
\hline 12 & 1982 & 174,000 & 25 & 1969 & 160,000 & 37 & 1956 & 124,000 \\
\hline 13 & 1979 & 173,000 & & & & & & \\
\hline
\end{tabular}

Photographs taken in 1971, 1974, and 1978 (fig. 13) do not show any additional significant channel changes, although relatively high peak discharges occurred at Chitina in 1974, 1975, and 1976 (table 11). After bridge construction was completed in 1978, no scour problems were noted at the bridge by ADOT\&PF personnel until 1981.

In August 1981, the peak discharge of record occurred at Chitina (table 11). This peak discharge of $380,000 \mathrm{ft}^{3} / \mathrm{s}$ exceeded the previous peak at Chitina by $115,000 \mathrm{ft}^{3} / \mathrm{s}$. As a result of this flood, the Copper River Highway was breached at Bridge 342 (Cordova Times, 1983). Comparison of 1978 and 1982 photography (fig. 13) clearly shows the erosion and widening of the approach channel. The approach continued to widen between 1985 and 1991 (fig. 13) and may have been caused by the flood peaks at Chitina in 1989 and 1990, which were the fourth and fifth highest peaks of record. 
Beginning in 1982, the ADOT\&PF began to monitor the streambed at Bridge 342 on a regular basis. As expected, significant contraction scour occurred because of the increased flow through the width of the bridge (fig. 19). The channel continually scoured and filled and as much as $54 \mathrm{ft}$ of scour occurred from 1968 to 1985 at one point in the channel. From 1982 to 1987, the mean bed elevation of the channel decreased from $36.6 \mathrm{ft}$ to $22.0 \mathrm{ft}$ (table 12). Concern for the safety and integrity of the bridge led ADOT\&PF to make major repairs to the structure in 1987. These repairs consisted of lengthening the bridge at each end by $240 \mathrm{ft}$ (480 ft total) and constructing spur dikes at the left and right upstream abutments. Construction was completed in November 1988.

After construction, the first cross section at Bridge 342 was obtained in August 1989. The mean bed elevation was $46.3 \mathrm{ft}$. High water of 1989 overtopped and destroyed the left bank upstream spur dike (fig. 20). The flow of the Copper River was directed at the highway embankment and then flowed westward under the bridge. This resulting change in flow direction caused considerable scour on the right side of the channel (fig. 21A) and lowered the mean bed elevation to $34.9 \mathrm{ft}$. In 1990-91, the spur dikes were rebuilt to a higher elevation. Since that time, the right side of the channel continued to scour during 1991, but appeared fairly stable during 1992 (fig. 21B). The left side of the channel filled in during 1991, but began to scour in 1992 (fig. 21B). Scour and fill are probably due to the effect of the spur dike on the approach channel to the bridge. From September 1991 to September 1992, the channel began to shift and align itself with the bridge opening (fig. 22).

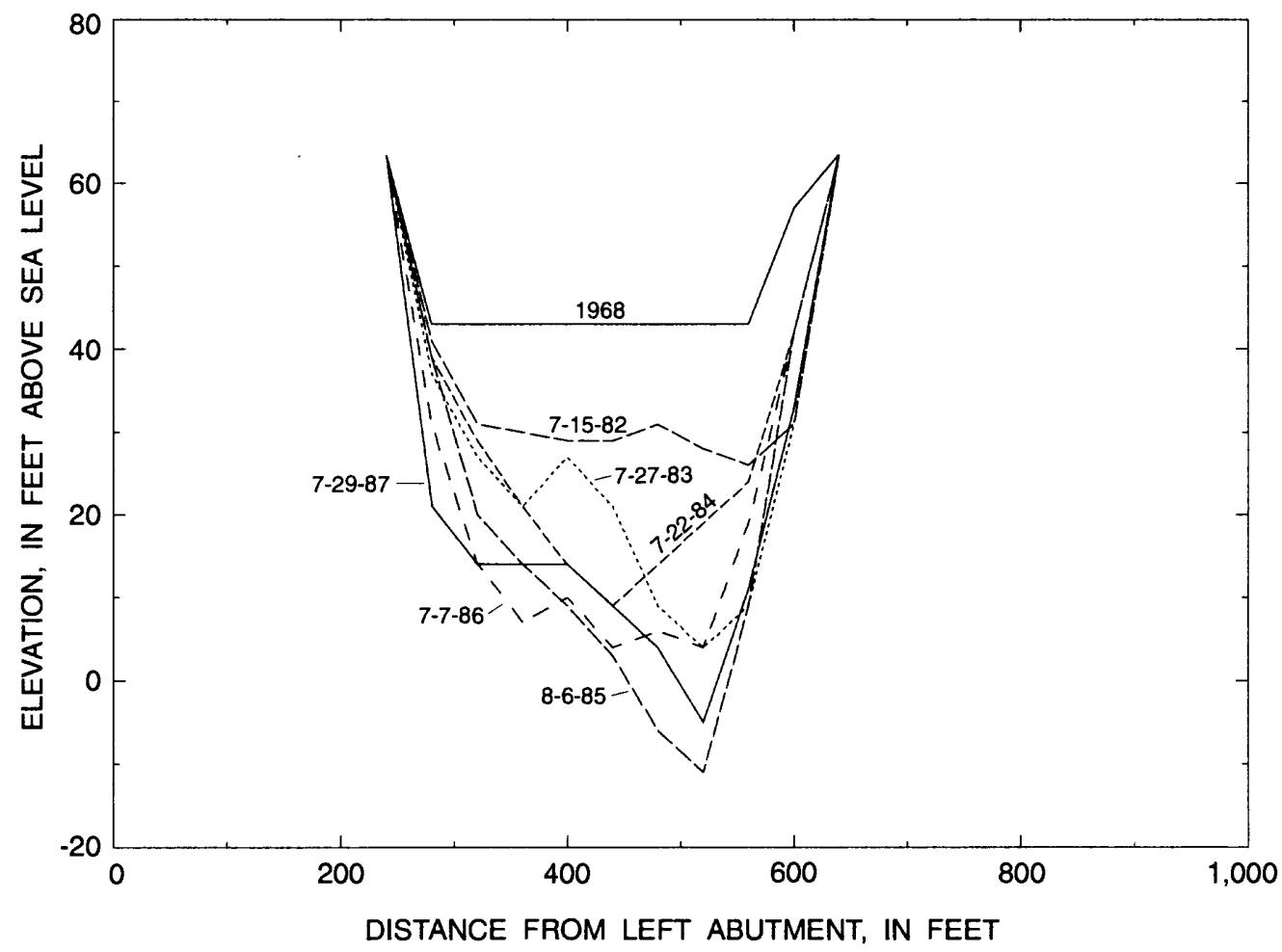

Figure 19. Cross sections of the Copper River, downstream side of Bridge 342, 1968-87. 
Table 12. Changes in mean bed elevation of the Copper River at Bridge 342, 1968-92 [All values in feet]

\begin{tabular}{cccc}
\hline Date & $\begin{array}{c}\text { Mean bed } \\
\text { elevation }\end{array}$ & $\begin{array}{c}\text { Change in } \\
\text { mean bed } \\
\text { elevation }\end{array}$ & $\begin{array}{c}\text { Minimum bed } \\
\text { elevation }\end{array}$ \\
\hline 1968 & 48.0 & -- & 43.0 \\
$7-15-82$ & 36.6 & -11.4 & 26.0 \\
$7-27-83$ & 28.4 & -8.2 & 4.0 \\
$7-22-84$ & 30.7 & +2.3 & 9.0 \\
$8-6-85$ & 22.4 & -8.3 & -11.0 \\
$7-7-86$ & 24.0 & +1.6 & 4.0 \\
$7-29-87$ & 22.0 & -2.0 & -5.0 \\
& After bridge lengthening & \\
\hline $8-89$ & 46.3 & -- & 32.0 \\
$5-10-90$ & 39.6 & -6.7 & 26.0 \\
$6-15-90$ & 34.9 & -4.7 & 14.0 \\
& After new spur dike & \\
\hline $6-7-91$ & 37.5 & +2.6 & 27.5 \\
$9-12-91$ & 41.3 & +3.8 & 20.3 \\
$9-18-92$ & 32.5 & -8.8 & 20.7 \\
\hline
\end{tabular}

${ }^{1}$ Mean bed elevation is based on a width of $400 \mathrm{ft}$ before August 1989 and a width of $880 \mathrm{ft}$ from August 1989 to September 1992

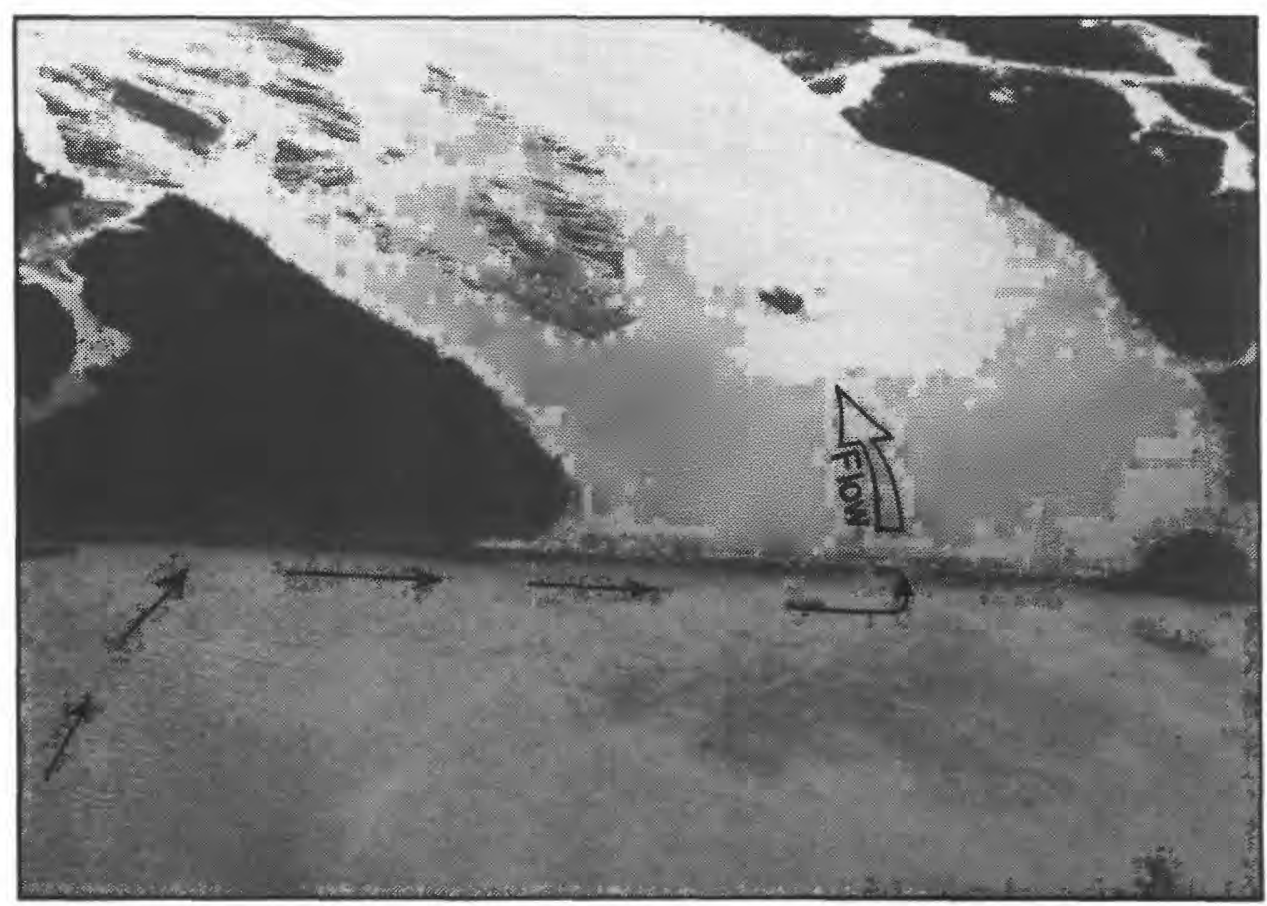

Figure 20. Bridge 342 on the Copper River Highway, looking downstream, September 1989. [Photograph from Mark Miles, Alaska Department of Transportation and Public Facilities.] 

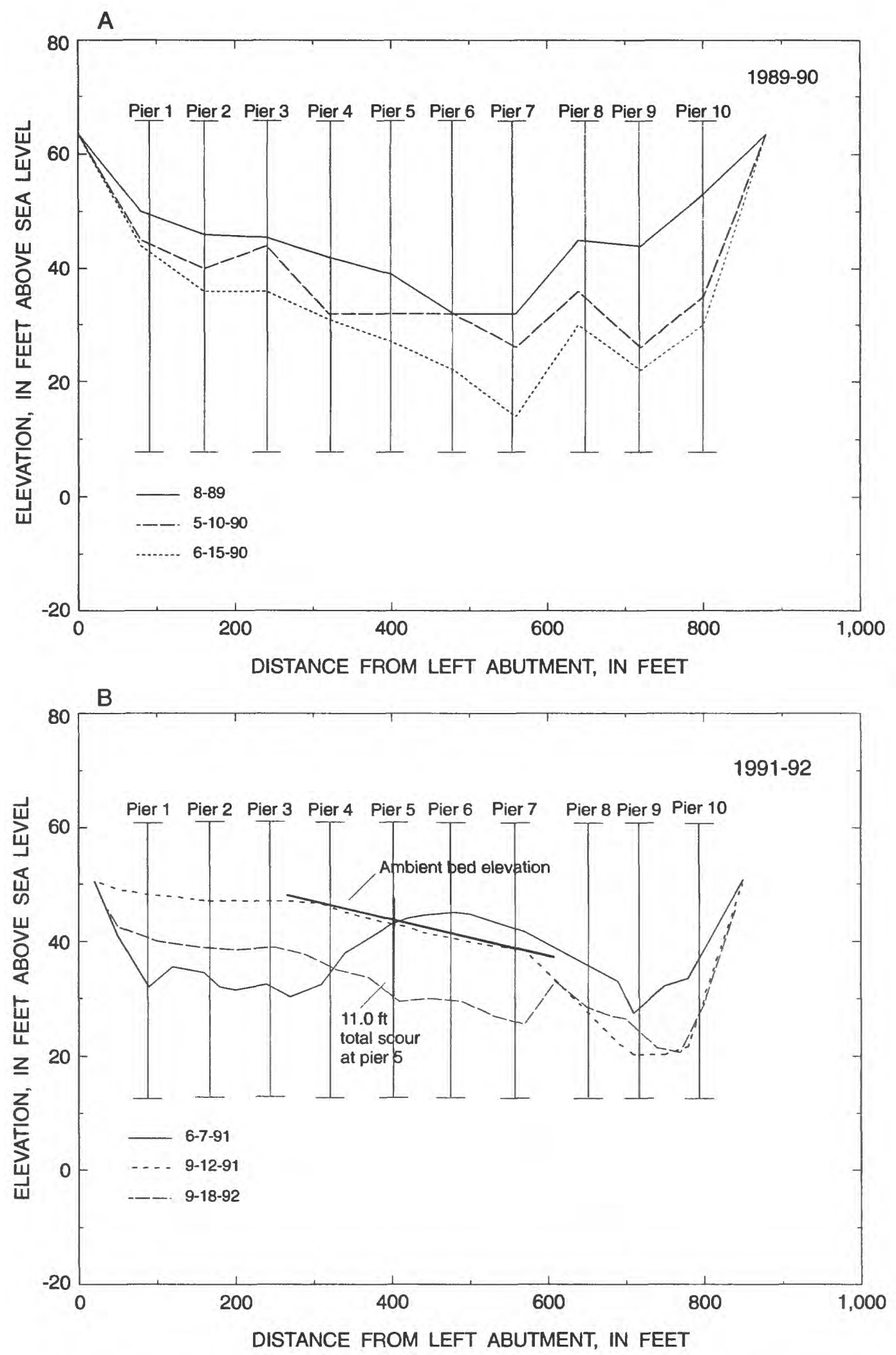

Figure 21. Cross sections of the Copper River, downstream side of Bridge 342, 1989-90 and 1991-92. 

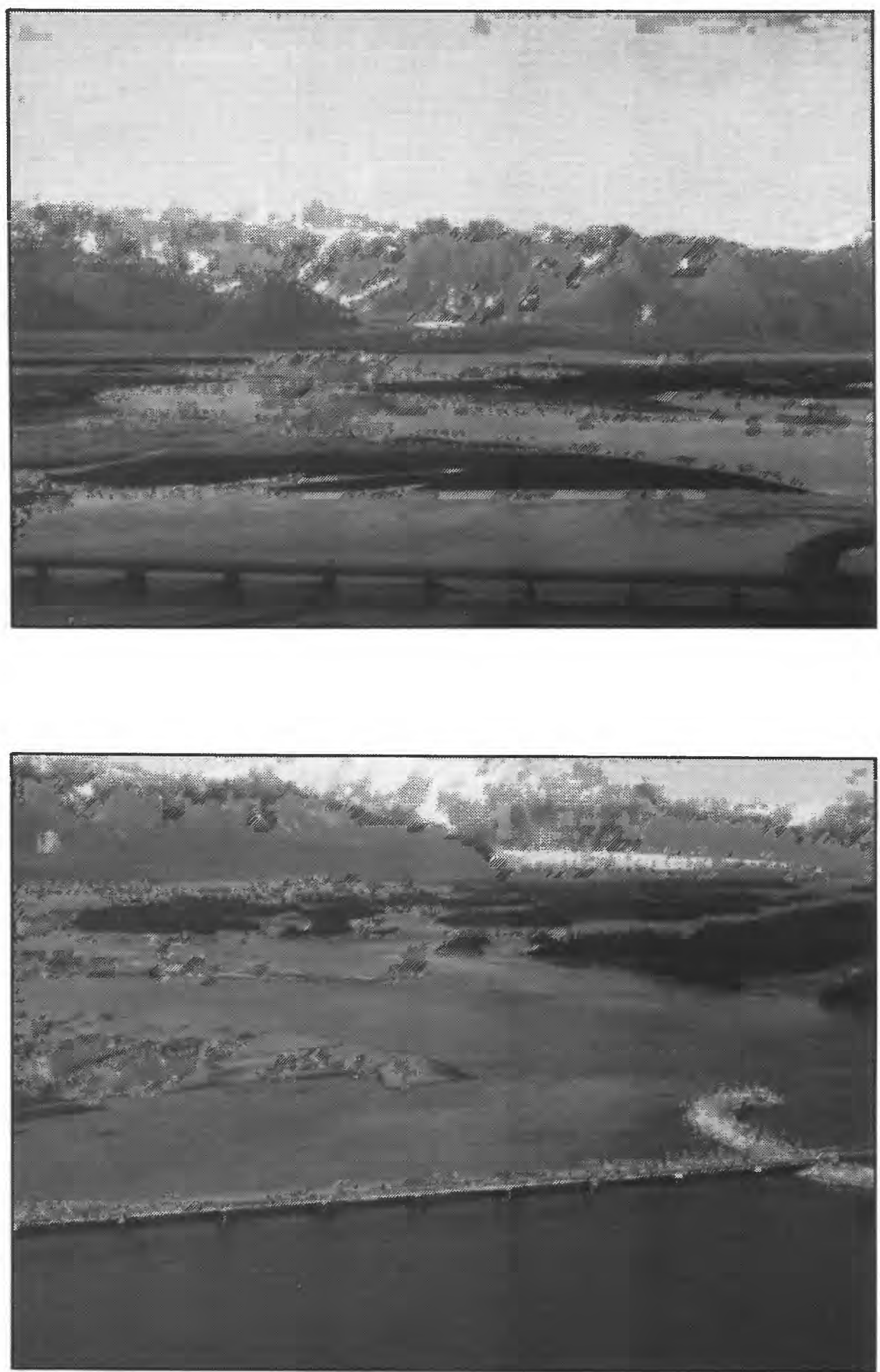

Figure 22A. Bridge 342 on the Copper River Highway, looking upstream; top, September 1991; bottom, September 1992. 

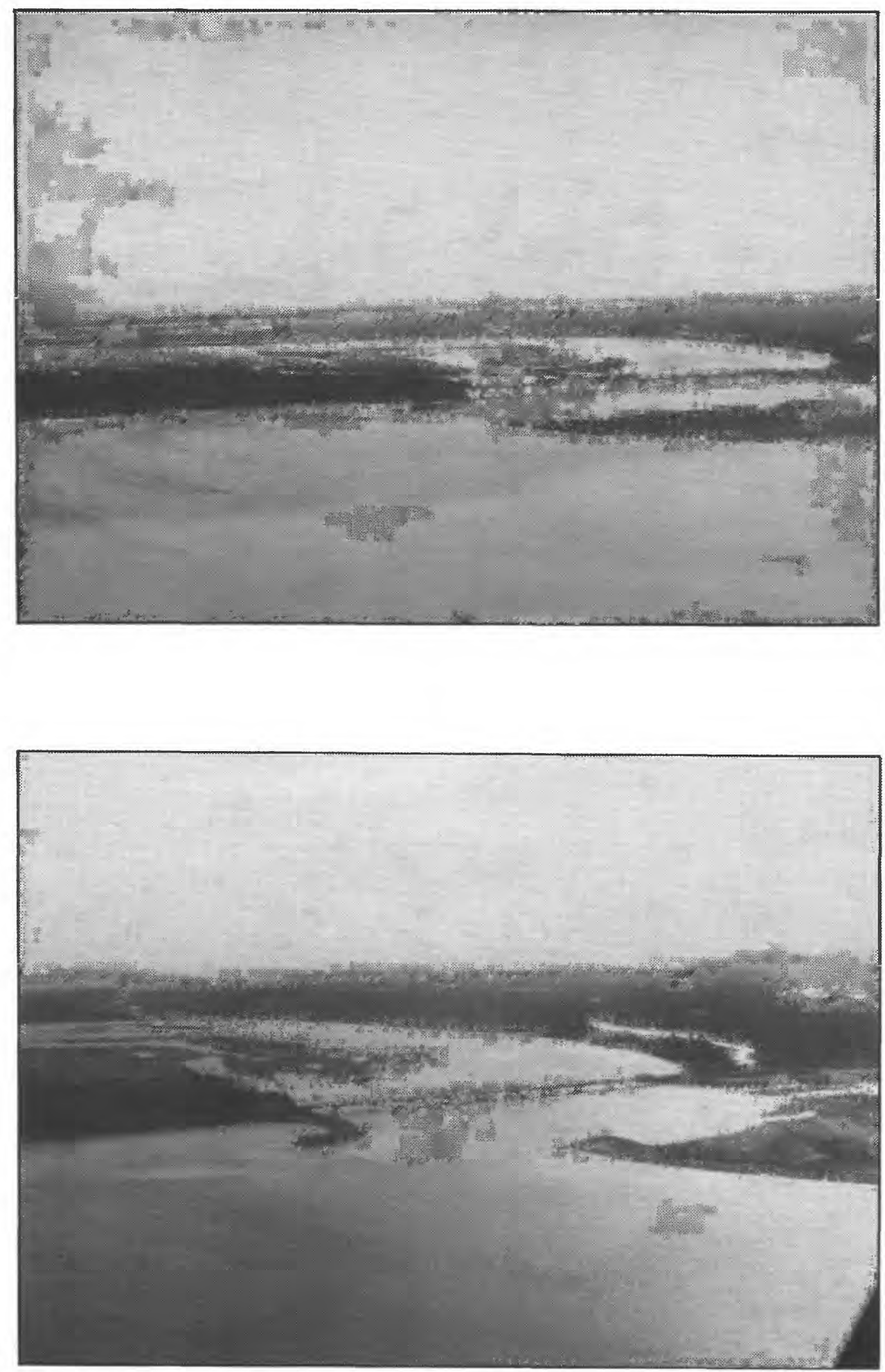

Figure 22B. Bridge 342 on the Copper River Highway, looking downstream; top, September 1991; bottom, September 1992. 
During the open-water periods of 1991 and 1992, discharge at Bridge 342 ranged from 13,400 to $91,400 \mathrm{ft}^{3} / \mathrm{s}$ (table 13). These discharges represent between 33 and 67 percent of the total flow of the Copper River past the Million Dollar Bridge indicating that a major channel has formed in the vicinity of Bridge 342. Suspended-sediment concentrations ranged from 262 to $2,316 \mathrm{mg} / \mathrm{L}$. Most of the sediment is finer than $0.062 \mathrm{~mm}$ (table 14). Measured bedload discharge ranged from 1,000 to 14,700 ton/d (table 13). The median diameter, $\mathrm{d}_{50}$, of the bedload ranged from 0.8 to $16.0 \mathrm{~mm}$. Although the relatively large range in bedload transport probably reflects the corresponding range in water discharge, the continuing erosion of the gravel bar just upstream from the bridge may also be supplying additional bedload. Most of the bed material is composed of coarse to very coarse gravel (fig. 23) and had a median diameter, $\mathrm{d}_{50}$, of $32 \mathrm{~mm}$.

During the 1992 open-water season, $11.0 \mathrm{ft}$ of scour was measured near pier 5 (fig. 21B). Because the channel at Bridge 342 is undergoing constant change and realignment, this scour is considered to be aggradation and degradation of the channel. Thus, the local scour equations were not tested at this bridge.

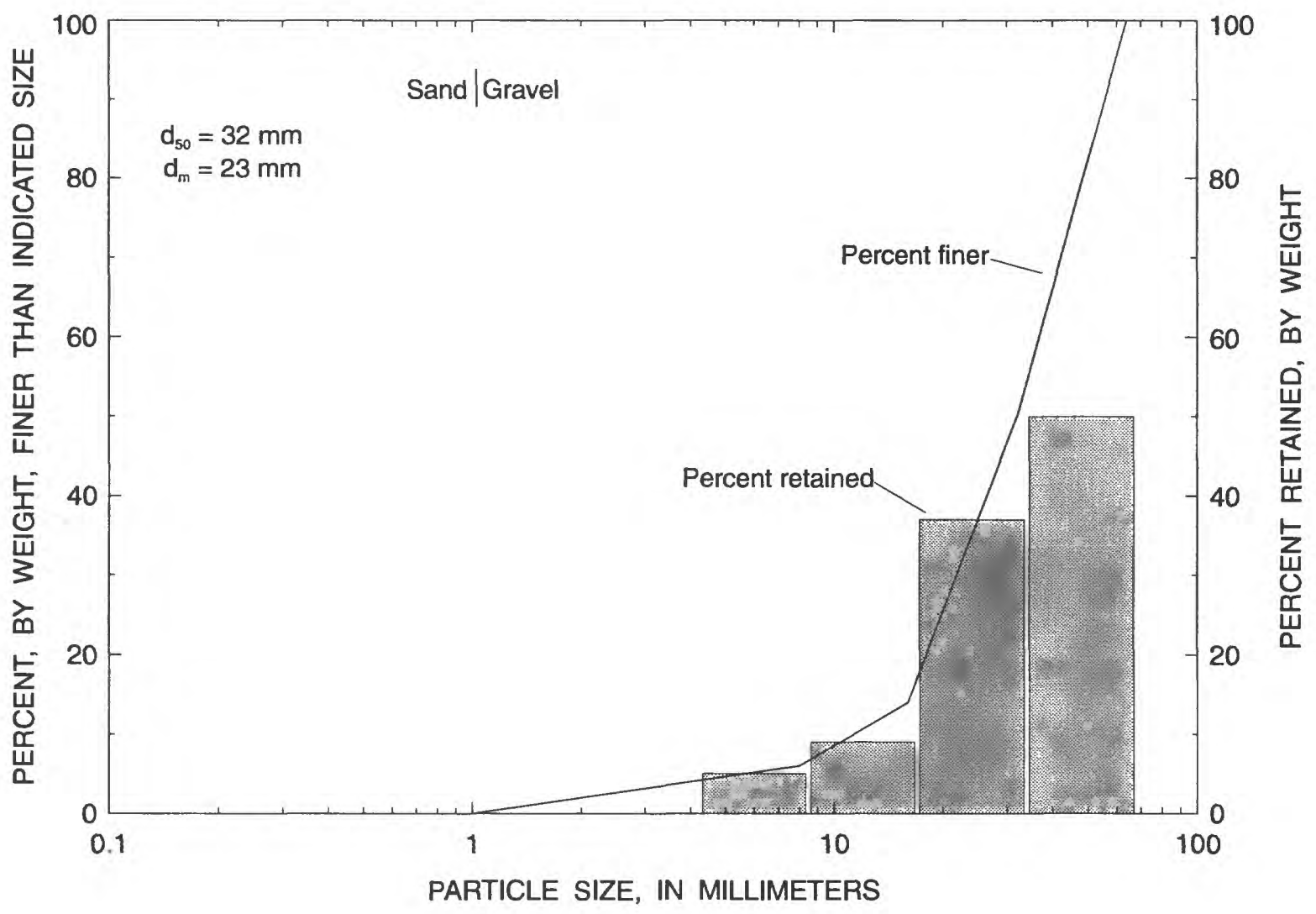

Figure 23. Particle-size distribution, median diameter $\left(d_{50}\right)$, and mean diameter $\left(d_{m}\right)$, of bed material, Copper River at Bridge 342. 


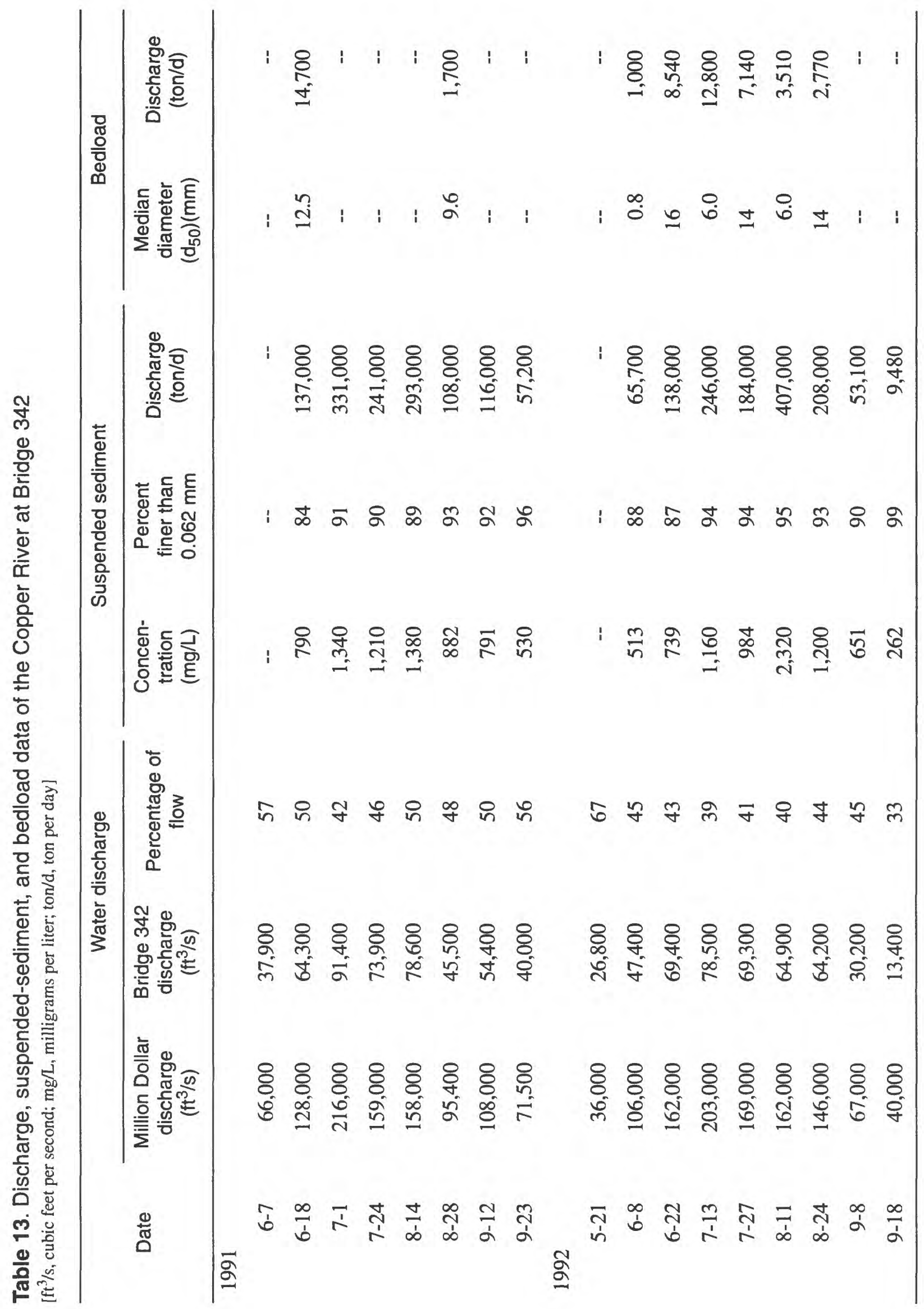




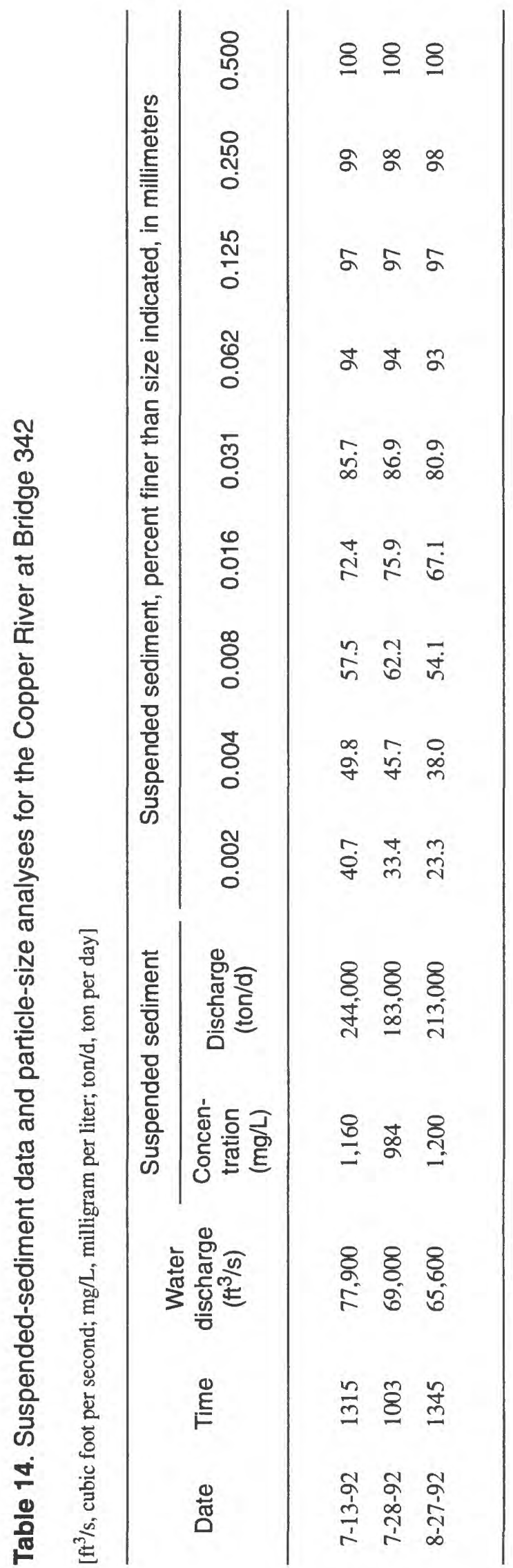




\section{Bridges 344 and 345}

Bridges 344 and 345 are located at Miles 37.4 and 37.8, respectively, of the Copper River Highway. The present bridges were constructed during 1976-78. Bridge 344 is $400 \mathrm{ft}$ long and is supported by four sets of steel piers spaced $80 \mathrm{ft}$ apart. Bridge 345 is $480 \mathrm{ft}$ long and is supported by five sets of steel piers spaced $80 \mathrm{ft}$ apart. The design discharge of Bridge 344 is $8,600 \mathrm{ft}^{3} / \mathrm{s}$ and that of Bridge 345 is $44,000 \mathrm{ft}^{3} / \mathrm{s}$.

During the open-water periods of 1991 and 1992, flow was observed and measured one time at Bridge $344\left(100 \mathrm{ft}^{3} / \mathrm{s}\right)$ and twice at Bridge $345\left(318\right.$ and $\left.1,100 \mathrm{ft}^{3} / \mathrm{s}\right)$. These flows represent less than 1 percent of the flow past the Million Dollar Bridge and occurred when the discharge at the Million Dollar Bridge was more than $200,000 \mathrm{ft}^{3} / \mathrm{s}$, which is considered a high flow. The one suspended-sediment sample collected at Bridge 345 had a concentration of $991 \mathrm{mg} / \mathrm{L}$.

Analysis of the aerial photography indicates that from 1950 to 1985 flow was present in the channels located at Bridges 344 and 345, even during 1965, 1974, and 1985, which were years of relatively low discharge. Thus, flow was most likely present at these two bridges on a continuous basis. However, because the flow was detected at these bridges only during high-flow periods in 1991-92, a channel located upstream (not shown in the photography) may have shifted and diverted flow away from these channels sometime between 1985 and 1991.

Comparison of cross sections at Bridge 344 indicates some scour in the main channel from 1968 to 1991 (fig. 24) and the maximum scour is approximately $5 \mathrm{ft}$. The mean bed elevation at this bridge decreased from $52.1 \mathrm{ft}$ in 1968 to $50.0 \mathrm{ft}$ in 1991. At Bridge 345, the center of the channel has filled but the left and right parts of the channel have scoured (fig. 25). The mean bed elevation, $48.0 \mathrm{ft}$, has remained constant from 1968 to 1991.

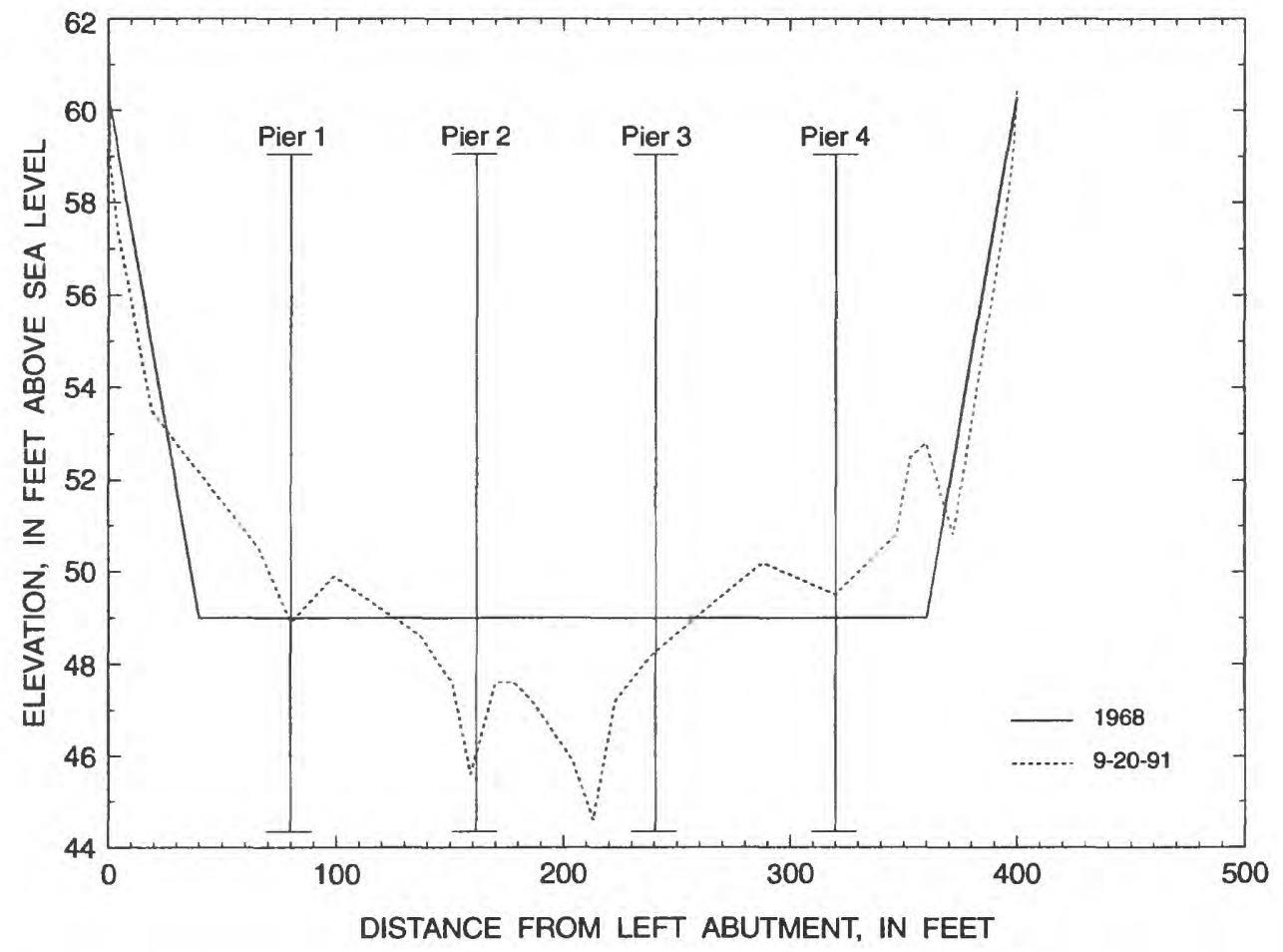

Figure 24. Cross sections of the Copper River, downstream side of Bridge 344. 


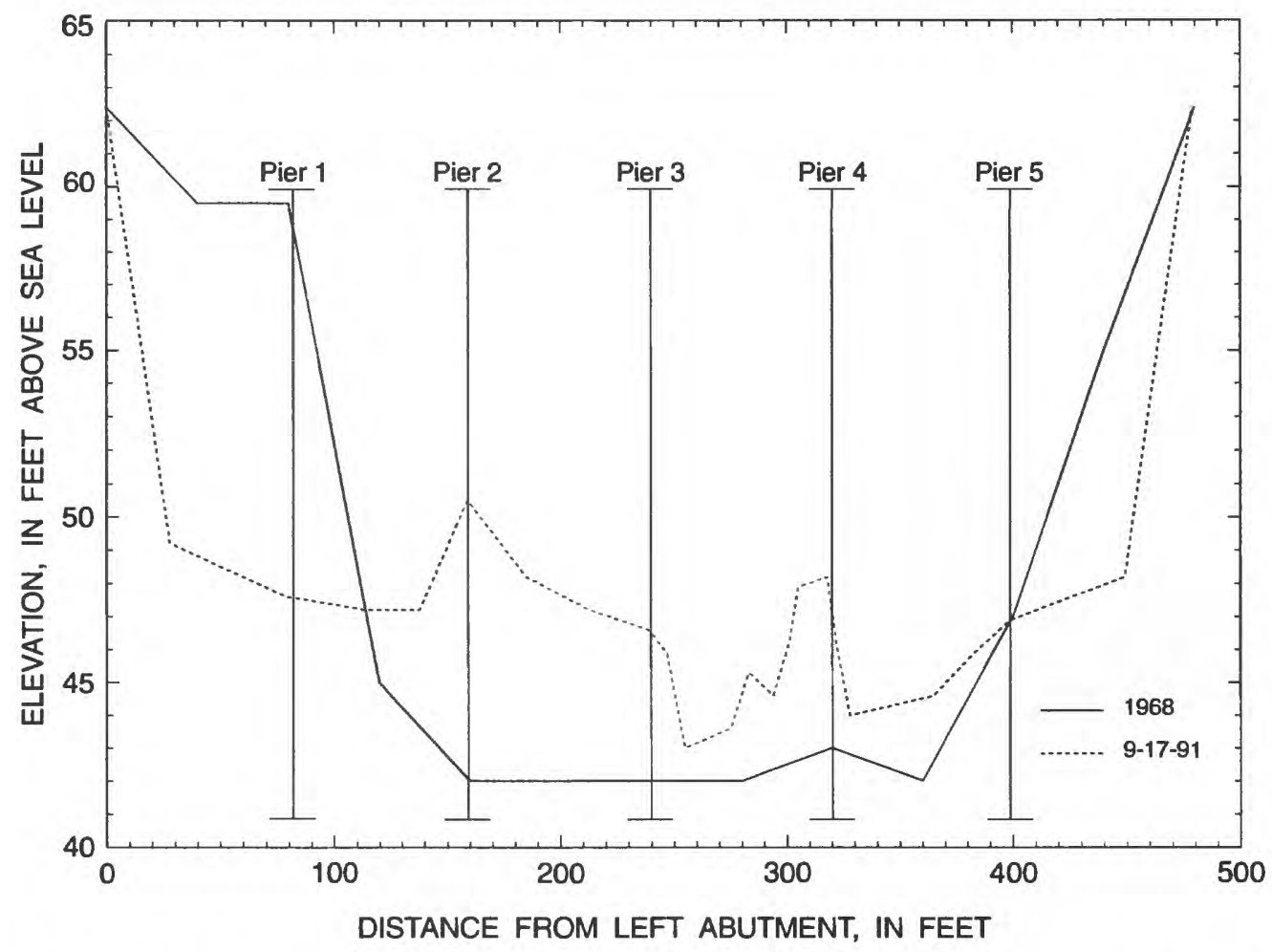

Figure 25. Cross sections of the Copper River, downstream side of Bridge 345 .

\section{Million Dollar Bridge}

The Million Dollar Bridge was constructed in 1909-10. Builders of the bridge were presented with different and unusual hydrologic conditions. The bridge had to be located between Childs Glacier and Miles Glacier (fig. 1). Miles Glacier, upstream from the bridge, continually calves during the summer months, sending large icebergs downstream. In addition, the Copper River is subject to rapid or instantaneous flooding resulting from the breakout of glacier dam lakes such as Van Cleve Lake (fig. 1).

To meet these conditions, three massive concrete piers were built on pneumatic caisson foundations 70 by $32 \mathrm{ft}$ in size. The caissons were placed at a depth of $44 \mathrm{ft}$ below low water. Two of the piers were protected with separate ice-breaker piers upstream to break or divert the floating ice and protect the bridge piers from damage (fig. 26). Four simple steel-through truss spans of $404 \mathrm{ft}, 305 \mathrm{ft}, 455 \mathrm{ft}$, and $405 \mathrm{ft}$, respectively, were placed on the piers from south to north. The total cost of the bridge when completed was $\$ 1,500,000$ and thus the bridge became known as the Million Dollar Bridge.

The Million Dollar Bridge was paved with an 18-foot wide concrete deck in 1961, when the railway was being converted to highway use. In 1964, during the Good Friday Earthquake, the 405-foot span on the north side of the bridge fell from its pier support to the river bottom where it rests today. Another pier was constructed near the damaged pier to support the remaining spans.

During the 1991 and 1992 water years, the average discharge of the Copper River was about $56,000 \mathrm{ft}^{3} / \mathrm{s}$. Suspended-sediment concentrations ranged from 528 to $2,210 \mathrm{mg} / \mathrm{L}$ (table 15 ). Particle-size analysis of selected samples indicates that most of the sediment is composed of silt and clay. Bedload sampling at this site is inconclusive: although the bedload sampler being used has not collected any material, this be may due to the limitation of the sampler. 


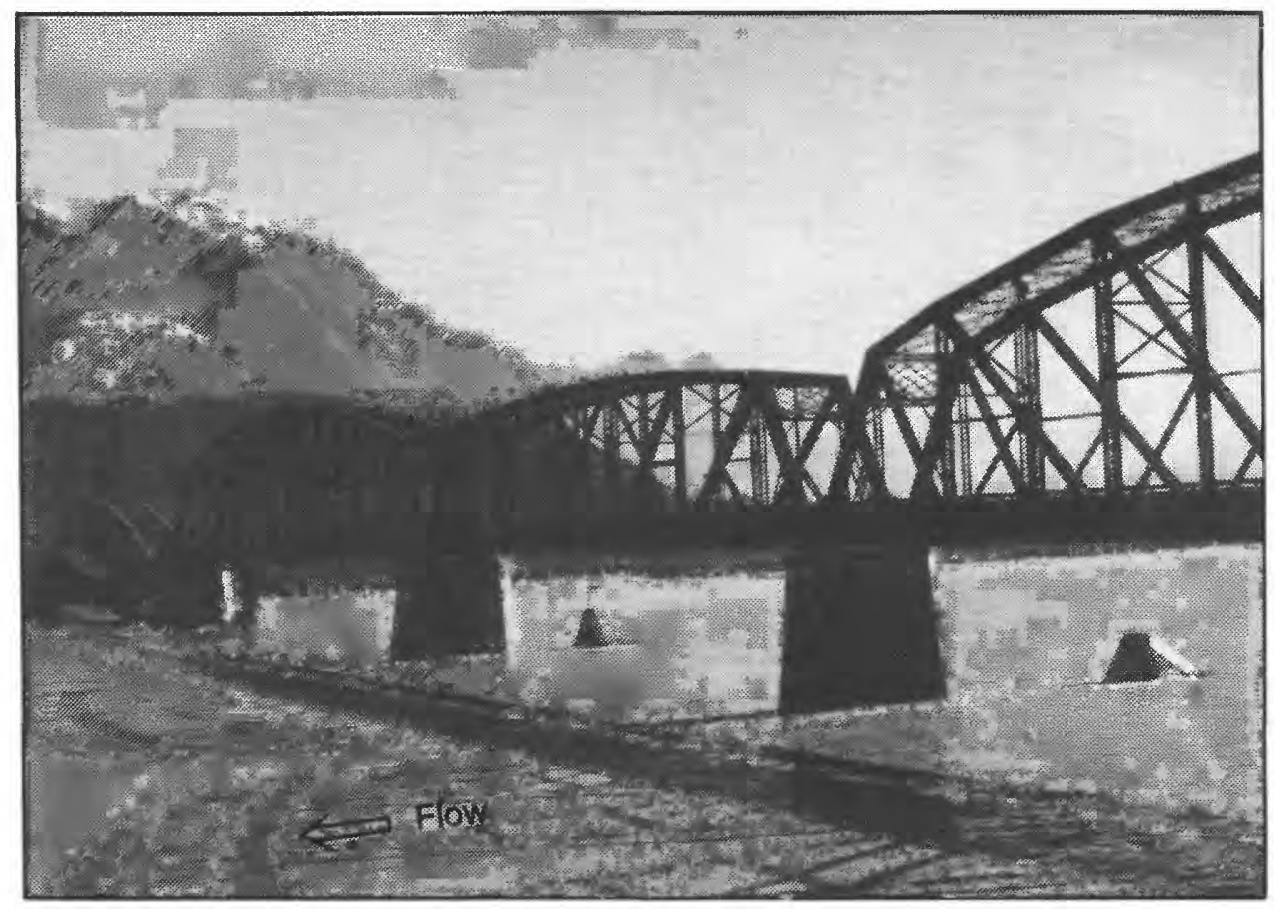

Figure 26. Million Dollar Bridge on the Copper River Highway, 1991.

In 1908, exploratory drilling at the Million Dollar Bridge site indicated $20 \mathrm{ft}$ of sand and loose gravel. Beyond $20 \mathrm{ft}$, the riverbed consisted of cemented sand, gravel, and boulders $\left(\mathrm{O}^{\prime} \mathrm{Neel}\right.$ and Hawkins, 1910). Pile-driving records from the 1975 bridge repair (when a support pier was installed) also indicated the presence of numerous large hard unweathered boulders nested in dense gravel. Because of this type of material, no significant scour or channel change at the site is expected.

Three discharge measurements were made at the upstream side of the Million Dollar Bridge in 1913. The next measurement was not made until 1978. From 1978, no measurements were made until 1988 when the gaging station was established. Measurements from 1978 to the present have been made at the same datum. Attempts were made to adjust the 1913 datum to the present datum, but no definitive relation could be determined. Thus, no corrections were made to the 1913 datum, but data from the first discharge measurement were still used to make some general observations.

Comparison of the cross sections taken at the Million Dollar Bridge in 1978, 1991, and 1992 (fig. 27) indicates that about $2 \mathrm{ft}$ of scour and fill has taken place. Some of these differences may be due to the inaccuracies of the various surveys. Comparing these cross sections with the cross section taken in 1913 indicates that the two main channels present in 1913 have remained relatively unchanged. Because the 1913 datum could not be adjusted to the current datum, it is uncertain whether scour or fill has occurred in these two channels. The area between pier 1 and pier 2 and the area near pier 3 appear to have scoured since 1913. However pier 3 was severely damaged in the 1964 earthquake and the changes in this area may be due to the earthquake or to the construction of the replacement pier. 


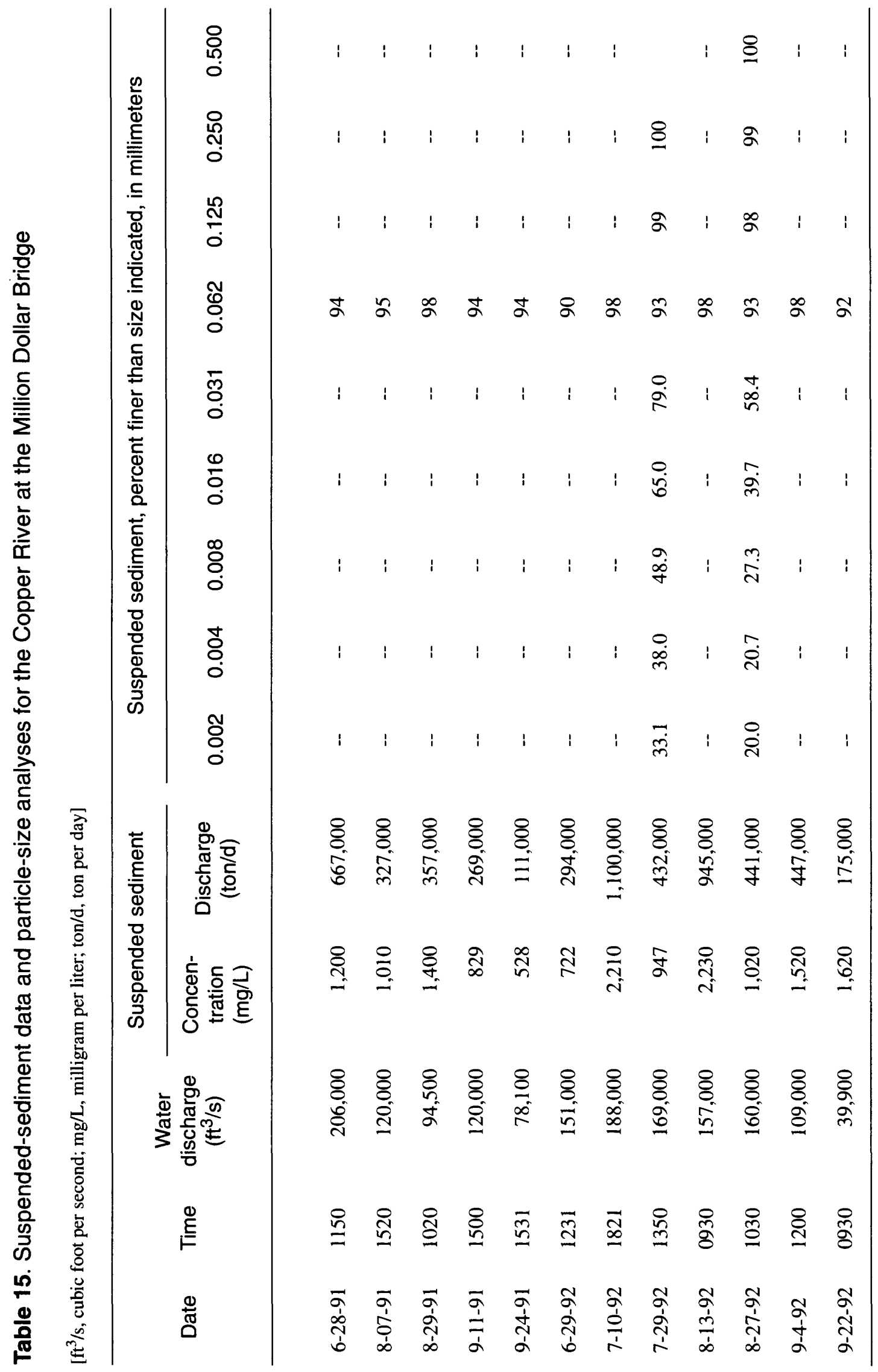




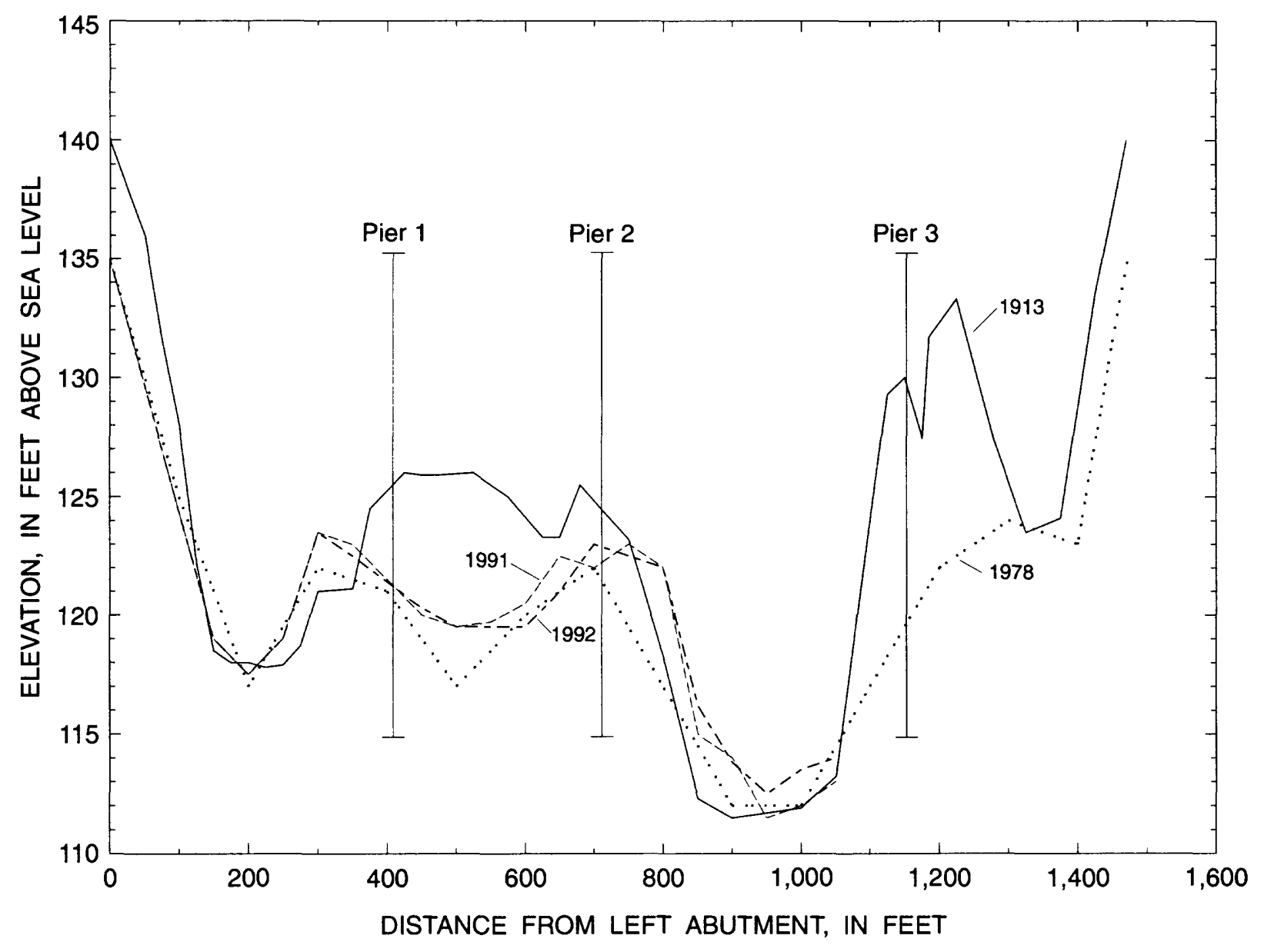

Figure 27. Cross sections of the Copper River, downstream side of the Million Dollar Bridge.

\section{SUMMARY AND CONCLUSIONS}

Scour characteristics at bridges along the Copper River Highway from Flag Point to the Million Dollar Bridge were studied. Principal findings of the study were:

- Significant scour has occurred at Bridge 331 between 1968 and 1992. Two distinct channels have formed at this bridge and the maximum local scour measured in 1992 was $6.5 \mathrm{ft}$.

- Some scour as well as some filling occurred at Bridge 1187, but the channel at this bridge has remained relatively unchanged between 1968 and 1992. The maximum local scour measured at this bridge in 1992 was $7.5 \mathrm{ft}$.

- Between 1968 and the beginning of 1992, the channel at Bridge 332 appears to have gradually filled. However, during 1992, significant scour occurred at the left side of the channel, lowering the mean bed elevation from 10.4 to $5.0 \mathrm{ft}$. The scour was probably due to a channel shift upstream from the bridge. 
- During 1991 and 1992, discharges measured at Bridges 333, 334, 336, 339, 340, 344, and 345 were less than 6 percent of the total flow past the Million Dollar Bridge. As a result, no significant scour was observed during this period at these sites. Between 1968 and 1991, scour had occurred at Bridges 333, 336, 339, 340, and 344, forming distinct channels at these sites.

- The various channels of the Copper River in the vicinity of Bridge 342 have undergone significant changes since 1968, with increasing quantities of flow directed towards this bridge. As a result, between 1982 and 1988, significant contraction scour occurred. The width of the bridge was increased in 1987. During 1991 and 1992, the channel approach to the bridge had begun to realign itself and as a consequence the right part of the channel at the bridge appears to have stabilized while the left part has scoured.

- Cross section surveys from 1978,1991 , and 1992 , indicate that minor or no scour has occurred at the Million Dollar Bridge, because of the size of the bed material and cemented nature of the alluvium.

- Equations that predict contraction and local scour were tested at Bridges 331 and 1187. The contraction scour equations overestimated the mean depth of flow at Bridge 331 from 2.6 to $5.0 \mathrm{ft}$, but were within $1.0 \mathrm{ft}$ in estimating the mean depth of flow at Bridge 1187. Equations that predict local scour gave varied results. For Bridge 331, equations using velocity directly as input gave relatively high values of predicted scour, possibly indicating that the velocity used did not represent the actual velocity upstream from the pier. In half the equations used for Bridge 1187, values of predicted scour were less than those of measured scour.

\section{REFERENCES CITED}

Anderson, A.G., 1974, Scour at bridge waterways--A review: Washington D.C., U.S. Federal Highway Administration RD-75-89, 29 p.

Bata, G., 1960, Scour around bridge piers: Institiut Za Vodoprivreder, Jaroslan Cerai Beozrad, Yugoslavia.

Blodgett, J.C., 1989, Monitoring scour at the State Route 32 bridge across the Sacramento River at Hamilton City, California, in Woo, D.C. and Fan, S.S., eds., Proceedings of the Bridge Scour Symposium: Washington, D.C., U.S. Federal Highway Administration RD-90-035, p. 211-226

Brabets, T.P., 1992, Hydrologic data for the lower Copper River, Alaska, May to September 1991: U.S. Geological Survey Open-File Report 92-89, 15 p.

1993, Hydrologic data for the lower Copper River, Alaska, May to September 1992: U.S. Geological Survey Open-File Report 93-162, 26 p.

Breusers, H.N.C., 1965, Scour around drilling platforms: International Association for Hydraulic Research, Bulletin of Hydraulic Research 1964 and 1965, v. 19, 276 p.

Carstens, M.R., 1966, Similarity laws for localized scour: American Society of Civil Engineers Proceedings, Journal of Hydraulics Division, v. 92, no. HY 3, p. 13-26.

Chitale, S.V., 1962, Discussion of scour at bridge crossings: American Society of Civil Engineers Transactions, v. 127, part 1, p. 191-196.

Cordova Times, 1983, Bridge problems may close highway: Cordova, Alaska, The Cordova Times, March $17,1983$. 
Edwards, T.K., and Glysson, G.D., 1988, Field methods for measurement of fluvial sediment: U.S. Geological Survey Open-File Report 86-531, 118 p.

Emmett, W.W., 1979, A field calibration of the sediment-trapping characteristics of the Helley-Smith bedload sampler: U.S. Geological Survey Open-File Report, 18 p.

Froehlich, D.C., 1988, Analysis of on-site measurements of scour at piers: American Society of Civil Engineers, 1988 National Conference on Hydraulic Engineering, Proceedings, 15 p.

Gorin, S.R., and Haeni, F.P., 1989, Use of surface-geophysical methods to assess riverbed scour at bridge piers: U.S. Geological Survey Water-Resources Investigations Report 88-4212, 33 p.

Helley, E.J., and Smith, W., 1971, Development and calibration of a pressure-difference bedload sampler: U.S. Geological Survey Open-File Report, 18 p.

Hopkins, G.R., Vance, R.W., and Kasraie, B., 1980, Scour around bridge piers: Washington, D.C., U.S. Federal Highway Administration RD-79-103, 131 p.

Jarrett, R.D., and Boyle, J.M., 1986, Pilot study for collection of bridge-scour data: U.S. Geological Survey Water-Resources Investigations Report 86-4030, 46 p.

Komura, Saburo, 1966, Equilibrium depth of scour in long constrictions: American Society of Civil Engineers Proceedings, Journal of Hydraulics Division, v. 92, no. HY 5, p. 17-38.

Landers, M.N., and Mueller, D.S., 1993, Reference surfaces for bridge scour depths: American Society of Civil Engineers, 1993 National Conference on Hydraulic Engineering, Proceedings, p. 2075-2080.

Lane, E.W., 1957, A study of the shape of channels formed by natural streams flowing in erodible material: U.S. Army Engineers Division, Missouri River Corps of Engineers.

Laursen, E.M., 1958, Scour at bridge crossings: Iowa Highway Research Board Bulletin 8, 53 p.

1962, Scour at bridge crossings: American Society of Civil Engineers Transactions, V. 127, part 1, p. 166-180.

Leopold, L.B., and Maddock, T., 1953, The hydraulic geometry of stream channels and some physiographic implications: U.S. Geological Survey Professional Paper 252, 56 p.

McIntosh, J.L., 1989, Use of scour prediction formulae, in Woo, D.C. and Fan, S.S., eds., Proceedings of the Bridge Scour Symposium: Washington, D.C., U.S. Federal Highway Administration RD-90-035, $380 \mathrm{p}$.

Molinas, A., and Santoro, V.C., 1989, BRI-STARS model and its applications, in Woo, D.C., and Fan, S.S., eds., Proceedings of the Bridge Scour Symposium: Washington, D.C., U.S. Federal Highway Administration RD-90-035, p. 256-271.

National Cooperative Highway Research Program, 1970, Scour at bridge waterways: National Research Board Synthesis of Highway Practice 5, 37 p.

Neill, C.R., 1964, Alluvial processes and river channel regime: Engineering Institute of Canada, Transactions, v. 7, no. A-3.

Norman, V.W., 1975, Scour at selected bridge sites in Alaska: U.S. Geological Survey Water-Resources Investigations 32-75, $160 \mathrm{p}$.

O’Neel, A.C., and Hawkins, E.C., 1910, Copper River and Northwestern Railway, Copper River Bridge near Miles Glacier: Engineers Report 1910,9 p.

Richardson, E.V., and Richardson, J.R., 1989, Bridge scour, in Woo, D.C., and Fan, S.S., eds., 1989, Proceedings of the Bridge Scour Symposium: Washington, D.C., U.S. Federal Highway Administration RD-90-035, p. 1-42. 
Richardson, E.V., Simons, D.B., Karaki, S., Mahmood, K., and Steven, M.A., 1975, Highways in the river environment: Fort Collins, Colo., U.S. Department of Transportation, Federal Highway Administration.

Richardson, E.V., Simons, D.B., and Julien, P.Y., 1988, Highways in the river environment (2d ed.): Fort Collins, Colo., U.S. Department of Transportation, Federal Highway Administration.

Richardson, J.R., and Price, J., 1993, Emergent techniques in scour monitoring devices: American Society of Civil Engineers, 1993 National Conference of Hydraulic Engineering, Proceedings, p. 1529-1533.

Shen, H.W., Schneider, V.R., and Karaki, S.S., 1969, Local scour around bridge piers: American Society of Civil Engineers, Journal of Hydraulics Division, v. 95, no. HY6, p. 1919-1940.

Straub, L.G., 1940, Approaches to the study of the mechanics of bed movement: Proceedings of Hydraulics Conference, University of Iowa Studies in Engineering, Bulletin 20.

Woo, D.C., and Fan, S.S., eds., 1989, Proceedings of the Bridge Scour Symposium: Washington, D.C., U.S. Federal Highway Administration RD-90-035, 380 p. 